Universidad de Lima

Escuela de Posgrado

Maestría en Tributación y Política Fiscal

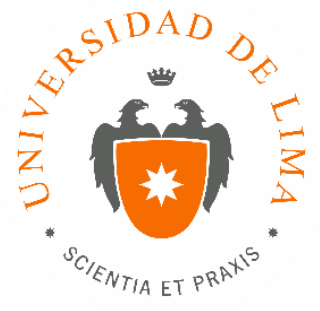

\title{
IMPLICANCIAS TRIBUTARIAS EN LA TRANSFERENCIA DE CARTERA CASTIGADA ENTRE EMPRESAS DEL SISTEMA FINANCIERO
}

Trabajo de investigación para optar el Grado Académico de Maestro en

Tributación y Política Fiscal

Rosa Mosqueira Torres

Código 20142493

Miguel Andrés Gargate Falcón

Código 20092045

Asesor: Roberto Cores Ferradas

$$
\text { Lima-Perú }
$$

Noviembre de 2017 


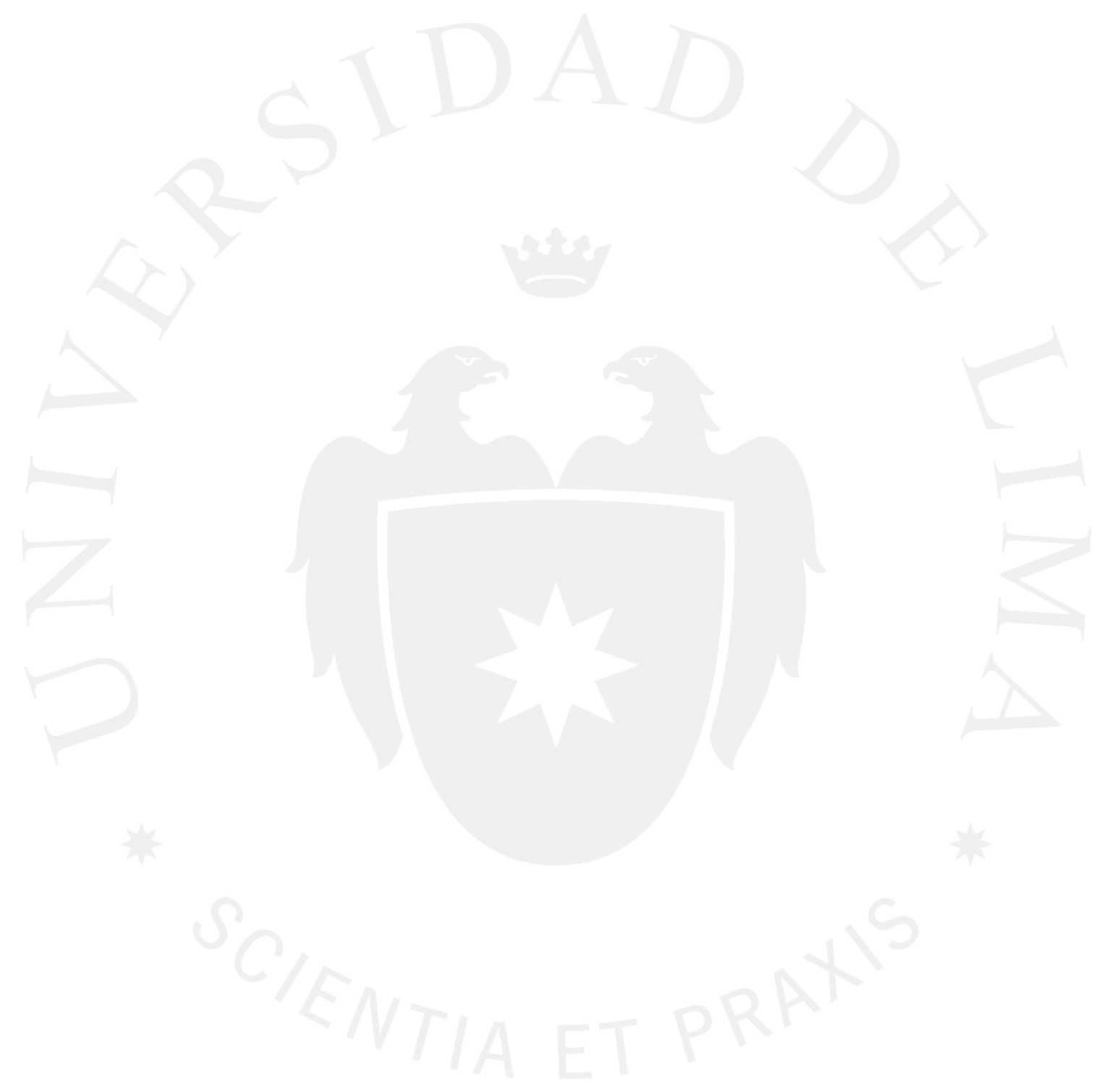




\section{IMPLICANCIAS TRIBUTARIAS EN LA TRANSFERENCIA DE CARTERA CASTIGADA ENTRE EMPRESAS DEL SISTEMA FINANCIERO}




\section{TABLA DE CONTENIDO}

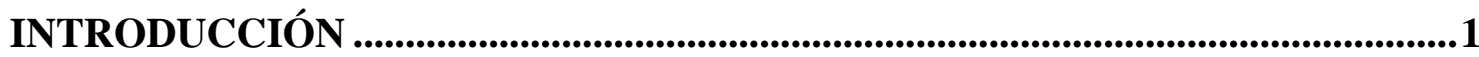

\section{CAPÍTULO I: PROVISIONES PARA CRÉDITOS Y DE COBRANZA DUDOSA}

\section{8}

1.1 Teoría y técnica del impuesto a la renta ................................................. 8

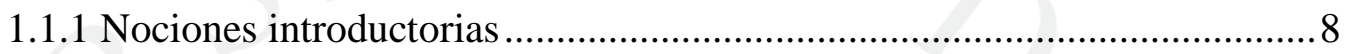

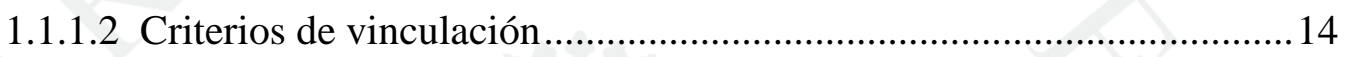

1.1.1.3 Aspecto temporal del impuesto a la renta......................................... 15

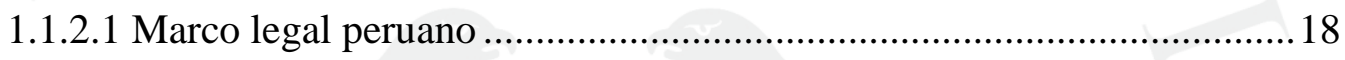

1.2 Provisiones para créditos y de cobranza dudosa .....................................20

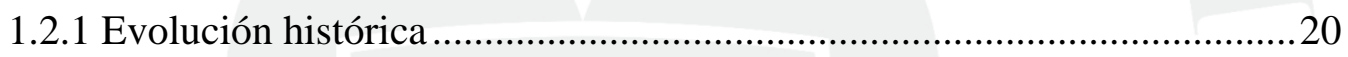

1.2.2Naturaleza contable de las provisiones para créditos de cobranza dudosa 27

1.2.2.1 Regulación pertinente de Superintendencia de Banca y Seguros ..........27

1.2.2.2. Dinámica contable sobre las provisiones de crédito y de cobranza dudosa.....

1.2.3Naturaleza tributaria de las provisiones para créditos y de cobranza dudosa

1.2.3.1. Regulación tributaria de las provisiones para créditos y colocaciones. 32

1.2.3.2 Regulación tributaria de las provisiones de cobranza dudosa.................. 35

CAPÍTULO II: CASTIGO DE CRÉDITOS INCOBRABLES ..................................39

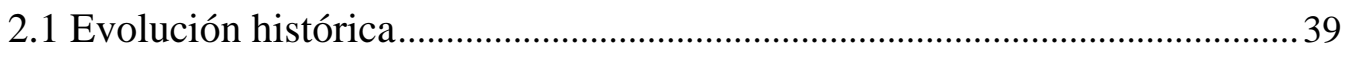

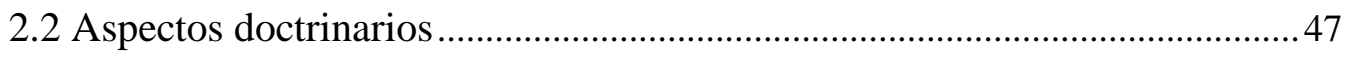

2.3 Regulación tributaria de los castigos de créditos ............................................50

2.4 Regulación pertinente de la Superintendencia de Banca y Seguros ..............54

2.5 Diferencia entre el tratamiento contable y tributario .....................................60 
2.6 Tratamiento en la legislación comparada .63

2.7 Posibles interpretaciones sobre el rol de los castigos .75

CAPÍTULO III: TRANSFERENCIA DE LA CARTERA CASTIGADA .80

3.1 Créditos en el derecho civil y en la doctrina .80

3.2 Regulación pertinente de la Superintendencia de Banca y Seguros .82

3.2.1. De los aspectos contables e información complementaria .84

3.3 Regulación tributaria de las transferencias de créditos .85

3.4 Determinación del valor nominal en la transferencia de crédito .88

CONCLUSIONES .95 


\section{ÍNDICE DE TABLAS}

Tabla 1.1: Evolución en el tratamiento de las provisiones de las empresas financieras.22

Tabla 2.1: Cuadro de legislación comparada en materia de deducción por deudas incobrables.. .66 


\section{ÍNDICE DE FIGURAS}

Figura 3.1: Implicancias de la Transferencia de Créditos . 


\section{INTRODUCCIÓN}

La presente investigación tiene como propósito determinar las implicancias tributarias de la transferencia de cartera castigada entre instituciones del sistema financiero y cuál debería ser el tratamiento óptimo a efectos de no generar distorsiones en el comportamiento de los agentes económicos por razones fiscales. Para ello se parte de las siguientes premisas:

1. Las empresas del sistema financiero a efectos de establecer la renta neta de tercera categoría pueden deducir i) las provisiones por cuentas por cobrar diversas, y ii) las provisiones ordenadas por la Superintendencia de Banca, Seguros y Administradora de Fondo de Pensiones (SBS) que cumplan con lo siguiente:

Sean autorizadas por el Ministerio de Economía y Finanzas, previa opinión técnica de la SUNAT, siempre que reunan los siguientes requisitos: (i) se trate de provisiones específicas; (ii) se trate de provisiones que no formen parte del patrimonio efectivo; y (iii) se trate de provisiones vinculadas exclusivamente a riesgos de crédito, clasificados en las categorías de problemas potenciales, deficiente, dudoso y pérdida (literal h) del artículo 37 del Decreto Supremo $N^{\circ}$ 179-2004-EF, Texto Único Ordenado de la Ley del Impuesto a la Renta, 2004).

En ese contexto, tanto el Texto Único Ordenado de la Ley del Impuesto a la Renta como el Decreto Supremo $\mathrm{N}^{\circ}$ 122-94-EF, Reglamento de la Ley del Impuesto a la Renta (1994), en adelante la LIR y su Reglamento, han establecido una regulación expresa para que las empresas del sistema financiero puedan deducir, para efectos tributarios, el gasto originado por la incobrabilidad de créditos y cuentas por cobrar diversas. Así pues, se reconoce un gasto cuando dichos activos han perdido su valor, ello con el propósito mantener la fuente productora de renta (el capital) que de otro modo se perdería.

Por otro lado, para efectos contables de lo que se trata es de ajustar el valor en libros del activo financiero cuando éste sea mayor a su importe recuperable estimado, de tal manera que se refleje en el balance general de las empresas el importe del activo que realmente se espera que genere beneficios económicos futuros. 
Al respecto, la NIC 32 define a los activos financieros, entre otros, como un derecho contractual a recibir efectivo u otro activo financiero de otra entidad. Agrega que son ejemplos comunes de activos financieros: (a) cuentas por cobrar y por pagar de origen comercial; (b) pagarés por cobrar y por pagar; (c) préstamos por cobrar y por pagar; y (d) obligaciones o bonos por cobrar y por pagar.

Los activos referidos en el párrafo anterior como todo activo en general, son susceptibles de disminución en su valor, generándose provisiones contables. Así lo reconoce por ejemplo la NIC 39 al señalar que

(c)uando exista evidencia objetiva de que se ha incurrido en una pérdida por deterioro del valor en activos financieros medidos al costo amortizado, el importe de la pérdida se medirá como la diferencia entre el importe en libros del activo y el valor presente de los flujos de efectivo futuros estimados

Siendo que "(e)l importe en libros del activo se reducirá directamente, o mediante una cuenta correctora” y “(e)l importe de la pérdida se reconocerá en el resultado del periodo". (El subrayado es nuestro)

En ese sentido, cuando se registran estas provisiones contables, dicho importe incide tanto en la determinación de la utilidad contable como en la deducción del costo del activo financiero. Siendo ello así, si este gasto cumpliera a su vez con los requisitos establecidos en las normas tributarias, disminuirá la renta neta imponible como el costo del activo financiero.

Este análisis será tocado en el capítulo I, donde es importante notar que tanto para efectos contables como tributarios, lo que se generó es un gasto que reduce la renta neta imponible y un descuento al valor nominal de dichos créditos; con lo cual, bajo el supuesto que la provisión fue realizada en su integridad, el valor nominal de dichos créditos a esa fecha seria igual a cero.

2. Como segundo punto nos abocaremos a indagar sobre el rol de los castigos en la contabilidad y la tributación. Ahora bien, considerando que ni la LIR ni su Reglamento han definido qué debe entenderse por "castigo" de deudas incobrables, resulta pertinente recurrir a la definición establecida por la SBS en su glosario de términos e indicadores financieros, el mismo que señala que los créditos castigados son 
aquellos clasificados como pérdida, íntegramente provisionados, que han sido retirados de los balances de las empresas.

Así pues, al efectuar el castigo de un activo financiero, como es el caso de las colocaciones y/o cuentas por cobrar, contablemente intervienen en su dinámica, un cargo a la cuenta de activo por la estimación que originó el deterioro y un abono al activo financiero original por el mismo importe, que al netearse generan la desaparición del activo del Balance General.

Nótese de lo expuesto, que contablemente el castigo no es una operación que afecte los resultados del ejercicio -que a su vez originarían una disminución en la renta neta de tercera categoría-, sino por el contrario es una eliminación del activo financiero devaluado dentro del Balance General; situación diferente a lo que ocurre en las provisiones de cobranza dudosa que sí generan un gasto y por lo tanto una disminución de la renta neta imponible.

Bajo ese contexto nos preguntamos porque la LIR y su Reglamento, establecen requisitos y considera que existe un "gasto" con el hecho de realizar el castigo de las provisiones de cobranza dudosa, realizadas en un ejercicio posterior, cuando el verdadero gasto se contabilizó previamente con la provisión de cobranza dudosa.

De lo expuesto, se plantean 3 posibles interpretaciones sobre la función del castigo en la tributación del impuesto a la renta:

a) Los castigos no tienen incidencia en la determinación del impuesto a la renta toda vez que la operación que afectó dicha determinación es la constitución de provisiones por deudas incobrables. En ese sentido tributariamente resulta irrelevante el cumplimiento de los requisitos del castigo.

b) Tanto las provisiones como los castigos son deducibles en la determinación del impuesto a la renta. Dentro de esta posible lectura la forma de deducción de provisiones y castigo podrían presentar distintos matices que veremos más adelante.

c) Finalmente también podría interpretarse que cuando la norma exige el cumplimiento de ciertos requisitos para el castigo, lo que podría estar buscando es que, a manera de doble filtro, no se pierda el control tributario de las cuentas que lo originan, de tal manera que si en un futuro se procediera con su recuperación se pueda establecer la correlación entre los conceptos que formaron 
su provisión. Con lo cual, no se puede concluir que se deba adicionar un gasto, ya que como se explicó, no existe tal provisión en dicho ejercicio, y menos aún que el activo financiero vuelva a tener contenido económico, pues es indiscutible que la disminución de su valor se dio al momento de la provisión y no en un momento posterior como es el castigo

3. En lo que se refiere al objeto de nuestro estudio cabe advertir que reglamentariamente se ha establecido que las empresas del sistema financiero para efectuar el castigo de la provisión de cobranza dudosa del activo financiero (colocaciones y/o cuentas por cobrar), requieren que el Directorio declare la inutilidad de iniciar las acciones judiciales correspondientes. Este acuerdo deberá ser ratificado por la SBS, mediante una constancia en la que certifique que las empresas del sistema financiero han demostrado la existencia de evidencia real y comprobable sobre la irrecuperabilidad de los créditos que serán materia del castigo.

En efecto, las normas reglamentarias señalan que el castigo de las deudas provisionadas por colocaciones y/o cuentas por cobrar, cuyos montos exigibles superen de 3 UIT por cada deudor, sólo surtirá efecto, cuando las empresas del sistema financiero cuenten con la referida Constancia. Dicha Constancia de Irrecuperabiidad deberá ser emitida dentro del plazo establecido para la presentación de la declaración jurada anual del ejercicio al que corresponda el castigo o hasta la fecha en que la empresa hubiera presentado dicha declaración, lo que ocurra primero. De no emitirse la constancia en los referidos plazos, no procederá el castigo.

Nótese que la controversia radica justamente en el cumplimiento del requisito formal de contar con la Constancia de Irrecuperabilidad, y el efecto que ocasionaría en la determinación de la renta neta imponible de las empresas del sistema financiero; ya que de no emitirse la constancia en el referido plazo $\left({ }^{1}\right)$, no procederá su posterior emisión, toda vez, que la norma expresamente lo prohíbe, volviéndose en los hechos, un requisito de naturaleza insubsanable.

1 Considerar que dicho plazo fue ampliado a través del Decreto Supremo N $134-2004-E F$, -donde el reglamentador tuvo la oportunidad de revisar el tema -, que a decir de la exposición de motivos sólo considero pertinente ampliar el plazo de su emisión, hasta el vencimiento para la presentación de la declaración anual del Impuesto a la Renta. 
Sin embargo, es innegable que en la actualidad tenemos una regulación reglamentaria expresa para el castigo de las deudas de cobranza dudosa, es por ello que, dependiendo de la lectura que se le confiera al rol de los castigos en el impuesto a la renta, una de las cuestiones a desarrollar, sería que si el hecho de no contar con la Constancia de Irrecuperabilidad que exige el Reglamento de la LIR, para las empresas del sistema financiero, generaría o no una adición, en la declaración jurada anual del ejercicio en el cual se contabilizó dicho castigo, y si esta norma vulneraría el principio de legalidad.

A mayor abundamiento, podemos indicar que existe una corriente interpretativa que sostiene que los gastos por provisiones para créditos y de cobranza dudosa tendrían que pasar por un doble filtro para efectos de su deducción, esto es, el primer filtro sería el que le asiste por su propia naturaleza como provisión del gasto, y el segundo filtro implicaría cumplir con los requisitos del castigo; por ello, su incumplimiento generaría una adición en la declaración jurada por el importe del gasto registrado en un ejercicio anterior.

En línea a esta corriente, se generan interrogantes sobre el destino del gasto adicionado, ¿dicho gasto genera una diferencia temporal o permanente? -considerando que en la práctica es un requisito insubsanable por haber transcurrido el plazo para que la SBS emita la Constancia de Irrecuperabilidad- $\left({ }^{2}\right)$. De ser una diferencia permanente, nos consultamos si ¿puede acaso un requisito formal establecido en un Reglamento, hacer perder el derecho al gasto, que por Ley fue correctamente deducido en un ejercicio anterior?

Otro efecto no deseado, que podría derivarse de dicha interpretación es que las empresas del sistema financiero podría optar por la transferencia de dichos créditos y no por el cumplimiento de los requisitos del castigo, uno por ser menos oneroso y otro por ser una diferencia insubsanable.

En tal sentido, una segunda hipótesis a desarrollar, es que al haberse adicionado el gasto de las provisiones para créditos y de cobranza dudosa contabilizadas en un ejercicio anterior, ocasionaría que para efectos tributarios, el valor nominal de los

2 Considerando que el Reglamento de Renta señala a la letra lo siguiente: "La referida constancia será emitida dentro del plazo establecido para la presentación de la declaración jurada anual del ejercicio al que corresponda el castigo o hasta la fecha en que la empresa hubiera presentado dicha declaración, lo que ocurra primero. De no emitirse la constancia en los referidos plazos, no procederá el castigo". (el subrayado es nuestro). 
citados créditos retorne a su costo original, es decir, implicaría extornar la operación como si ésta nunca se hubiera realizado restituyendo su monto original, con ello si en una futura operación, como por ejemplo una venta, el activo financiero adquiriría valor nominal para todo efecto tributario.

4. En definitiva, se ha notado en los últimos años, casos en los cuales las empresas del sistema financiero han celebrado contratos de compra o de venta de cartera previamente castigada, en este supuesto, para efectos tributarios, cuando se transfiere créditos donde el adquiriente asume el riesgo crediticio del deudor, la diferencia entre el valor nominal del crédito y el valor de transferencia constituye concepto deducible para el transferente del crédito. Cabe mencionar que el valor nominal del crédito transferido está representado por el costo del activo financiero.

5. Ahora bien, bajo la primera lectura el rol del castigo en el impuesto a la renta, es decir que este es irrelevante para su determinación, cuando se efectúe transferencia de cartera castigada, como se tratan de activos íntegramente provisionados, el costo computable de los créditos correspondientes a colocaciones y cuentas por cobrar al momento de la provisión equivaldría a "cero"; por lo tanto, no existiría valor nominal del crédito que descuente el valor de transferencia.

Técnicamente, si el contribuyente deduce íntegramente el valor nominal de los créditos (colocaciones y/o cuentas por cobrar) cuando registró la provisión de incobrabilidad no resulta razonable que nuevamente se reconozca el valor nominal del activo financiero al momento en que realice su transferencia, puesto que ello implicaría deducir doblemente el mismo concepto, esto es, el costo del activo financiero.

La situación sería diferente, cuando, bajo la tercera lectura del rol del castigo, la línea de interpretación sería adicionar el gasto de la provisión de cobranza dudosa -por no contar con la Constancia de Irrecuperabilidad-; en estos casos, como se indicó líneas arriba el costo del activo financiero se restituye lo que ocasiona que, al momento de realizar la transferencia de los créditos en estado de castigo, la diferencia entre el valor nominal del crédito y el valor de transferencia constituiría un concepto deducible a efectos de determinar la renta neta imponible; recuperándose en ese momento el gasto previamente adicionado por no cumplir con los requisitos reglamentarios del castigo. 
6. De lo reseñado hasta este punto no queda claro el rol que cumple el castigo de créditos por colocaciones y/o cuentas por cobrar dentro de la legislación tributaria, y las consecuencias que pueden derivar cuando se transfiera la cartera castigada a un tercero.

Por ello, en el presente trabajo haremos notar las deficiencias y vacíos que presenta la legislación peruana, que ha conllevado a un sector importante del país a transferir su cartera castigada a terceros o vinculados, con la finalidad de hacer deducible el valor nominal de los créditos vía este mecanismo, y con ello evitar cumplir con los requisitos especiales que le asiste por su naturaleza.

En el desarrollo del siguiente trabajo utilizaremos las siguientes abreviaturas:

- Texto Único Ordenado de la Ley del Impuesto a la Renta, aprobado por el Decreto Supremo $\mathrm{N}^{\circ}$ 179-2004-EF, publicado el 8.12.2004 y normas modificatorias, en adelante "la LIR".

- Reglamento de la Ley del Impuesto a la Renta, aprobado por el Decreto Supremo $\mathrm{N}^{\circ}$ 122-94-EF, publicado el 21.9.1994, y normas modificatorias en adelante "Reglamento de la LIR".

- Ley $\mathrm{N}^{\circ}$ 26702, Ley General del Sistema Financiero y del Sistema de Seguros y Orgánica de la Superintendencia de Banca y Seguros, publicada el 9.12.1996, y normas modificatorias, en adelante "Ley General del Sistema Financiero".

- Ley General de Sociedades, aprobado por la Ley N$^{\circ} 26887$, publicada el 9.12.1997, en adelante "LGS".) 


\section{CAPÍTULO I: PROVISIONES PARA CRÉDITOS Y DE COBRANZA DUDOSA}

\subsection{Teoría y técnica del impuesto a la renta}

\subsubsection{Nociones introductorias}

\subsubsection{El impuesto a la renta y las teorías que recogen su aplicación}

El impuesto a la renta se configura como un tributo directo, de carácter natural y subjetivo, aplicable en muchos países, que grava la utilidad de las personas, empresas, u otras entidades legales. Sobre este tema, Jorge Bravo Cucci (2002) menciona que:

El impuesto a la renta es un tributo que se precipita directamente sobre la renta como manifestación de riqueza. En estricto, dicho impuesto grava el hecho de percibir o generar renta, la cual puede generarse de fuentes pasivas (capital), de fuentes activas (trabajo dependiente o independiente) o de fuentes mixtas (realización de una actividad empresarial $=$ capital + trabajo). En tal secuencia de ideas, es de advertir que el impuesto a la renta no grava la celebración de contratos, sino la renta que se obtiene o genera por la instauración y ejecución de las obligaciones que emanan de un contrato y que en el caso de las actividades empresariales, se somete a tributación neta de gastos y costos relacionados a la actividad generadora de renta.

Así pues, el hecho imponible del impuesto a la renta es un hecho jurídico complejo (no un acto o un negocio jurídico) con relevancia económica, que encuentra su soporte concreto, como ya lo hemos indicado, en la manifestación de riqueza directa denominada "renta" que se encuentra contenido en el aspecto material de su hipótesis de incidencia, pero que requiere de la concurrencia de los otros aspectos de la misma, vale decir el personal, el espacial y el temporal, para calificar como gravable. En esa secuencia de ideas, resulta importante advertir que el hecho imponible del impuesto a la renta se relaciona con los efectos del contrato, y no con el contrato ensimismo. (pp.63$64)$. 
Ahora bien, para establecer qué debe entenderse por renta existen básicamente tres teorías en la doctrina (i) de la renta producto, (ii) del consumo más incremento patrimonial, y (iii) del flujo de riqueza, las cuales pasamos a explicar a continuación:

\section{A) TEORIA DE RENTA PRODUCTO}

García Mullín (1980) señala que este criterio, en el cual subyace una concepción de la renta de tipo económico y objetivo, entiende que es tal "el producto periódico que proviene de una fuente durable en estado de explotación". (p. 17)

Por consiguiente, sólo son categorizables como rentas, los enriquecimientos que llenen estos requisitos:

- Sean un producto $\left(^{3}\right)$,

- Provengan de una fuente durable $\left({ }^{4}\right)$,

- Sean periódicos $\left({ }^{5}\right), \mathrm{y}$,

- La fuente haya sido puesta en explotación (habilitación) $\left({ }^{6}\right)$.

A tenor de nuestra legislación, la teoría de la fuente o renta producto está recogida en el literal a) del artículo $1^{\circ}$ de la LIR, que señala que el impuesto a la renta grava las rentas que provengan del capital, del trabajo y de la aplicación conjunta de ambos factores,

La renta debe ser un producto, es decir, una riqueza nueva, distinta y separable de la fuente que la produce. Por ello, no es renta, en esta concepción, el mayor valor que experimente un bien, ni el crecimiento operado en un bosque, etc. (García Mullín, 1980, p. 18).

4 Por fuente productora se entiende un capital, corporal o incorporal, que teniendo un precio en dinero, es capaz de suministrar una renta a su poseedor. En ese concepto entran básicamente las cosas muebles o inmuebles, los capitales monetarios, los derechos y las actividades. La fuente para ser tal debe ser durable, en el sentido de que sobreviva a la producción de la renta, manteniendo su capacidad para repetir en el futuro ese acto. Lo importante del concepto radica en que excluye la consideración como renta de las ganancias de capital, pues en ellas, la fuente se agota (para la persona) en el momento en que la ganancia se realiza. (García Mullín, 1980, pp. 18-19).

5 Coma consecuencia del carácter durable de la fuente, y vinculado a él, se afirma la necesaria periodicidad de la renta. Pero es importante destacar que no es necesario que la periodicidad se concrete en los hechos (es decir, que realmente se repita la renta), sino que basta con que sea posible. El concepto de periodicidad se conforma, así, con la simple potencialidad o posibilidad, la que se presenta cuando la fuente tiene la capacidad de volver a repetir el producto, si es nuevamente habilitada a tal efecto. ((García Mullín, 1980, p. 19).

6 A efectos de producir renta, es necesario que la fuente haya sido habilitada racionalmente para ello o sea afectada a destinos productores de renta. (García Mullín, 1980, p. 19). 
entendiéndose como tales aquellas que provengan de una fuente durable y susceptible de generar ingresos periódicos.

Añade la norma, que están incluidas dentro de las rentas previstas en el inciso a), las siguientes:

1) Las regalías.

2) Los resultados de la enajenación de:

(i) Terrenos rústicos o urbanos por el sistema de urbanización o lotización.

(ii) Inmuebles, comprendidos o no bajo el régimen de propiedad horizontal, cuando hubieren sido adquiridos o edificados, total o parcialmente, para efectos de la enajenación.

3) Los resultados de la venta, cambio o disposición habitual de bienes.

Dentro de la teoría renta producto cabe resaltar lo señalado por la doctrina en relación a la durabilidad de la fuente. Al respecto Allix y Lecercle señalan que no hay fuente que no se extinga a la larga, aunque ellas pueden ser más o menos durables ya que en la producción de los frutos siempre hay una parte de la fuente que se altera disminuyendo o desapareciendo. En ese sentido se admite la necesidad de deducir de la renta bruta la amortización, para asegurar, mediante la puesta en reserva de una fracción anual del beneficio, el reemplazo de la fuente cuando ella este fuera de uso (como se citó en García Belsunce, 1967, p. 100).

Los créditos serían una excepción a esta regla porque al término del préstamo el capital permanece intacto. Esto que en principio es cierto cuando se devuelve el préstamo o se pagan las deudas deja de serlo cuando los créditos se vuelven incobrables y en ese sentido creemos que a efectos de mantener la fuente se debe admitir la deducción de incobrables.

\section{B) TEORIA DE FLUJO DE RIQUEZA}

Al respecto, García Mullín (1980) señala que otro criterio tributario más amplio que el antes analizado (renta producto), considera renta la totalidad de esos enriquecimientos 
provenientes de terceros, o sea al total del flujo de riqueza que desde los terceros fluye hacia el contribuyente, en un periodo dado (p. 20).

A decir de García Mullín(1980):

Este criterio engloba todas las rentas categorizables como renta producto. Pero al no exigir que provenga de una fuente productora durable, ni importar su periodicidad, abarca una serie más de ingresos que seguidamente se indican:

- Las ganancias de capital realizadas $\left({ }^{7}\right)$,

- Los ingresos por actividades accidentales $\left({ }^{8}\right)$,

- Los ingresos eventuales $\left({ }^{9}\right), \mathrm{y}$

- Los ingresos a título gratuito $\left({ }^{10}\right)$,

Como se puede apreciar, se advierte que en aplicación de esta teoría se considera como condición suficiente y a la vez necesaria para configurar la renta, el hecho de tratarse de enriquecimientos que han fluido desde terceros hacia el contribuyente, independientemente de que sean producto o no de fuente alguna (p. 20-21).

En lo que respecta al impuesto a la renta, la teoría de flujo de riqueza se encuentra en los literales b) y c) del artículo $1^{\circ}$ de la LIR que dispone que dicho impuesto grava, las ganancias de capital y otros ingresos que provengan de terceros, establecidos por la LIR, respectivamente.

Por su parte, el artículo $2^{\circ}$ de la LIR señala que para efectos del impuesto a la renta:

Constituye ganancia de capital cualquier ingreso que provenga de la enajenación de bienes de capital. Se entiende por bienes de capital a aquellos que no están

7 Se consideran tales, las originadas en la realización de bienes patrimoniales, en tanto la realización de esos bienes no sea el objeto de una actividad lucrativa habitual. (García Mullín, 1980, p. 21).

8 Son ingresos originados por una habilitación transitoria y eventual de una fuente productora, o sea que provienen de actos accidentales que no implican una organización de actividades con el mismo fin. (García Mullín, 1980, p. 21).

9 Son ingresos cuya producción depende de un factor aleatorio, ajeno a la voluntad de quien lo obtiene, tales como los premios de lotería y los juegos de azar. No hay periodicidad ni habilitación racional de fuente, de modo que no podrían caber en el concepto de renta producto. (García Mullín, 1980, p. 21) .

10 Comprende tanto a las transmisiones gratuitas por acto entre vivos (regalos, donaciones) coma las por causa de muerte (legados y herencias). (García Mullín, 1980, p. 21). 
destinados a ser comercializados en el ámbito de un giro de negocio o de empresa.

Asimismo, el penúltimo párrafo del artículo $3^{\circ}$ de la LIR señala que, en general, constituye renta gravada de las empresas, cualquier ganancia o ingreso derivado de operaciones con terceros, así como el resultado por exposición a la inflación determinado conforme a la legislación vigente.

En ese aspecto, el inciso g) del artículo $1^{\circ}$ del Reglamento de la LIR indica lo siguiente:

Que la ganancia o ingreso derivado de operaciones con terceros a que alude el penúltimo párrafo del artículo $3^{\circ}$ de la LIR, se refiere a la obtenida en el devenir de la actividad de la empresa en sus relaciones con otros particulares, en las que los intervinientes participan en igualdad de condiciones y consienten el nacimiento de obligaciones.

Agrega dicho inciso que, en consecuencia, constituye ganancia o ingreso para una empresa, la proveniente de actividades accidentales, los ingresos eventuales y la proveniente de transferencias a título gratuito que realice un particular a su favor. En estos casos, el adquirente deberá considerar la ganancia o ingreso al valor de ingreso al patrimonio.

En ese sentido el informe $\mathrm{N}^{\circ}$ 0146-2015-SUNAT/5D0000 de la SUNAT en relación a las teorías de renta que informan nuestra legislación sobre el impuesto a la renta ha concluido que:

Conforme fluye de las normas citadas, el impuesto a la renta considera como rentas gravadas, entre otras, a las que responden al criterio de renta-producto, vale decir, a las que provienen de una fuente durable y susceptible de generar ingresos periódicos; así como a las ganancias consideradas dentro del criterio de flujo de riqueza que asume nuestra legislación del impuesto a la renta, una de cuyas características es que para que la ganancia o ingreso derivado de operaciones con terceros califique como renta gravada debe ser obtenida en el devenir de la actividad de la empresa en sus relaciones con otros particulares, en las que los intervinientes participan en igualdad de condiciones y consienten el nacimiento de obligaciones (2015). 


\section{C) CRITERIO DE CONSUMO MAS INCREMENTO DE PATRIMONIO}

Sobre esta teoría García Mullín (1980) señala que:

Esta doctrina supone un concepto de renta que tiene su centro en el individuo y busca captar la totalidad de su enriquecimiento (capacidad contributiva) a lo largo de un periodo.

Podría decirse que en la concepción de renta producto, el énfasis se coloca sobre el fenómeno de producción y el eje de la imposición está en la consideración objetiva de que una fuente produce; y que en el criterio del flujo de riqueza, la consideración más relevante es la del tránsito patrimonial desde los terceros al perceptor. En este criterio, en cambio, el individuo es el gran protagonista; las satisfacciones de que dispone, a lo largo de un periodo, son el test último de su capacidad contributiva fiscal.

Esas satisfacciones, en definitiva, tienen dos formas de manifestarse: o se transforman en consumo o terminan incrementando el patrimonio al fin del periodo. Por eso, la suma algebraica de lo consumido más los cambios en el valor del patrimonio, constituyen la renta del período.

Como se ve en este enfoque, para nada interesa saber si la renta fue producto de fuente o no; ni siquiera interesa saber si provino de un flujo de riqueza desde terceros.

Además de esos rubros la renta, como corriente de satisfacciones, puede haber consistido en el consumo de bienes o servicios producidos por el mismo individuo o en el consumo de bienes durables adquiridos con anterioridad o en simples variaciones de valor que ha experimentado el patrimonio, por cualquier causa que sea, entre el comienzo y el fin del periodo y aunque no se haya "realizado" mediante una operación de mercado con terceros (p. 22-23).

Siguiendo con la analogía que se está realizando con el impuesto a la renta podríamos indicar que esta teoría se encuentra dentro del inciso d) del artículo $1^{\circ}$ de la LIR dispone que dicho impuesto grava, las rentas imputadas, incluyendo las de goce o disfrute, establecidas por esta LIR. 


\subsubsection{Criterios de vinculación}

Los criterios de vinculación del impuesto a la renta definen el derecho de un Estado a imponer su sistema tributario sobre operaciones que considera dentro de su ámbito jurisdiccional.

En efecto, para que un enriquecimiento calificado abstractamente como "renta" por una legislación genere el impuesto correspondiente, es necesario que tenga algún tipo de conexión o vinculación con el país, esto es, que el Estado se atribuya jurisdicción en el sentido de potestad tributaria para hacer tributar ese fenómeno a sus arcas(García Mullín, 1980, p. 45).

De acuerdo a la doctrina fiscal internacional, son dos los criterios básicos de vinculación que se reconocen en el ámbito de las relaciones fiscales internacionales (Rubio Guerrero, 2001, pp. 42-43):

- Criterio personal o subjetivo: Implica la sujeción al gravamen de toda la renta mundial de un residente, domiciliado o nacional de un país determinado con independencia de la localización de la fuente productora de la renta.

- Criterio territorial u objetivo: También conocido como el principio de la fuente u origen de la renta, implica la sujeción a gravamen de los residentes y no residentes de las rentas cuyas fuentes están localizadas en el país que pretende imponer su sistema tributario.

Como ha sido reconocido en la práctica fiscal internacional, ambos criterios se aplican de manera combinada.

A tenor de nuestra legislación tributaria, se incorpora ambos criterios de vinculación en el artículo $6^{\circ}$ de la LIR, que establece lo siguiente:

Están sujetas al impuesto la totalidad de las rentas gravadas que obtengan los contribuyentes que, conforme a las disposiciones de ley, se consideran domiciliados en el país, sin tener en cuenta la nacionalidad de las personas naturales, el lugar de constitución de las jurídicas, ni la ubicación de la fuente productora. Añade dicho artículo, que en caso de contribuyentes no domiciliados en el país, de sus sucursales, agencias o establecimientos permanentes, el impuesto recae sólo sobre las rentas gravadas de fuente peruana. 
Por otro lado, los artículos $9^{\circ}, 10^{\circ}$ y $11^{\circ}$ establecen otros supuestos de generación de renta de fuente peruana que, en principio, estará gravado con el impuesto a la renta, salvo que exista una inafectación legal o una exoneración.

\subsubsection{Aspecto temporal del impuesto a la renta}

Como hemos visto hasta este punto el impuesto a la renta es un tributo que grava una manifestación de riqueza expresada por una persona, natural o jurídica, a través de la renta obtenida. Independientemente de la teoría que se utilice para determinar cuál es la renta que una persona obtiene, lo ideal sería gravar dicha manifestación una sola vez, es decir tomando en cuenta toda la renta producto, ganancia de capital o incremento patrimonial más consumo obtenido por una persona durante toda su vida. Sólo así podría determinarse cuál es la verdadera capacidad contributiva que tiene una persona en forma integral y completa.

Ahora bien, como el fisco requiere ingresos periódicos como regla general se acepta que la determinación del impuesto a la renta se haga por ejercicios anuales. En ese sentido también se ha pronunciado el Tribunal Fiscal, mediante RTF $N^{\circ}$ 9518-22004 en la que se señala que la generación de renta en toda empresa es un hecho constante, pero para efecto del impuesto a la renta las rentas obtenidas deben ser medidas en un periodo o ejercicio determinado.

Un primer problema de la medición de la renta por periodos es la adopción de un criterio de imputación ya sea bajo el criterio de lo devengado o de lo percibido y lo que debe entenderse por tales conceptos. Así bajo el criterio de lo devengado las rentas se imputan a determinado ejercicio cuando se ganan y no cuando se percibe el ingreso. Bajo el criterio de lo percibido las rentas se imputan al ejercicio en que efectivamente se perciban o estén a disposición del beneficiario. Del mismo modo, bajo el criterio del devengado los gastos se pueden deducir ya sea cuando se incurran, es decir cuando surja la respectiva obligación aunque no se hayan pagado o, bajo el criterio de lo percibido, cuando efectivamente se paguen. Nuestra legislación del impuesto a la renta empresarial ha optado por el criterio de lo devengado, salvo puntuales excepciones como el "interés en suspenso", y aunque en principio parece sencillo, la aplicación de dicho criterio ha sido objeto de diversas controversias entre los contribuyentes y la Administración Tributaria siendo que la jurisprudencia del Tribunal Fiscal ha 
evolucionado en el transcurso de los años; no obstante ello, no entraremos a mayor detalle por no ser objeto del presente trabajo.

En lo que respecta a las deducciones por créditos o deudas incobrables, no queda claro cómo se materializaría la adopción del criterio del devengado o del percibido, sin embargo, siendo que las NIIFs, en general, se informan bajo la hipótesis de lo devengado estas deducciones por incobrabilidad deberían ser deducibles en el ejercicio en que exista evidencia objetiva de que se ha incurrido en una pérdida por dicho concepto (NIC 39) y no cuando efectivamente esta pérdida se materialice.

Cuando revisemos la legislación comparada veremos que existen diversos matices en relación al momento del reconocimiento de las deducciones por créditos o deudas incobrables.

De lo referido hasta este punto puede concluirse que un activo financiero tal como un crédito y otras cuentas por cobrar constituyen una fuente productora de renta bajo la teoría de renta producto acogida en nuestra legislación. Por lo tanto, las pérdidas por la irrecuperabilidad de los créditos se admiten como gasto pues se acepta que parte de los beneficios que obtiene una empresa se destinen al mantenimiento de la fuente (el capital) que de otra forma se extinguiría irremediablemente.

\subsubsection{Las normas contables como fuente derecho}

Mucho se ha discutido sobre el valor de las normas contables como fuente de derecho en la tributación del impuesto a la renta. No es objeto de este trabajo profundizar en dicho tema, no obstante a efectos de continuar con el análisis que haremos sobre las provisiones y castigos conviene fijar nuestra posición al respecto.

Las normas en general están dirigidas para que los destinatarios de ellas puedan entenderlas y aplicarlas y se construyen sobre la base del lenguaje común que un ciudadano promedio pueda entender $\left({ }^{11}\right)$. En particular en el derecho tributario las normas deben construirse sobre la base de un lenguaje acorde con el tributo a regular y

11 Al respecto Marcial Rubio (2009) comenta que "a diferencia de otras rama del saber, el Derecho no utiliza un lenguaje propio o simbolizado. Por el contrario, toma el lenguaje común y es elaborado mediante él. Adicionalmente, se supone que al regular las conductas de las personas en su vida social, el Derecho aspira a ser conocido, entendido y aplicado por los seres humanos al margen de su conocimiento del sistema jurídico". (p. 78). 
que además pueda ser entendido por el destinatario de la norma tributaria: el contribuyente.

En el caso del impuesto a la renta que aplica a las empresas se tiene que el legislador ha optado por elegir el lenguaje contable a efectos que pueda ser entendido y aplicado por el contribuyente, toda vez que uno de los objetivos de la contabilidad, es determinar las ganancias o pérdidas que una empresa genera a efectos que los dueños, socios, terceros o incluso el mismo estado tengan una fuente de información fiable sobre el desempeño de la empresa. Así pues, la información sobre el rendimiento financiero ayuda a los usuarios a comprender la rentabilidad que la entidad ha producido a partir de sus recursos económicos.

Ahora bien, el lenguaje contable como todo lenguaje parte de convenciones hechas por profesionales en contabilidad y que tienen un desarrollo técnico y detallado en las Normas Internacionales de Información Financiera (NIIF). Así se tiene que las NIIF son pronunciamientos profesionales que establecen la forma de preparación y presentación de los estados financieros, buscando homogenizar el lenguaje contable universal.

De acuerdo a lo establecido en el Apéndice A de la NIIF $1\left({ }^{12}\right)$, las normas e interpretaciones emitidas por el Consejo de Normas Internacionales de Contabilidad (IASB) comprenden:

- Normas Internacionales de Información Financiera,

- Las Normas Internacionales de Contabilidad.

- Interpretaciones CINIIF, e,

- Interpretaciones SIC.

Para el caso de las empresas del sistema financiero, éstas cuentan con su propio Manual de Contabilidad que tiene como objeto presentar de manera uniforme y homogénea el registro contable de las operaciones que realizan las instituciones financieras. De esta manera se obtendrán estados financieros que reflejen fielmente la situación y resultados de las operaciones y gestión de las entidades financieras, de manera que constituyan un instrumento útil para el análisis de la información y la toma de decisiones por parte de

12 Oficializado con la Resolución del Consejo Normativo de Contabilidad N 059-2015-EF/30 (norma que oficializan las versiones para el 2015). 
las instituciones responsables de la regulación y supervisión, así como para los administradores y propietarios de las instituciones, inversionistas, usuarios de servicios financieros y el público en general.

\subsubsection{Marco legal peruano}

El artículo $223^{\circ}$ de la LGS establece que "los estados financieros se preparan y presentan de conformidad con las disposiciones legales sobre la materia y con principios de contabilidad generalmente aceptados en el país."

Al respecto, el Consejo Normativo de Contabilidad, mediante Resolución $\mathrm{N}^{\circ}$ 013-98, de fecha 17.7.1998, precisa que los PCGA, comprende substancialmente, a las Normas Internacionales de Contabilidad - NIC'S y por excepción, supletoriamente, se podrán emplear los principios de contabilidad aplicados en los Estados Unidos de Norteamérica (FAS). Posteriormente el mismo Consejo, mediante Resolución N N 15-98 de fecha 14.12.1998, indica que éstos son aplicables a partir del 1.1.1998.

Por otro lado, para efectos tributarios, de acuerdo a lo establecido en el artículo $33^{\circ}$ del Reglamento de la LIR se señala que la contabilización de operaciones bajo principios de contabilidad generalmente aceptados, puede determinar, por la aplicación de las normas contenidas en la Ley, diferencias temporales y permanentes en la determinación de la renta neta. En consecuencia, salvo que la Ley o el Reglamento condicionen la deducción al registro contable, la forma de contabilización de las operaciones no originará la pérdida de una deducción. Añade la norma que, las diferencias temporales y permanentes obligarán al ajuste del resultado según los registros contables, en la declaración jurada.

Actualmente, existe una problemática sobre la utilización de las NIIF en el derecho tributario. Entre los temas discutibles se encuentra el determinar si éstas califican o no como fuente de derecho. Sin perjuicio a lo anterior, hemos notado en los últimos años que tanto los pronunciamientos del Tribunal Fiscal como de la misma Administración Tributaria han coincidido que para efecto de la determinación del impuesto a la renta, los hechos y transacciones deben contabilizarse, en principio de acuerdo con lo previsto por las normas contables, para luego realizar las conciliaciones respectivas con las normas tributarias que rigen determinadas operaciones. 
En este contexto, cabe traer a colación las conclusiones arribadas en el I Foro Internacional del IPIDET, llevado a cabo el 31.05.2012, que, entre otras, abordan el problema de la contabilidad en el derecho tributario:

- Reconocer que las normas contables y las del IR tienen finalidades distintas. Así mientras que la primera buscan delimitar el "resultado contable", las segundas regulan el "resultado tributario". Por lo tanto, acorde con estas distintas finalidades, es posible que las normas del IR se aparten de lo establecido en las normas contable.

\section{APROBADO POR UNANIMIDAD}

- Reconocer que la ley del IR debe regular exclusiva y suficientemente los elementos esenciales del Impuesto, evitando efectuar remisiones en blanco a otras normas o fuentes, tales como las normas contables. Así, las normas del IR deben regular cuidadosamente las principales instituciones contenidas en las normas contables tales como la definición de existencia, activo fijo, intangible y devengado (incluyendo la oportunidad del reconocimiento de los ingresos, costos y gastos).

APROBADO POR MAYORÍA, CON TRES VOTOS EN DESACUERDO Y UNA ABSTENCIÓN

- Reconocer que la "doctrina contable" podría constituir una fuente del derecho tributario. Sin embargo, para evitar dudas interpretativas corresponde incluirla expresamente en la relación contenida en la Norma III del Título Preliminar del Código Tributario.

\section{APROBADO POR MAYORÍA, CON DOS VOTOS EN DESACUERDO}

- Reconocer que los órganos de la Administración Tributaria y los demás intérpretes normativos no deben acudir a las normas contables y a las interpretaciones del Consejo Normativo de Contabilidad de modo automático, sino que deberán utilizar siempre la norma tributaria, considerando su finalidad, contexto y los principios que regulan la tributación.

APROBADO POR MAYORÍA, CON DOS VOTOS EN DESACUERDO 
- Incorporar expresamente en la Ley del IR, las disposiciones contenidas en su Reglamento (tales como los artículos $11^{\circ}, 33^{\circ}$ y $35^{\circ}$ ) que regulan, entre otros, la hipótesis de imposición y sus principales aspectos, tales como la descripción del hecho gravado (aspecto material) y el momento de nacimiento de la obligación tributaria (aspecto temporal).

\section{APROBADO POR MAYORÍA, CON DOS VOTOS EN DESACUERDO}

En ese sentido consideramos que actualmente las NIIF per se no tienen un rango normativo como fuente de derecho; sin embargo, en ausencia de definiciones legales, las NIIF informan sobre el contenido de los conceptos utilizados en la legislación del impuesto a la renta tal como lo haría el Diccionario de la Real Academia de la Lengua Española en el caso del derecho civil o del mismo derecho tributario en caso no tener otra fuente de definiciones. No obstante su función va más allá que un diccionario pues no solo se limita a definir los diferentes conceptos contables sino que brinda criterios sobre su forma de aplicación e interpretación.

En ese sentido las NIIF se parecen más a la doctrina como fuente de derecho, sin llegar a serlo propiamente pues estos pronunciamientos no son en estricto sobre la forma de aplicación de las normas del Impuesto a la Renta sino sobre la forma de aplicación de las normas contables que tiene una finalidad distinta.

\subsection{Provisiones para créditos y de cobranza dudosa}

\subsubsection{Evolución histórica}

La Ley $N^{\circ}$ 7904, Ley del Impuesto sobre la Renta (1934), establecía que la utilidad sujeta a impuesto era la diferencia entre la entrada bruta total y el importe de los gastos, castigos y desmedros necesarios para obtener la utilidad, siendo que para las sociedades de crédito y compañías de seguro, se contemplaba como gastos expresamente, entre otros, las cantidades que representaban la previsión que las leyes establecían para la formación de reservas técnicas o de otra naturaleza legal específica. Asimismo también se permitía como deducción una reserva equitativa para las cuentas incobrables que se hubieran comprendido en el activo, siempre que se determinen. 
Cabe precisar que en este marco normativo el Consejo Superior de Contribuciones señaló que como reserva de otra naturaleza específica en el caso de bancos procedía considerar a los castigos o provisiones ordenados por la Superintendencia de Bancos (Capuñay, 1963, p. 60).

Es con la publicación del Decreto Supremo N ${ }^{\circ}$ 287-68-HC, Texto Único del Impuesto a la Renta, (1968) donde se pone fin al imperio de la Ley $\mathrm{N}^{\circ} 7904$, quedando atrás un régimen tributario que en su etapa naciente traslucía la excelencia de un ordenamiento bien estructurado por su sistemática, su claridad y su precisión. Dentro de la normativa del referido Decreto Supremo se estableció como deducibles, entre otros, las asignaciones destinadas a constituir las reservas y otras deducciones que ordene la SBS. Asimismo en este periodo se estableció como deducibles los castigos por deudas incobrables y las previsiones equitativas por el mismo concepto, siempre que se determinen las cuentas incobrables a las que respondan (aspecto en el que ahondaremos cuando veamos la parte pertinente a los castigos).

Posteriormente, tanto con en el Decreto Legislativo $N^{\circ} 200$ (1981), como en el Decreto Legislativo $N^{\circ} 774$ (1993), normas que aprueban la Ley del Impuesto a la Renta, se contemplaba la posibilidad de deducir como gasto las asignaciones destinadas a constituir las reservas y otras deducciones que ordene la SBS, así como las reservas técnicas de las compañías de seguros y de capitalización [inciso h) del artículo $37^{\circ}$ de la LIR]. Asimismo en esta reforma se continúa aceptando como deducibles los castigos por deudas incobrables y se cambia el término "previsiones equitativas" por el de "provisiones equitativas".

Después a ello, lo que tuvimos fue una serie de reformas tributarias que nos han acompañado hasta la actualidad siendo la más relevante el Decreto Legislativo $\quad N^{\circ} 945$ (2003).

Veamos a continuación como ha sido la evolución de la deducción de los gastos correspondientes a las asignaciones destinadas a constituir las reservas y otras deducciones que ordene la SBS así como las reservas técnicas de las compañías de seguros y de capitalización, en nuestra Ley del Impuesto a la Renta: 
Tabla 1.1: Evolución en el tratamiento de las provisiones de las empresas financieras

\begin{tabular}{|c|c|}
\hline D. LEGISLATIVO & $N^{o} 26731$ \\
\hline $\begin{array}{l}\text { h) Las asignaciones destinadas a } \\
\text { constituir las reservas y otras deducciones que } \\
\text { ordene la Superintendencia de Banca y } \\
\text { Seguros así como las reservas técnicas de las } \\
\text { compañías de seguros y de capitalización. Las } \\
\text { correspondientes al ejercicio anterior que no } \\
\text { se utilicen, se considerarán como beneficio } \\
\text { sujeto al impuesto del ejercicio gravable. }\end{array}$ & $\begin{array}{l}\text { h) Tratándose de empresas del } \\
\text { sistema financiero serán deducibles las } \\
\text { provisiones específicas que no formen parte } \\
\text { del patrimonio efectivo, que ordene la } \\
\text { Superintendencia de Banca y Seguros, con } \\
\text { excepción de las que correspondan a los } \\
\text { créditos y otros activos clasificados como } \\
\text { normal. } \\
\text { Para el caso de las empresas de } \\
\text { seguros y reaseguros, serán deducibles las } \\
\text { reservas técnicas ordenadas por la } \\
\text { Superintendencia de Banca y Seguros, que no } \\
\text { forman parte del patrimonio. } \\
\text { Las provisiones y las reservas } \\
\text { técnicas a que se refiere el presente inciso, } \\
\text { correspondientes al ejercicio anterior que no } \\
\text { se utilicen, se considerarán como beneficio } \\
\text { sujeto al impuesto el ejercicio gravable. }\end{array}$ \\
\hline DECRETO LEGISLATIVO & $\mathbf{N}^{\circ} 970$ \\
\hline $\begin{array}{l}\text { h) Tratándose de empresas del } \\
\text { sistema financiero serán deducibles las } \\
\text { provisiones que, habiendo sido ordenadas por } \\
\text { la Superintendencia de Banca y Seguros, sean } \\
\text { autorizadas por el Ministerio de Economía y } \\
\text { Finanzas, previa opinión técnica de la } \\
\text { Superintendencia Nacional de Administración } \\
\text { Tributaria - SUNAT, que cumplan } \\
\text { conjuntamente los siguientes requisitos: }\end{array}$ & $\begin{array}{l}\text { h) Tratándose de empresas del } \\
\text { sistema financiero serán deducibles las } \\
\text { provisiones que, habiendo sido ordenadas por } \\
\text { la Superintendencia de Banca y Seguros, sean } \\
\text { autorizadas por el Ministerio de Economía y } \\
\text { Finanzas, previa opinión técnica de la } \\
\text { Superintendencia Nacional de Administración } \\
\text { Tributaria - SUNAT, que cumplan } \\
\text { conjuntamente los siguientes requisitos: } \\
\text { Se trate de provisiones específicas; }\end{array}$ \\
\hline
\end{tabular}




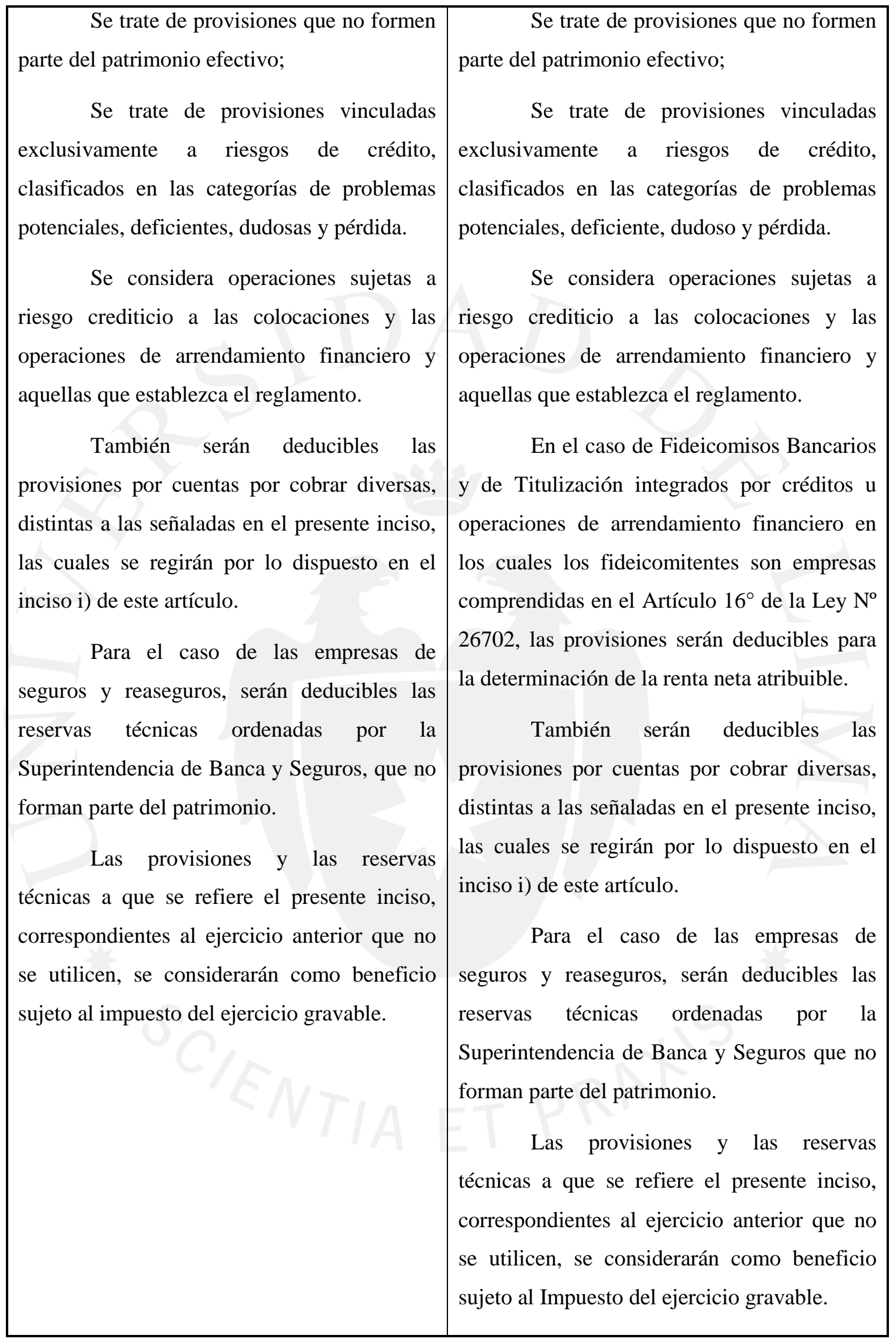


Al respecto, la doctrina señala que es frecuente que en sus prácticas comerciales, las empresas efectúen cargos que disminuyen la utilidad de un ejercicio, para reservar parte de ella a efectos de atender determinados gastos. Del mismo modo, suelen hacerse reservas para hacer frente a determinados riesgos que pueden afectar su actividad. Al respecto, García Mullín (1980) señala que el balance fiscal, en principio, no tiene por qué aceptar que la utilidad gravada del ejercicio se vea afectada por reservas para gastos que, estrictamente, ni han sido realizados, ni han sido devengados. Pero de todos modos, es frecuente encontrar en las legislaciones la autorización para que se efectúen este tipo de reservas. (p. 176)

En el caso del Perú, la Ley General del Sistema Financiero permite la constitución de provisiones con el objeto de proteger al tercero respecto de las operaciones desarrolladas por una entidad bancaria o financiera. Así pues, el numeral 4 del artículo $132^{\circ}$ de la citada Ley, establece que:

Entre las formas mediante las cuales se procura la atenuación de los riesgos para el ahorrista, se encuentra la constitución de provisiones genéricas y específicas de cartera, individuales o preventivas globales por grupos o categorías de crédito, para la eventualidad de créditos impagos, y la constitución de las otras provisiones y cargos a resultados, tratándose de las posiciones afectas a los diversos riesgos de mercado.

Fluye pues de lo anterior, que la finalidad de la norma peruana tiene como principio que la generación de rentas por la colocación de capitales lleve inherente como gasto aquéllas erogaciones destinadas a mantenerlo, reponiendo el capital que se pierde como resultado de los impagos, de tal manera que así se pueda mantener la fuente. En el caso de la deducibilidad de las provisiones ordenadas por la SBS a entidades financieras, si bien tienen una finalidad distinta a la tributaria, esto es la protección del ahorrista, consideramos que el legislador peruano ha considerado conveniente permitir su deducibilidad a efectos de reconocer en la determinación del impuesto a la renta, los riesgos propios de este sector de la actividad económica.

Ahora bien, con la publicación de la Ley $\mathrm{N}^{\circ} 26731$ (1996), norma que modifican diversos artículos de la Ley del Impuesto a la Renta, se señaló que serán deducibles las provisiones específicas que no formen parte del patrimonio efectivo, que ordene la SBS, 
con excepción de las que correspondan a los créditos y otros activos clasificados como normal.

En ese contexto, bajo una interpretación literal del artículo $133^{\circ}$ de la Ley General del Sistema Financiero, que establece que "las empresas deberán constituir, con cargo a resultados, provisiones genéricas o específicas por riesgo de crédito según la clasificación del deudor, conforme a las normas que dicte la Superintendencia”, se podía inferir que sólo las provisiones genéricas o específicas tendrían relación con las operaciones de crédito; mientras que los otros tipos de riesgos (distintos al riesgo de crédito) estarían siendo cubiertos por otro tipo de provisiones que no guardan la calificación de genéricas o específicas.

Esta interpretación como se indica en la exposición de motivos de la Ley $\mathrm{N}^{\circ} 26731$ (1996), no obstante su simpleza, fue modificada por la misma SBS, a través de la Circular B-2038-99 (1999), en donde la referida entidad estableció que las provisiones genéricas son aquellas que se constituyen sobre la cartera calificada como normal y que, en consecuencia, cualquier tipo de provisión diferente a la genérica establecida por este órgano de control tiene la calidad de específica, sin que sea necesario indicarlo expresamente $\left({ }^{13}\right)$.

Es así que durante la vigencia de esta Circular, los efectos de tal interpretación eran los siguientes:

(i) Se amplió el concepto de provisión específica a cualquier otro riesgo que no necesariamente esté vinculado con operaciones de crédito, contrariamente a la intención que fluye de la Ley General del Sistema Financiero $\left({ }^{14}\right)$.

13 Debemos mencionar, como antecedente, que hasta diciembre del año 2003, la deducción de las provisiones efectuadas por empresas del sistema financiero estaban limitadas a las que (i) fueran ordenadas por la SBS con la calidad de (ii) provisiones específicas (calificadas por la SBS) (iii) que no formasen el patrimonio efectivo de estas empresas y (iv) que correspondan a créditos y otros activos clasificados como "normal" por las normas prudenciales de la SBS. En otras palabras, la deducibilidad de las provisiones en este ámbito resultaba de un alcance amplio y dependía un poco de la calificación de "específicas" que dicha entidad supervisora pudiera atribuir a las provisiones en general.

14 Bajo esta interpretación la SBS ha opinado, inclusive en documentos internos (tales como el Oficio $\mathrm{N}^{\circ}$ 510-99-SBS) que nos encontramos ante provisiones específicas, distintas a las provisiones vinculadas a colocaciones de crédito, en los siguientes casos: Provisión por bienes adjudicados y recuperados, por fluctuación de valores, por cuentas por cobrar distintas a las colocaciones, por los derechos que generen a favor de los fideicomitentes en contratos de fideicomiso y por transferencia y adquisición de cartera crediticia. 
(ii) Se estableció expresamente que no será necesario una calificación previa por parte de la SBS para otorgar la calidad de específica a una determinada provisión, ya que de acuerdo a su interpretación, cualquier provisión que no sea genérica será por exclusión específica, aun cuando del texto de la misma Ley General del Sistema Financiero fluye que pueden existir otras provisiones distintas a las genéricas y específicas.

Queda claro que, la problemática planteada en la exposición de motivos, referente al contexto antes mencionado, es que hasta antes del 01.01.2004 la SBS había emitido distintos actos administrativos que, al regular los tipos de provisiones específicas, indirectamente habían originado efectos tributarios no deseados, incluso como se vio anteriormente al ampliar el concepto de provisión específica, ocasionó una interpretación más extensa que la que hoy fluye de la norma tributaria.

Siendo ello así, la SUNAT en aplicación de la norma vigente en esos ejercicios, debía tomar en cuenta las normas específicas de la SBS sobre la evaluación y clasificación de la cartera de créditos, según la cual la SBS debía evaluar regularmente el cumplimiento por parte de las instituciones supervisadas, de las disposiciones bajo las cuales se realizaba el proceso de evaluación y clasificación de la cartera de créditos.

Bajo esta coyuntura, se publicó el Decreto Legislativo $N^{\circ} 945$ (2003), norma que modificó el inciso h) del artículo $37^{\circ}$ de la LIR y exigió a partir del 1.1.2004 la opinión técnica de la SUNAT y la autorización del Ministerio de Economía y Finanzas de las disposiciones emitidas por la SBS para poder tener efectos tributarios.

Con esta norma los requisitos para la deducibilidad de las deducciones se hicieron más rígidos, pues éstas se limitaron a las provisiones por riesgo de crédito tales como las colocaciones y operaciones de arrendamiento financiero, eliminándose las provisiones por fluctuación de valores, las provisiones por cambio en la capacidad crediticia del emisor, las provisiones en relación a bienes adjudicados o recuperados, aclarándose que tampoco se consideran provisiones vinculadas a riesgos de crédito las cuentas por cobrar.

Otro punto, que se aclara con la vigencia del Decreto Legislativo № 945 (2003), y se explica también en su exposición de motivos, es que existen dos regímenes diferentes para la deducibilidad de las provisiones por parte del sistema financiero, que son: 
- Las regulaciones propias para las provisiones por deudas incobrables, establecidas en el inciso i) del artículo $37^{\circ}$ de la LIR.

- Las provisiones ordenadas por la SBS vinculadas a operaciones de crédito y de arrendamiento financiero, que cumplan los requisitos establecidos en el inciso h) del artículo $37^{\circ}$ de la LIR.

En efecto, con la normativa anterior resultaba que una entidad bancaria o financiera podría estar enfrentando una situación tributaria en desventaja respecto de cualquier otro contribuyente que sí podría deducir cualquier tipo de crédito que resulte irrecuperable, por ende, se aprobó la deducción de las provisiones para aquellas que no se encuentren vinculadas al negocio principal de la entidad financiera o bancaria, siendo así a partir del 01.01.2004 las empresas del sistema financiero pueden deducir por ejemplo provisiones que arrojen las siguientes operaciones (i) venta de un activo fijo del banco, (ii) operaciones de fideicomiso por las que tiene un ingreso pendiente de cobro, (iii) arrendamientos insolutos provenientes de bienes adjudicados, etc; siempre que se cumplan con los requisitos exigidos en la LIR.

\subsubsection{Naturaleza contable de las provisiones para créditos de cobranza dudosa}

\subsubsection{Regulación pertinente de Superintendencia de Banca y Seguros}

El numeral 4 del artículo $132^{\circ}$ de la Ley General del Sistema Financiero, señala que en aplicación del artículo $87^{\circ}$ de la Constitución Política del Perú, son formas mediante las cuales se procura, adicionalmente la atenuación de los riesgos para el ahorrista, entre otros, la constitución de provisiones genéricas $\left({ }^{15}\right)$ y específicas $\left({ }^{16}\right)$ de cartera, individuales o preventivas globales por grupos o categorías de crédito, para la

\footnotetext{
15 Las provisiones genéricas son aquellas que se constituyen, de manera preventiva, sobre los créditos directos y la exposición equivalente a riesgo crediticio de los créditos indirectos de deudores clasificados en categoría Normal.

${ }^{16}$ Las provisiones específicas son aquellas que se constituyen sobre los créditos directos y la exposición equivalente a riesgo crediticio de los créditos indirectos de deudores a los que se ha clasificado en una categoría de mayor riesgo que la categoría Normal.
} 
eventualidad de créditos impagos, y la constitución de las otras provisiones y cargos a resultados, tratándose de las posiciones afectas a los diversos riesgos de mercado.

Por su parte, el artículo $133^{\circ}$ de la citada Ley establece que "las empresas deberán constituir, con cargo a resultados, provisiones genéricas o específicas por riesgo de crédito según la clasificación del deudor, conforme a las normas que dicte la SBS.”

Así pues, el artículo $222^{\circ}$ de la referida Ley establece que con relación a las operaciones que integran la cartera crediticia, deberá tenerse presente que para su evaluación se tomará en cuenta los flujos de caja del deudor, sus ingresos y capacidad de servicio de la deuda, situación financiera, patrimonio neto, proyectos futuros y otros factores relevantes para determinar la capacidad del servicio y pago de deuda del deudor. El criterio básico es la capacidad de pago del deudor.

Por otro lado, los numerales 6, 7, 9 y 13 del artículo $349^{\circ}$ de la Ley General del Sistema Financiero señalan como atribuciones de la Superintendencia las siguientes:

El interpretar, en la vía administrativa, sujetándose a las disposiciones del derecho común y a los principios generales del derecho, los alcances de las normas legales que rigen a las empresas del sistema financiero y del sistema de seguros, así como a las que realizan servicios complementarios, constituyendo sus decisiones precedentes administrativos de obligatoria observancia (numeral 6); aprobar o modificar los reglamentos que corresponda emitir a la Superintendencia (numeral 7); dictar las normas necesarias para el ejercicio de las operaciones financieras y de seguros, y servicios complementarios a la actividad de las empresas y para la supervisión de las mismas, así como para la aplicación de la presente Ley (numeral 9); y dictar las normas generales para precisar la elaboración, presentación y publicidad de los estados financieros, y cualquier otra información complementaria, cuidando que se refleje la real situación económico-financiera de las empresas, así como las normas sobre consolidación de estados financieros de acuerdo con los principios de contabilidad generalmente aceptados (numeral 13).

A su vez, el numeral 1 del artículo $354^{\circ}$ de la referida Ley General del Sistema Financiero agrega que: 
Para los efectos a que se refiere el numeral 13 del artículo $349^{\circ}$, la SBS está autorizada para exigir a los supervisados que constituyan provisiones y reservas para los activos y contingentes que comporten riesgos crediticio o de mercado, de acuerdo a las normas generales que sobre el particular haya dictado.

Siendo ello así y en el marco de las normas glosadas de la Ley General del Sistema Financiero, mediante Resolución S.B.S. N 11356-2008, se aprobó el Reglamento para la Evaluación y Clasificación del Deudor y la exigencia de provisiones, norma que estableció en su Capítulo I los conceptos y principios para la evaluación y clasificación del deudor y la exigencia de provisiones, que califican como normas de estricto cumplimiento para las instituciones supervisadas por la SBS al momento de realizar las provisiones que serán materia de deducción.

Como se colige del referido Reglamento, se desprende que las provisiones que pueden ser deducidas como gasto tributario, por parte de las empresas del sistema financiero, son las provisiones específicas (con riesgo superior al normal) que no formen parte del patrimonio efectivo, vinculadas exclusivamente a riesgo de crédito, clasificados en las categorías de problemas potenciales, deficiente, dudoso y pérdida. En tal sentido, son deducibles, las constituidas por créditos directos y operaciones de arrendamiento financiero sean vigentes, refinanciados, reestructurados, vencidos o en cobranza judicial.

En consecuencia, no son deducibles las provisiones por créditos indirectos ni las que se constituyan en relación a deudores por venta de bienes realizables, devueltos, recibidos en pago y adjudicados, así como las provisiones originadas por riesgos distintos al crediticio como la provisión por la diferencia entre el valor presente de las deudas refinanciadas y/o reestructuradas y el valor en libros de las mismas.

A manera de ejemplo, si una empresa del sistema financiero otorga un crédito a un cliente que viene pagando y es clasificado como "Normal" la provisión que genere al respecto será genérica y por tanto no deducible como gasto tributario. Sin embargo, si esa misma empresa del sistema financiero otorga otro crédito a un cliente que tiene dificultades para pagar y es clasificado como "Deficiente" la provisión que genera será específica y podrá ser deducido como gasto tributario.

En corolario de las normas expuestas, se puede afirmar que si bien existe una obligación legal por parte de las empresas del sistema financiero para la clasificación 
del deudor y se exige la contabilización de provisiones, este efecto es únicamente sectorial, posterior a ello se deberá evaluar el cumplimiento de los requisitos tributarios para hacer deducible dichas provisiones en la determinación de la renta neta imponible.

\subsubsection{Dinámica contable sobre las provisiones de crédito y de cobranza dudosa}

La Norma Internacional de Contabilidad (NIC) $N^{o} 32$ - Instrumentos Financieros $\left({ }^{17}\right)$ define a los activos financieros, entre otros, como un derecho contractual a recibir efectivo u otro activo financiero de otra entidad. Agrega que son ejemplos comunes de activos financieros: (a) cuentas por cobrar y por pagar de origen comercial; (b) pagarés por cobrar y por pagar; (c) préstamos por cobrar y por pagar; y (d) obligaciones o bonos por cobrar y por pagar.

Por su parte, el término "provisión" se utiliza en el contexto de partidas tales como la depreciación y la pérdida de valor por deterioro de activos o de los deudores de dudoso cobro. En el caso particular de la provisión de cobranza dudosa, es una provisión contable cuyo propósito es ajustar el valor en libros del activo financiero cuando éste sea mayor a su importe recuperable estimado, ello con la finalidad de mostrar en el balance general de las empresas el importe del activo que realmente se espera que genere beneficios económicos futuros.

En esa línea, el numeral 3 del Capítulo III de la Resolución SBS N ${ }^{\circ}$ 11356$2008\left({ }^{18}\right)$, establece que:

Las empresas deben constituir las provisiones genéricas y específicas sobre los créditos directos y la exposición equivalente a riesgo crediticio de los créditos indirectos. Dichas provisiones constituidas se registrarán conforme a las disposiciones contenidas en el Manual de Contabilidad para las empresas del sistema financiero $\left({ }^{19}\right)$.

Con relación a las provisiones para créditos contempladas en el inciso h) de la LIR, dicho Manual señala que estas provisiones se constituirán con cargo a gastos del

17 Versión 2015 oficializado con la Resolución del Consejo Normativo de Contabilidad N ${ }^{059-2015-}$ $\mathrm{EF} / 30$.

18 Norma que aprobó el nuevo Reglamento para la Evaluación y Clasificación del Deudor y la exigencia de provisiones.

19 http://www.sbs.gob.pe/principal/categoria/bancos-financieras-y-otros/117/c-117. 
ejercicio, afectando el Estado de Ganancias y Pérdidas. Siendo así, en la dinámica contable al efectuar una provisión intervienen: (i) un cargo a la cuenta de gastos y (ii) un abono a la cuenta de activo por la estimación que origina el deterioro. A tal efecto, el Capítulo V del Manual de Contabilidad para las Empresas del Sistema Financiero, contempla la dinámica contable para su aplicación.

A modo ejemplo, a continuación presentamos la dinámica contable de la cuenta 1409 - Provisiones para créditos, de acuerdo a lo establecido en el Capítulo V del Manual de Contabilidad para las Empresas del Sistema Financiero:

\section{Cuenta 1409: Provisiones para Créditos.-}

En esta cuenta se registran las provisiones genéricas y específicas por créditos directos conforme con las disposiciones emitidas en el Reglamento para la Evaluación y Clasificación del Deudor y la Exigencia de Provisiones. Asimismo, cuando corresponda, se registrarán las provisiones por riesgo cambiario crediticio y las provisiones genéricas adicionales referidas a la administración inadecuada del riesgo de sobreendeudamiento conforme a las disposiciones emitidas por la SBS. Añade que, las provisiones, excepto, las constituidas por riesgo país, se contabilizan en esta cuenta.

Las provisiones por riesgo país se contabilizan en la cuenta analítica 2702.05.04. Para efectos de presentación los créditos se presentan deducidos de todas las provisiones señaladas anteriormente. Las provisiones deberán constituirse en la misma moneda en que fueron pactados los créditos que la originan.

A continuación presentamos la dinámica contable:

\section{Débitos (se carga):}

- Por la reversión de provisiones.

- Por la aplicación de los saldos de las provisiones acumuladas correspondientes a los saldos de los créditos castigados o retirados del activo.

- Por la actualización de los saldos en moneda extranjera.

\section{Créditos (se abona):}

- Por la constitución de provisiones conforme con lo dispuesto en el Reglamento para la Evaluación y Clasificación del Deudor y la Exigencia de Provisiones. 
- Por la constitución de provisiones por riesgo cambiario crediticio.

- Por la constitución de provisiones correspondientes a la administración inadecuada del riesgo de sobreendeudamiento.

- Por la actualización de los saldos en moneda extranjera.

Con esta dinámica queda claro que cuando se registran estas provisiones dicho importe incide, por un lado en los resultados de la compañía y, por otro en la deducción del costo del activo financiero. En consecuencia, en el caso de activos íntegramente provisionados, para efectos contables, el costo del activo financiero equivaldría a cero en el ejercicio en que se realizó dicha provisión.

\subsubsection{Naturaleza tributaria de las provisiones para créditos y de cobranza dudosa}

\subsubsection{Regulación tributaria de las provisiones para créditos y colocaciones}

\section{a) Ámbito de Aplicación}

En virtud a lo establecido en el artículo $37^{\circ}$ de la LIR se dispone que "a fin de establecer la renta neta de tercera categoría se deducirá de la renta bruta los gastos necesarios para producirla y mantener su fuente, así como los vinculados con la generación de ganancias de capital".

A tal efecto, para el caso de las empresas del sistema financiero podrán deducir como gasto para efectos de la determinación de la renta neta, las provisiones que, habiendo sido ordenadas por la SBS, sean autorizadas por el Ministerio de Economía y Finanzas mediante Resolución Ministerial $\left({ }^{20}\right)$, previa opinión técnica de la Superintendencia Nacional de Administración Tributaria (SUNAT). Las provisiones autorizadas, tendrán efecto tributario a partir del ejercicio gravable en que se emita la Resolución Ministerial.

20 Para tal efecto, la SBS deberá poner en conocimiento del Ministerio de Economía y Finanzas las normas a través de las cuales ordene la constitución de provisiones, dentro de los 15 días hábiles siguientes a su emisión. El Ministerio de Economía y Finanzas dentro de los 3 días hábiles siguientes a la fecha de recepción de la comunicación, requerirá a la SUNAT, para que dentro de los 10 días hábiles siguientes a la fecha de recepción del requerimiento, emita opinión técnica al respecto. Vencido dicho plazo el Ministerio de Economía y Finanzas, mediante Resolución Ministerial, autorizará la deducción de las provisiones ordenadas por la SBS que correspondan. 


\section{b) Requisito de deducibilidad}

A efectos de gozar con dicha deducción se deben cumplir conjuntamente los siguientes requisitos:

b.1) Se trate de provisiones específicas.

Cabe señalar que la primera fuente normativa que hace alusión a las provisiones de tipo específico es la Ley General del Sistema Financiero, que en su artículo $133^{\circ}$ establece que las empresas deberán constituir, con cargo a resultados, provisiones genéricas o específicas por riesgo de crédito según la clasificación del deudor, conforme a las normas que dicte la $\operatorname{SBS}\left({ }^{21}\right)$.

Por su parte, el Reglamento define a las Provisiones específicas como aquéllas que se constituyen con relación a créditos directos y operaciones de arrendamiento financiero, respecto de los cuales se ha identificado un riesgo superior al normal.

b.2) Se trate de provisiones que no formen parte del patrimonio efectivo;

Dicho patrimonio efectivo podrá ser destinado a cubrir riesgo de crédito, riesgo de mercado y riesgo operacional. Será determinado sumando el patrimonio básico y el patrimonio suplementario.

b.3) Se trate de provisiones vinculadas exclusivamente a riesgos de crédito, clasificados en las categorías de problemas potenciales, deficiente, dudoso y pérdida.

Es importante destacar que las provisiones que resultan deducibles, son todas aquellas vinculadas al negocio principal de la entidad financiera o bancaria, esto es, las operaciones de crédito sujetas a riesgo crediticio y a las colocaciones y las operaciones de arrendamiento financiero.

Se entenderá por riesgo crediticio, a aquel riesgo que asume una empresa del sistema financiero, de que el deudor o la contraparte de un contrato financiero no cumplan con las condiciones del contrato.

21 Nótese que bajo una interpretación literal de la Ley General del Sistema Financiero, sólo las provisiones genéricas o específicas tendrían relación con las operaciones de crédito; mientras que los otros tipos de riesgos (distintos al riesgo de crédito) estarían siendo cubiertos por otro tipo de provisiones que no guardan la calificación de genéricas o específicas. Esta interpretación, fue modificada por la misma SBS. Mediante Circular No B-2038-99 la citada entidad ha establecido que las provisiones genéricas son aquellas que se constituyen sobre la cartera calificada como normal y que, en consecuencia, cualquier tipo de provisión diferente a la genérica establecida por este órgano de control tiene la calidad de específica, sin que sea necesario indicarlo expresamente. 
Por otro lado de acuerdo al numeral 1 del literal e) del artículo 21 del Reglamento de la LIR, las Colocaciones, se definen como:

Créditos directos, entendiéndose como tales las acreencias por el dinero otorgado por las empresas del sistema financiero bajo las distintas modalidades de crédito, provenientes de sus recursos propios, de los recibidos del público en depósitos y de otras fuentes de financiamiento interno o externo.

Se consideran créditos directos a los créditos vigentes, créditos refinanciados, créditos reestructurados, créditos vencidos, créditos en cobranza judicial y aquellos comprendidos como tales en las normas contables aplicables a las empresas del sistema financiero.

Por lo tanto, se excluyen de la deducción cualquier otra provisión que pretenda proteger de un riesgo distinto al de crédito, es decir, no constituyen provisiones deducibles, las siguientes:

- Las provisiones originadas por fluctuación de valores o provisiones por cambios en la capacidad crediticia del emisor.

- Las provisiones que se constituyan en relación a los bienes adjudicados o recuperados, tales como las provisiones por desvalorización y las provisiones por bienes adjudicados o recuperados.

- Las provisiones por cuentas por cobrar distinta a las colocaciones.

- Provisiones por los derechos que generen a favor de los fideicomitentes en contratos de fideicomiso.

- Provisiones por transferencia y adquisición de cartera crediticia.

Finalmente, debe entenderse por arrendamientos financieros a los que se regulan por su respectiva legislación.

Ahora bien, la legislación tributaria señala en el inciso h) del artículo 37 de la LIR que en el caso de las Empresas de Seguros y Reaseguros, también serán deducibles las reservas técnicas ordenadas por la SBS que no forman parte del patrimonio. A tal efecto, se considera que las reservas técnicas de siniestros que las empresas de seguros y reaseguros constituyen por orden de la SBS son utilizadas durante todo el tiempo en que estén destinadas a asegurar el pago de la indemnización del siniestro ocurrido. 
Añade la norma que, las provisiones y las reservas técnicas correspondientes al ejercicio anterior que no se utilicen, se considerarán como beneficio sujeto al Impuesto del ejercicio gravable.

De lo anterior se puede inferir que, las provisiones serán deducibles para efectos de la determinación de la renta neta, en la medida en que las normas del impuesto a la renta lo permitan, lo que supone que en principio no todas las provisiones pueden gozar de esta facilidad.

Siendo ello así, la LIR ha establecido una regulación expresa para que las empresas del sistema financiero puedan deducir, para efectos tributarios, el gasto originado por las provisiones de crédito, siempre y cuando cumplan con los requisitos especificados en los incisos h) del artículo $37^{\circ}$ de la LIR ya explicado anteriormente.

En consecuencia, se puede concluir que la provisión de deudas incobrables por créditos constituye una de las provisiones admitidas por la LIR, estando sujeta su deducción tributaria al cumplimiento de los requisitos establecidos en la norma.

\subsubsection{Regulación tributaria de las provisiones de cobranza dudosa}

Por otro lado, el inciso i) del artículo $37^{\circ}$ de la LIR dispone que son deducibles para la determinación del impuesto a la renta, las provisiones equitativas por deudas de cobranza dudosa, siempre que se determinen las cuentas a las que corresponden. En relación a las empresas del sistema financiero el referido inciso i) señala que:

Podrán efectuar la deducción de provisiones siempre que se encuentren vinculadas a cubrir riesgos por cuentas por cobrar diversas como reclamos a terceros, adelantos al personal, indemnizaciones reclamadas por siniestros, contratos de arrendamiento financiero resueltos pendientes de recuperación de los bienes, entre otros.

No se encuentran comprendidas las provisiones por créditos indirectos ni las provisiones para cubrir riesgos de mercado, entendiéndose como tal al riesgo de tener pérdidas en posiciones dentro y fuera de la hoja del balance, derivadas de movimientos en los precios de mercado, incluidos los riesgos pertenecientes a los instrumentos relacionados con tasas de interés, riesgo cambiario, cotización de las acciones, "commodities", y otros.

A efectos de realizar la provisión de deudas incobrables se deberá tener en cuenta las siguientes reglas: 
1. El carácter de deuda incobrable o no deberá verificarse en el momento en que se efectúa la provisión contable.

2. Para efectuar la provisión por deudas incobrables se requiere:

a) Que la deuda se encuentre vencida y se demuestre la existencia de dificultades financieras del deudor que hagan previsible el riesgo de incobrabilidad, mediante análisis periódicos de los créditos concedidos o por otros medios, o se demuestre la morosidad del deudor mediante la documentación que evidencie las gestiones de cobro luego del vencimiento de la deuda, o el protesto de documentos, o el inicio de procedimientos judiciales de cobranza, o que hayan transcurrido más de doce (12) meses desde la fecha de vencimiento de la obligación sin que ésta haya sido satisfecha; y,

b) Que la provisión al cierre de cada ejercicio figure en el Libro de Inventarios y Balances en forma discriminada.

Con relación a la provisión, en cuanto se refiere al monto, se considerará equitativa si guarda relación con la parte o el total si fuere el caso.

\section{Provisiones de cobranza dudosa que no califican como deuda incobrable:}

De otro lado, no se reconoce el carácter de deuda incobrable a:

\section{- Las deudas contraídas entre sí por partes vinculadas,}

Se entenderá que existe una nueva deuda contraída entre partes vinculadas cuando con posterioridad a la celebración del acto jurídico que da origen a la obligación a cargo del deudor, ocurre lo siguiente:

(i) Cambio de titularidad en el deudor o el acreedor, sea por cesión de la posición contractual, por reorganización de sociedades o empresas o por la celebración de cualquier otro acto jurídico, de lo cual resultara que las partes se encuentran vinculadas.

(ii) Alguno de los supuestos que ocasione la vinculación de las partes. 
- Las deudas afianzadas por empresas del sistema financiero y bancario, garantizadas mediante derechos reales de garantía, depósitos dinerarios o compra de venta con reserva de propiedad;

Se entiende por deudas garantizadas mediante derechos reales de garantía a toda operación garantizada o respaldada por bienes muebles e inmuebles del deudor o de terceros sobre los que recae un derecho real.

Podrán calificar como incobrables:

- La parte de la deuda que no sea cubierta por la fianza o garantía.

- La parte de la deuda que no ha sido cancelada al ejecutarse la fianza o las garantías.

- Las deudas que hayan sido objeto de renovación o prórroga expresa.

Se considera deudas objeto de renovación:

- Sobre las que se produce una reprogramación, refinanciación o reestructuración de la deuda o se otorgue cualquier otra facilidad de pago.

- Aquellas deudas vencidas de un deudor a quien el mismo acreedor concede nuevos créditos.

Cumplido el plazo de vencimiento de las deudas renovadas o prorrogadas, la provisión de éstas se podrá deducir en tanto califiquen como incobrables.

De lo expuesto, se puede notar que tanto las provisiones de crédito como las de cobranza dudosa tienen sus propias reglas de juego, por ejemplo, a diferencia de las provisiones de crédito, las de cobranza dudosa si tendrá en cuenta que la deuda impaga a provisionar no sea de cargo de una empresa vinculada puesto que, de ser así no podrá ser deducida como gasto, ya que la norma expresamente prohíbe su deducción.

En tal sentido, las provisiones por cuentas por cobrar distintas a los créditos también constituyen una de las provisiones admitidas por la LIR, estando sujeta su deducción tributaria al cumplimiento de los requisitos establecidos en la norma.

En consecuencia, se puede concluir que el gasto por la constitución de provisiones de cobranza dudosa, establecidas al amparo del inciso i) del artículo $37^{\circ}$ de 
la LIR, que fuera aceptado tributariamente para efectos de establecer la renta neta de tercera categoría generaría que el valor del activo financiero se vea disminuido en la misma proporción.

A tenor de lo expuesto, en esta primera etapa, en el caso de activos íntegramente provisionados que cumplan con los requisitos establecidos en el inciso h) e i) del artículo $37^{\circ}$ de la LIR, tanto para efectos contables como tributarios, el costo del activo financiero equivaldría a cero en el ejercicio que se realiza la provisión $\left({ }^{22}\right)$.

22 Cabe precisar que, evidentemente el criterio sería diferente en el caso que la citada provisión no resultará deducible, el efecto tributario en el costo computable de dichos bienes se mantendrá al mismo valor sin considerar la disminución producto de su provisión. 


\section{CAPÍTULO II: CASTIGO DE CRÉDITOS INCOBRABLES}

\subsection{Evolución histórica}

El artículo $17^{\circ}$ de la Ley $\mathrm{N}^{\circ} 7904$ (1934), establecía que el impuesto sobre las utilidades que se obtengan de la industria y el comercio, grava, entre otros sectores, la utilidad líquida obtenida por los establecimientos bancarios o de crédito.

Por su parte, el artículo $18^{\circ}$ de la referida Ley, señalaba que comprende como utilidad sujeta al impuesto, la diferencia entre la entrada bruta total y el importe de los gastos, castigos y desmedros necesarios para obtener dicha utilidad. Agregaba el artículo $19^{\circ}$, que se consideran como gastos, castigos y desmedros, -relacionado al tema que nos ocupa-, entre otros a: (i) las cantidades que representan la previsión que las leyes establezcan para la formación de reservas técnicas, matemáticas o de otra naturaleza legal específica, para las sociedades de crédito y compañías de seguro; y, (m) los intereses que paguen las instituciones de crédito a sus imponentes, así como cualquiera otras deducciones que ordene la Superintendencia de Bancos.

Ahora bien, el inciso d) del artículo $20^{\circ}$ de la citada Ley, establecía que al fijarse la renta líquida sujeta al impuesto sobre las utilidades industriales y comerciales se podía efectuar también la deducción de una reserva equitativa para las cuentas incobrables que se hubiera comprendido en el activo, siempre que se determinen.

Por otro lado, el artículo $11^{\circ}$ del Reglamento del Impuesto sobre las Utilidades Comerciales e Industriales, señalaba que se aceptará la formación de una reserva equitativa paras las cuentas incobrables que figuren en el activo, siempre que se determinen en un Anexo que se acompañará al Balance; quedando entendido que mientras exista esta reserva, el castigo de las malas deudas correspondientes deberá cargarse a ella. Agrega, que para aceptar el castigo de una cuenta incobrable, se necesita que haya figurado en los libros desde que se produjo la deuda, debiendo rechazarse los que se refieren a deudores incorporados solamente en la fecha del balance.

Finaliza, la norma reglamentaria, indicando que no se considerarán deudas incobrables las de las personas con las cuales no se haya ejercitado todas las acciones 
legales de cobranza, salvo que se demuestre que sea inútil ejercitarlas, o no se haya querido hacer efectivas las garantías contenidas.

De las normas glosadas, se puede inferir que la intención del legislador, en un primer momento, era que se acepte como gasto deducible una provisión o reserva equitativa a las cuentas por cobrar, en la medida que éstas figurasen en el activo del balance y que se encuentren en situación de incobrables, esto es, el único requisito era llevar un Anexo que discrimine dichas cuentas con la finalidad de llevar el control tributario de los mismos. En tal sentido, si no figuraba la reserva por malas deudas en la contabilidad (esto es el Balance del año correspondiente) no procedía aceptar la reserva creada como gasto deducible de la utilidad.

Nótese que todo castigo que se realizará de las referidas cuentas incobrables debía realizarse con cargo a dicha provisión de tal manera que no se pierda el control tributario. Así pues, en el caso que el deudor efectúe su pago, se debería efectuar la reversión de la citada provisión y el pago del impuesto a la renta correspondiente a dicha renta.

Siendo así cobra sentido, que al momento de efectuar el castigo, el legislador exigía como requisito previo, el agotamiento de la acción judicial de cobranza de los créditos; con lo cual, si se realizaba un pago futuro, no se eluda la tributación respecto del mismo, toda vez, que como hemos visto con dicha operación contable se eliminaba la cuenta por cobrar que le dió origen, y se perdía el control tributario de las deudas desagregadas en el Balance.

No obstante a ello, siempre se ha tenido la posibilidad de castigar deudas menores. En un primer momento de S/. 2,000.00, luego S/. 5,000.00, posteriormente en función del sueldo mínimo vital mensual de la actividad industrial vigente en la provincia de Lima y finalmente, como es hoy, de la UIT; esto es, la intención del legislador es que no se incurran en mayores costos judiciales cuando los montos de cobranza dudosa son menores, ya que podría resultar más oneroso el cumplimiento del requisito legal que la recuperación de la propia deuda.

En esa misma línea, existe jurisprudencia del Tribunal Fiscal, que señalaban que la provisión implicaba la formación de una reserva por lo que es diferente al castigo $\left({ }^{23}\right)$. Por el contrario al no haberse constituido la provisión, el castigo se podía practicar de

23 Tales como la Resoluciones del Tribunal Fiscal N. ${ }^{\circ}$ s 016-1964, 10950-1975, 015777-1980. 
forma directa afectando los resultados del ejercicio $\left({ }^{24}\right)$; incluso el Tribunal levantó el reparo cuando se contaba con la documentación que sustentaba la incobrabilidad de la deuda sin previamente haberse realizado la provisión, por considerar que cumplía con la finalidad de su incobrabilidad.

En tal sentido, si bien la intención del legislador originalmente era controlar la deducción de la utilidad que se afectaba con la generación de reservas vía una provisión, la práctica contable, como hemos visto de los denominados "castigos directos", motivaron que el Tribunal Fiscal, haga prevalecer la realidad que estaba detrás de la contabilidad, esto es, que si bien se pudo haber realizado un "castigo", sin previa provisión, realmente se trataban de deudas cuya incobrabilidad se había demostrado fehacientemente, con lo cual, se puede afirmar que posteriormente lo que se buscaba controlar era tanto el castigo como la formación de reservas, en la medida en que éstas disminuyeran el importe de la utilidad.

Así lo establece la Resolución del Tribunal Fiscal N 03677-1968, que señala que de la documentación presentada por la recurrente (copias certificadas de los actuados judiciales y oficio de la Cámara de Comercio y Agricultura de Pisco), se desprende que el deudor por sus antecedentes y su situación económica, no podía satisfacer la deuda contraída con la reclamante, y si bien es verdad que ésta se adelantó al efectuar el castigo total de la deuda, en vez de constituir una reserva por el monto de la misma, -lo que hubiera sido aceptado por la Administración Tributaria-, también es cierto, que de las pruebas presentadas llevan a la conclusión que la deuda es efectivamente incobrable, por lo que, estando al mérito de esas pruebas el Tribunal en este caso, procede a dejar sin efecto el reparo.

Con lo cual, podemos concluir que el castigo deducible para efectos tributarios, cobra sentido en los siguientes escenarios:

1. Que se realice de manera directa afectando los resultados del ejercicio, y por ende se disminuya el impuesto a pagar.

2. Que disminuye la base de algún impuesto que grave los activos.

3. Que se disminuya vía provisión y luego se transfiera vía venta o proceso de reorganización empresarial y finalmente se pierda el control tributario, pudiendo dejar de tributar la renta en una posterior recuperación.

24 Tales como la Resoluciones del Tribunal Fiscal N. ${ }^{\circ}$ s 5580-1970, 3677-1968. 
Sobre el primer punto, que el castigo se realice de manera directa afectando

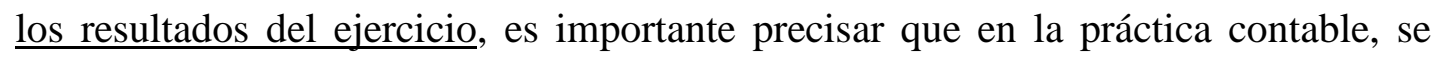
pueden realizar eliminaciones a las cuentas del activo sin generar una provisión previa, esto es los denominados “castigos directos". Así pues, en esta operación se genera, normalmente, un cargo a los resultados del ejercicio con abono a la cuenta de cobranza dudosa, provocando una disminución de la utilidad en dicho ejercicio, con esta operación se logra el mismo objetivo que la constitución de reserva a través de la provisión. A modo de ejemplo podemos citar la Resolución del Tribunal Fiscal $\mathrm{N}^{\circ}$ 0117-1964, que sostiene que la recurrente ha efectuado las gestiones a su alcance con el fin de hacer efectiva las deudas pero que todas ellas han resultados infructuosas. Por lo tanto, se mantiene el reparo por tratarse de un castigo directo de los saldos deudores $\mathrm{y}$, además no fue suficiente las pruebas presentadas para acreditar la fehaciencia y su incobrabilidad (el subrayado es nuestro).

Sobre el segundo punto, que el castigo disminuye la base de algún impuesto que grave los activos, cabe precisar que la eliminación de la cuenta por cobrar rebaja el importe patrimonial así como el activo de la compañía, en ese sentido, si el castigo no cumple los requisitos para tener efecto tributario no debería disminuir la base imponible de aquellos tributos cuya base imponible se computa sobre el total de activos netos, como era el caso del Impuesto al Patrimonio Empresarial. A modo de ejemplo podemos citar la RTF 15534-1979, en la que se confirma la deducibilidad del castigo directo para efectos del Impuesto al Patrimonio Empresarial.

Finalmente, el tercer punto, que establece que el castigo actúa como provisión y luego se transfiera vía venta o proceso de reorganización empresarial, la jurisprudencia hace referencia a que al momento en que se transfiera una compañía o se realice algún proceso de reorganización empresarial, puede ocasionar que dicha renta termine por no tributar; como fue el caso analizado en la Resolución de Tribunal Fiscal 564-1964, donde la Administración Tributaria señaló que, no procede ninguna deducción, toda vez que se trataba de un nuevo negocio que, al asumir el activo de una anterior compañía, lo hizo al valor de los saldos de sus diferentes cuentas, esto es, considerando las amortizaciones que hasta la fecha se había efectuado. Que si bien esto no fue así la empresa no puedo acreditar qué 
cuentas del activo y del pasivo le fueron aportados y por tanto se desconoce cuáles fueron los excesos del castigo que le serían deducibles.

Ahora bien, desde el año 1968, se recogía expresamente en el inciso j) del artículo $38^{\circ}$ del Decreto Supremo $N^{\circ}$ 287-68-HC, Ley del Impuesto a la Renta, la deducción de los castigos por deudas incobrables y las previsiones equitativas por el mismo concepto, siempre que se determinen las cuentas a las que correspondan. Respecto del castigo, este dispositivo fue reglamentado mediante Decreto Supremo $\mathrm{N}^{\circ}$ 145-78-EF (1978) en el cual se establecía, que para efectuar el castigo se requería cumplir con los siguientes requisitos:

a) Las deudas hayan permanecido impagas por un periodo superior a un año, contado a partir de su exigibilidad.

b) Se haya ejercitado las acciones judiciales pertinentes hasta el estado de establecerse la imposibilidad del cobro.

c) El detalle de la provisión figure en el Libro de Inventarios y Balances y, además, se presente, con la Declaración Jurada Anual del Impuesto a la Renta, un Anexo en el que figure el detalle de las cuentas provisionadas así como de la aplicación de las provisiones, efectuada durante el ejercicio.

Agrega la norma, que no se requería acción judicial cuando el monto exigible a cada deudor no excedía diez veces el sueldo mínimo vital mensual en la actividad industrial.

En este punto, cabe precisar que en este periodo aunque no había una regulación expresa para la deducción de provisiones el Tribunal Fiscal entendió que estas seguían siendo deducibles para efectos de la determinación del impuesto a la renta. En efecto, en la RTF N $^{\circ} 10950$ de 1975 el Tribunal Fiscal confirmó un reparo efectuado al cargo a Gastos Generales con abono a la Reserva para Malas Deudas (provisión) ya que se trataba de un asiento global sin detalle y en consecuencia no se cumplía la exigencia señalada en el D.S. $\mathrm{N}^{\circ}$ 287-68-HC, esto es, "de que se determinen las cuentas incobrables a las que corresponden las previsiones". De ello se tiene que se aceptaba como deducible la provisión de cobranza dudosa siempre y cuando cumpliera con estar detallada. Del mismo modo en la RTF N² 23304 de 1990 se levanta un reparo efectuado a la deducción de "Provisión para Cobranzas Dudosas" por considerar que no le resultaban exigibles los requisitos del D.S. $\mathrm{N}^{\circ}$ 145-78-EF (acción judicial) sino los requisitos establecidos en el inciso j) del Art. 38 del D.S. 287-68-HC (provisión). 
Siguiendo con la evolución histórica, con la publicación del Decreto Legislativo N² 200, Ley del Impuesto a la Renta (1981), estableció que son deducibles de las rentas de tercera categoría, “j) Los castigos por deudas incobrables y las provisiones equitativas por el mismo concepto, siempre que se determinen las cuentas a las que responden”, siendo que su reglamento, el Decreto Supremo No 302-82-EFC (1982), estableció por primera vez, reglamentariamente, las causales que daban lugar a considerar una deuda como incobrable a efectos de su provisión:

Artículo $71^{\circ}$.- Para efectuar la provisión para cuentas de cobranza dudosa a que se refiere el inciso j) del artículo $40^{\circ}$ del Decreto(25), se requiere que:

a) Se demuestre la existencia de dificultades financieras del deudor que hagan previsible el riesgo de incobrabilidad, mediante análisis periódicos de los créditos concedidos o por otros medios; o se demuestre la morosidad del deudor mediante la documentación que evidencie las gestiones de cobro luego del vencimiento de la deuda, o el protesto de documentos, o el inciso de procedimientos judiciales de cobranza, o que hayan transcurrido más de doce meses desde la fecha de vencimiento de la obligación sin que ésta haya sido satisfecha; y,

b) La provisión al cierre de cada ejercicio figure en el Libro de Inventarios y Balances en forma discriminada.

La provisión, en cuanto se refiere al monto, se considerará equitativa si guarda relación con la parte o el total si fuera el caso, que con arreglo al inciso a) de este artículo se estime de cobranza dudosa.

Por otro lado, el mismo dispositivo legal también reglamentó los requisitos del castigo, estableciendo a la letra lo siguiente:

Artículo $72^{\circ}$.- Para efectuar el castigo de las cuentas de cobranza dudosa, se requiere que:

a) Hayan sido provisionadas; $y$,

b) Que se haya ejercitado las acciones judiciales pertinentes hasta establecer la imposibilidad de la cobranza, salvo cuando se demuestre que es inútil ejercitarlas o que el monto exigible a cada deudor no exceda de una unidad impositiva tributaria (1 U.I.T.). La exigencia de la acción judicial alcanza, inclusive, a los casos de deudores cuyo domicilio se desconoce, debiendo seguírseles la acción judicial prescrita por el Código de Procedimientos Civiles. 
Son deducibles los castigos de cuentas de cobranza dudosa a cargo de personas domiciliadas, que hayan sido condonadas en vía de transacción, siempre que se demuestre a satisfacción de la Dirección la conveniencia de la transacción. Si el deudor realiza actividad generadora de rentas de tercera categoría, deberá considerar como ingreso gravable el monto de la deuda condonada.

Nótese, que similar redacción tenemos en la actualidad, es decir, la de considerar a los castigos por deudas incobrables como gasto deducible para efectos de la determinación de la renta neta imponible, y de regular vía Reglamento los requisitos para su deducibilidad.

En este punto es importante tener en cuenta que hasta el año 1999 no se reguló ni en la Ley ni en el Reglamento del Impuesto a la Renta los castigos de provisiones deducibles para crédito otorgados por empresas del sistema financiero siendo que recién con la dación del Decreto Supremo $\mathrm{N}^{\circ}$ 194-99-EF, vía reglamento, se incorpora los requisitos del referido castigo bajo el siguiente texto:

Tratándose de Empresas del Sistema Financiero, éstas podrán demostrar la imposibilidad de ejercitar las acciones judiciales por deudas incobrables, cuando el Directorio de las referidas empresas declare la inutilidad de iniciar las acciones judiciales correspondientes. Dicho acuerdo deberá ser ratificado por la SBS, mediante una constancia en la que certifique que las citadas empresas han demostrado la existencia de evidencia real y comprobable sobre la irrecuperabilidad de los créditos que serán materia del castigo. La referida constancia será emitida en el ejercicio gravable en el cual se efectúe el castigo. De no emitirse la constancia en dicho ejercicio, no procederá el castigo.

Este párrafo fue sustituido en el año 2004 mediante el Decreto Supremo № 134-2004EF, cuyo texto es el siguiente:

Tratándose de empresas del Sistema Financiero, éstas podrán demostrar la imposibilidad de ejercitar las acciones judiciales por deudas incobrables, cuando el Directorio de las referidas empresas declare la inutilidad de iniciar las acciones judiciales correspondientes. Dicho acuerdo deberá ser ratificado por la SBS, mediante una constancia en la que certifique que las citadas empresas han demostrado la existencia de evidencia real y comprobable sobre la irrecuperabilidad de los créditos que serán materia del castigo. La referida constancia será emitida dentro del plazo establecido para la presentación de la declaración jurada anual del ejercicio al que corresponda el castigo o hasta la fecha en que la empresa hubiera presentado dicha 
declaración, lo que ocurra primero. De no emitirse la constancia en los referidos plazos, no procederá el castigo.

Lo que no se explica en las modificaciones reglamentarias expuestas en materia de castigos de créditos otorgados por entidades financieras es el efecto que supone el incumplimiento de las reglas del castigo. Lo anterior se agrava más aun considerando que para este tipo de provisiones (las reguladas en el inciso h) de la LIR) la Ley no ha hecho referencia alguna a sus respectivos castigos en contraposición con lo regulado para el caso de otras deudas de cobranza dudosa (inciso i) del artículo $37^{\circ}$ de la LIR). Es el reglamento el que condiciona a las empresas comprendidas en los alcances del inciso h) del artículo $37^{\circ}$ de la Ley a los requisitos que establece el inciso g) del artículo $21^{\circ}$ del citado Reglamento, para efectos de su castigo.

En resumen, de lo reseñado hasta este punto tenemos que en materia de incobrables inicialmente se regulaba la deducción de una reserva para malas deudas (inciso d. del artículo $20^{\circ}$ de la Ley $\mathrm{N}^{\circ}$ 7904) siendo que jurisprudencialmente se aceptó también la deducción de castigos directos sin que previamente se haya efectuado una reserva (RTF N ${ }^{\circ}$ 521-1964 y 3677-1968). Posteriormente la nueva Ley del Impuesto a la Renta de 1968, aprobada mediante D.S. N 378-1968-EF reguló expresamente la deducción de castigos siendo en esta época que surge reglamentariamente la provisión como requisito previo al castigo. Jurisprudencialmente en esta época también se aceptó la deducción de provisiones por equipararlas al término "previsiones" (RTF N 109501975, 15777-1980 y 23304-1990). Finalmente con el Decreto Legislativo $\mathrm{N}^{\circ} 200$ (1981) y su reglamento, en una regulación que a groso modo nos acompaña hasta hoy, se reguló expresamente la deducción de provisiones y castigos.

De ello podemos inferir que la deducción de castigos para efectos del impuesto a la renta tuvo como origen la aceptación jurisprudencial de los "castigos directos" como deducibles. Ello da lugar a que el legislador introduzca el término "castigos" dentro de la Ley del Impuesto a la Renta. No obstante el reglamentador, a fin de no perder el control tributario de estas deducciones, introduce la provisión detallada como requisito previo de la deducción de castigos. A la postre se regula expresamente la deducción de las provisiones pero al hacerlo el reglamentador no modifica la regulación en torno a los castigos que continúan teniendo como requisito previo a su deducibilidad la constitución de provisiones y que conlleva a las múltiples lecturas que se puede dar en torno al rol de los castigos en la actualidad. 


\subsection{Aspectos doctrinarios}

Según el Diccionario de la Real Academia de Lengua Española una de las acepciones del verbo castigar es "aminorar gastos" (26). En ese mismo sentido el Diccionario Enciclopédico de Derecho Usual de Cabanellas (1989) señala entre las acepciones del castigo la de "disminuir gastos" (p. 101). En el plano local el Diccionario aplicativo para contadores define el castigo como la "eliminación o retiro de la contabilidad de un importe previamente reconocido como activo" (Abanto, Castillo, Bobadilla, Agapito, Romero, Paredes, 2012, p 144). Agrega el referido diccionario que se puede citar como ejemplo, una cuenta por cobrar por la que se agotaron los medios de cobro y que previamente fue registrada en una cuenta de valuación (estimación de cobranza dudosa). En ese caso se elimina tanto la cuenta por cobrar como la cuenta de valuación. Es esta última acepción la que utilizaremos en el presente trabajo.

Ahora bien en el lenguaje contable es posible encontrar la referencia a los denominados "castigos directos". Así las normas de contabilidad pública distinguen en su regulación los procedimientos para efectuar castigos directos e indirectos. En ambos casos se requiere que las deudas hayan sido previamente provisionadas y que la deuda haya permanecido impaga por un periodo no menor a un año contado a partir de su exigibilidad.

La diferencia entre los castigos directos e indirectos, para las normas de contabilidad pública, radica en el monto de la deuda a castigar y la acción de cobranza requerida; siendo que para los castigos directos el monto de la deuda no puede ser mayor a una remuneración mínima vital y la acción de cobranza requerida es la acción administrativa ejecutada hasta establecer la incobrabilidad de la deuda. En el caso de los castigos indirectos se aplica a montos de deuda superiores a una remuneración mínima vital y la acción de cobranza requerida es la acción judicial ejecutada hasta establecer la incobrabilidad de la deuda.

De otro lado en el ámbito tributario empresarial también es posible encontrar referencia a los denominados "castigos directos". A diferencia de lo estipulado en las normas de contabilidad pública, en el ámbito tributario empresarial se identifica el término "castigo directo" como una afectación directa del incobrable contra los

\footnotetext{
${ }^{26}$ http://dle.rae.es/?id=7r3VFda
} 
resultados del periodo, esto es, sin haber realizado previamente la respectiva provisión. De este tipo de castigos se habla en la doctrina comparada como es el caso de Reig, E. (1991) que al comentar la Ley del Impuesto a las Ganancias de Argentina señala que la referida ley contempla el castigo directo como una forma de deducción de los malos créditos, mediante un cargo a pérdidas (p. 518). En el caso del Perú, como vimos en la evolución histórica casuística del impuesto a la renta, el término "castigo directo" se ha identificado como una deducción del impuesto a la renta sin previa provisión (RTF 10950-1975, 15534-1979, entre otros).

En relación a la deducibilidad de los castigos en el impuesto a la renta, García Mullín (1980) señala que:

En el régimen normal de deducciones, las pérdidas que originan los malos créditos provenientes de operaciones comerciales debieran incidir en la determinación de los resultados del ejercicio en que se configura la incobrabilidad. Atendiendo a esa situación, varias leyes del impuesto a la renta admiten que los castigos por créditos incobrables sean computados a efecto de la determinación de la renta neta. Sin perjuicio de ello, es frecuente que esas leyes autoricen a la empresa a formar fondos destinados a hacer frente a aquellas contingencias. En estos casos, las empresas deducen parte de sus utilidades para constituir el fondo y al producirse la incobrabilidad, las pérdidas son absorbidas por aquél y sólo afectan a los resultados del ejercicio en la parte no cubierta por el mismo.

Agrega el autor que, dentro de ese concepto genérico, algunos países distinguen entre "previsiones" y "provisiones", siendo las primeras aquellos cargos que incidirán necesariamente en la cuenta de ganancias y pérdidas, en los cuales el monto es incierto pero que puede ser calculado estimativamente. Provisiones serían en cambio (en las legislaciones que distinguen entre ambos conceptos) aquellos cargos ciertos y de cálculo exacto que deben gravitar en los resultados del ejercicio, pero que no constituyen obligaciones exigibles a la fecha de balance (p. eje.: provisiones para impuestos y cargas sociales) (p. 177).

Ahora bien, en lo que se refiere a las empresas del sistema financiero, éstas podrán deducir como gasto de la renta bruta las provisiones que haya generado, tal como lo vimos en el capítulo anterior. Sin embargo, para Bouroncle Maldonado (2010)' ello no ocurre en el caso de los castigos pues el efecto es neutro mientras se cumplan con los requisitos para su configuración (p. 903). En efecto, no es que el castigo se deduzca como gasto pues lo fue la provisión que lo generó. Ahora bien, si el castigo no reúne los 
requisitos señalados en la norma tributaria, según este autor, el importe castigado debería agregarse a la renta del contribuyente.

Para Picón Gonzales (2004) señala que si bien la primera condición que tiene el castigo para ser aceptado tributariamente es que previamente haya sido provisionado, es la provisión y no el castigo lo que genera una deducción para calcular la renta neta. Añade que la importancia de cumplir con los requisitos establecidos en las normas tributarias para el castigo de las cuentas por cobrar o colocaciones es que un indebido castigo podría neutralizar el efecto tributario de una provisión (p. 195).

Otro sector de la doctrina (Actualidad Empresarial, 2013) ha considerado que:

La provisión por cobranza dudosa no configura todas las reglas para la deducción del gasto, el momento en que el gasto surte sus efectos no es otro que el ejercicio en que se realiza la referida provisión, siendo el ejercicio en que se cumplen las reglas para el castigo, una suerte de confirmación de un gasto ya tomado en un ejercicio precedente (en el momento de la provisión de cobranza dudosa). No obstante, si las reglas para la confirmación del gasto, el castigo, no se llegasen a cumplir, en ese ejercicio se debe realizar la adición del gasto ya tomado (p. 9).

Frente a este contexto, existen dos problemáticas que deben ser analizadas:

1. La mala o desfasada técnica legislativa que recoge la Ley del Impuesto a la Renta, que califica a los castigos por créditos incobrables como gastos susceptibles de ser deducidos para efectos de la determinación de la renta neta imponible, en la medida, claro está, que se cumplan con los requisitos exigidos en la norma.

Como vimos el castigo contablemente no es una operación que afecte los resultados del ejercicio, por consiguiente, es incorrecta la denominación que le otorga la LIR, de ser un gasto deducible para efectos de la determinación de la renta neta imponible, cuya única explicación estaría dado para las empresas que realicen los denominados "castigos directos".

2. Bajo la teoría de que los gastos por provisiones de crédito y de cobranza dudosa tendrían que pasar por un doble filtro para efectos de su deducción, el primero que le asiste por su propia naturaleza como provisión del gasto, y el segundo que implica cumplir con los requisitos del castigo. 
Se tiene que, si una empresa cumpliera con todos los requisitos exigidos en la Ley y Reglamento de Renta para la deducción de la provisión del gasto el llamado primer filtro-, pero, a su vez no lograra cumplir con los requisitos exigidos para el castigo -el llamado segundo filtro-, la consecuencia tributaria sería, la adición vía declaración jurada anual, del importe correspondiente al gasto por concepto de provisiones para créditos y cobranza dudosa, la misma que fue deducido legalmente en un ejercicio previo.

Bajo este panorama, el objetivo de este trabajo es hacer notar las deficiencias $\left({ }^{27}\right)$ y los vacíos que presenta nuestra legislación nacional, que ha conllevado a un sector del país a transferir su cartera castigada a terceros o, lo que es peor, a empresas vinculadas, con la finalidad de hacer deducible el costo nominal de los créditos vía este mecanismo, y con ello evitar cumplir con los requisitos especiales que le asiste por su naturaleza, ya sea por resultar de imposible cumplimiento o por la onerosidad de su cumplimiento.

\subsection{Regulación tributaria de los castigos de créditos}

El tercer párrafo del inciso e) del artículo $21^{\circ}$ del Reglamento de la LIR señala que las empresas comprendidas en el alcance del inciso h) del artículo $37^{\circ}$ de la LIR, aplicarán para efectos del castigo, lo dispuesto en el inciso g) de este artículo, en cuanto le fuera pertinente.

Por su parte el inciso g) del artículo $21^{\circ}$ del citado Reglamento al regular los castigos de deudas de cobranza dudosa establece que:

Para efectuar el castigo se requiere que la deuda haya sido provisionada y se cumpla, además, con ejercitar las acciones judiciales pertinentes hasta establecer la imposibilidad de la cobranza, salvo cuando se demuestre que es inútil ejercitarlas o que el monto exigible a cada deudor no exceda de tres (3) UIT. Siendo que la exigencia de la acción judicial alcanza, inclusive, a los casos de deudores cuyo domicilio se

27 Es interesante resaltar en la Resolución del Tribunal Fiscal N ${ }^{\circ}$ 5736-5-2003, la recurrente como uno de sus argumentos hizo alusión a la ilegalidad del inciso g) del artículo $21^{\circ}$ del Reglamento de la LIR puesto que no cabía su aplicación, habiéndose circunscrito la interpretación normativa al inciso i) del artículo $37^{\circ}$ de la LIR para su calificación como deuda que no tenía la naturaleza de incobrable, sin embargo, el Tribunal no se pronunció al respecto por considerar que no cabía su aplicación al caso concreto. 
desconoce, debiendo seguírseles la acción judicial prescrita por el Código Procesal $\operatorname{Civil}\left({ }^{28}\right)$.

Agrega que, tratándose de empresas del sistema financiero, éstas podrán demostrar la imposibilidad de ejercitar las acciones judiciales por deudas incobrables, cuando el Directorio de las referidas empresas declare la inutilidad de iniciar las acciones judiciales correspondientes. Dicho acuerdo deberá ser ratificado por la SBS, mediante una constancia en la que certifique que las citadas empresas han demostrado la existencia de evidencia real y comprobable sobre la irrecuperabilidad de los créditos que serán materia del castigo ${ }^{(29)}$. Añade que la referida constancia será emitida dentro del plazo establecido para la presentación de la declaración jurada anual del ejercicio al que corresponda el castigo o hasta la fecha en que la empresa hubiera presentado dicha declaración, lo que ocurra primero. De no emitirse la constancia en los referidos plazos, no procederá el castigo ${ }^{(30)}$.

Nótese, que transcurrido este plazo el cumplimiento del citado requisito, se vuelve un hecho de imposible cumplimiento, ya que como veremos más adelante la SBS no emite Constancias de Irrecuperabilidad transcurrido dicho plazo.

En efecto, en opinión de Bouroncle Maldonado (2010) considera que el distinto tratamiento legal en la acreditación de la irrecuperabilidad de la deudas de cobranza

28 Sobre el particular, cabe mencionar que en el Informe $\mathrm{N}^{\circ}$ 134-2001-SUNAT/K00000, se concluye que para efectuar el castigo por deudas incobrables se requiere, entre otros requisitos, que el contribuyente acredite mediante el ejercicio de las acciones judiciales pertinentes que la deuda es efectivamente incobrable.

Lo señalado en el párrafo anterior no es de aplicación cuando el importe de la deuda exigible a cada deudor no es mayor a 3 UIT o cuando se acredita que es inútil ejercitar las referidas acciones judiciales.

Añade que, aun cuando el deudor tributario se encuentre ante alguna de las situaciones que se enumeran en la presente consulta y cuente con la documentación que en ella se señala, debe analizarse el caso particular de cada deudor tributario, por lo que no es posible, a priori, emitir pronunciamiento sobre si los documentos que se señalan en la consulta sustentan la imposibilidad judicial de la cobranza o la inutilidad de ejercitar las referidas acciones judiciales, para el castigo por deudas incobrables.

29 Conforme a lo establecido en el primer párrafo del numeral 6 del Capítulo IV del Reglamento para la Evaluación y Clasificación del Deudor y la Exigencia de Provisiones, aprobado por Resolución SBS $\mathrm{N}^{\circ}$ 11356-2008 para el castigo de créditos incobrables, el Directorio debe proceder al castigo de un crédito clasificado como Pérdida, íntegramente provisionado, cuando exista evidencia real y comprobable de su irrecuperabilidad o cuando el monto del crédito no justifique iniciar acción judicial o arbitral.

30 Vale la pena mencionar que el inciso f) del artículo $21^{\circ}$ del Reglamento de la Ley del Impuesto a la Renta, fue sustituido por el artículo $13^{\circ}$ del Decreto Supremo $\mathrm{N}^{\circ}$ 134-2004-EF, publicado el 05.10.2004. Así pues, se consideró pertinente ampliar el plazo hasta el vencimiento para la presentación de la declaración anual del Impuesto a la Renta o hasta la presentación de dicha declaración, con lo cual el reglamentador tuvo la oportunidad de revisar el tema. 
dudosa (en especial de los créditos) susceptibles de ser castigadas en las empresas del sistema financiero frente a las empresas del sector no financiero, obedece a que siendo el giro principal de las empresas del sistema financiero el otorgar créditos, la posibilidad de contar con créditos impagos es mucho mayor en éstas, por lo que la legislación tributaria ha resuelto encargar a la SBS la ratificación de los acuerdos del Directorio de las empresas del sistema financiero que aprueben el castigo de deudas incobrables, para lo cual dicha entidad emite las denominadas "Constancias de Irrecuperabilidad".(p. 899)

Considerando lo expuesto, queda claro que la SBS es la entidad encargada de regular y supervisar a las empresas que operen en el sistema financiero y de seguros, siendo ello así, mediante la Circular $\mathrm{N}^{\circ}$ B-2185-2010 dictó las disposiciones relativas a la Constancia de Irrecuperabilidad para el castigo tributario de créditos y cuentas por cobrar al que alude el artículo $21^{\circ}$, literal g) del numeral 1 del Reglamento antes mencionado ${ }^{(31)}$.

Efectivamente, el numeral 2 de la citada Circular enumera los requisitos que se debe presentar a la SBS para la emisión de la Constancia de Irrecuperabilidad, para lo cual deberán presentar a esta Superintendencia una solicitud adjuntando lo siguiente:

a) Copia certificada del Acuerdo del Directorio u órgano equivalente en el que se haya aprobado el castigo de créditos y cuentas por cobrar; El Acuerdo debe hacer referencia expresa de que todos los créditos y cuentas por cobrar incluidos en la solicitud cumplen cada una de las condiciones señaladas en el numeral $2.2\left({ }^{32}\right)$.

31 La Circular $\mathrm{N}^{\circ}$ B-2185-2010, es de aplicación para las empresas comprendidas en los literales A y B del artículo 16 de la Ley General, al Banco de la Nación, el Banco Agropecuario, a la Corporación Financiera de Desarrollo (COFIDE), al Fondo Mivivienda S.A., a las Empresas Administradoras Hipotecarias y al Fondo de Garantía para Préstamos a la Pequeña Industria (FOGAPI), en adelante empresas.

32 Condiciones de los Créditos y Cuentas por Cobrar a castigar, los créditos y cuentas por cobrar objeto de la solicitud de la constancia de irrecuperabilidad deberán cumplir las siguientes condiciones:

a) Tratándose de créditos:

- Monto castigado sea superior a tres (3) Unidades Impositivas Tributarias (UIT);

- Los respectivos deudores estén clasificados en categoría Pérdida;

- El monto castigado correspondiente al capital del crédito se encuentra íntegramente provisionado; y,

- Exista evidencia real y comprobable sobre su irrecuperabilidad.

b) Tratándose de cuentas por cobrar:

- Monto castigado sea superior a tres (3) Unidades Impositivas Tributarias (UIT);

- El monto castigado correspondiente al capital de las cuentas por cobrar se encuentra íntegramente provisionado;

- Las provisiones deben cumplir con los requisitos exigidos en el inciso i) del artículo 37 de la Ley del Impuesto a la Renta, Reglamentado por el inciso f) del artículo 21 del Reglamento de la Ley del Impuesto a la Renta; y, 
b) Un Informe Legal que de manera resumida y agregada, ponga de manifiesto el cumplimiento de las condiciones que sustentan la aprobación del Directorio de los castigos objeto de la solicitud de constancia de irrecuperabilidad. Dicho informe es adicional y distinto de los informes legales individuales que deben estar contenidos en el file del deudor para sustentar la situación de irrecuperabilidad; y,

c) La información específica de los créditos y/o cuentas por cobrar castigados objeto de la solicitud de constancia de irrecuperabilidad, la misma que deberá ser remitida en medios magnéticos (archivo Excel). Dicha información deberá contener: código SBS, nombre completo, monto desagregado por monedas de capital e intereses y otros conceptos castigados, fecha de castigo, total deuda castigada, provisiones, garantías y la clasificación correspondiente.

De lo expuesto se desprende que, en el caso de las empresas del sistema financiero, la regla mencionada en los párrafos anteriores permite que la imposibilidad de la cobranza pueda ser certificada por la SBS, lo que ofrece una credibilidad objetiva al contar con un documento emitido por una entidad seria evitando la subjetividad que supone que el propio deudor declare la irrecuperabilidad por sus propios medios sin que nadie respalde o confirme esta situación.

Como fluyen de las normas citadas, se puede afirmar que para que surta efecto tributario el castigo de las citadas cuentas que efectúen las empresas del sistema financiero, se requiere en primer lugar que la deuda haya sido provisionada $\left({ }^{33}\right)$, y, para el caso que el monto exigible a cada deuda exceda de 3 UIT se cuente con la Constancia de Irrecuperabilidad que para tal efecto emitirá la SBS.

- Exista evidencia real y comprobable sobre su irrecuperabilidad.

El monto castigado incluye capital, intereses compensatorios y moratorios, comisiones, gastos y otros conceptos derivados de la relación obligacional.

33 Debe señalarse que de acuerdo al criterio vertido por el Tribunal Fiscal en la RTF N ${ }^{\circ}$ 06911-3-2010, señala que para que sea deducible la provisión de deudas de cobranza dudosa es obligatorio que la provisión figure al cierre del ejercicio en el Libro de Inventarios y Balances, por lo que no resulta posible que en un mismo ejercicio gravable se realicen la provisión y el castigo, dado que mediante este último las cuentas de cobranza dudosa desaparecen del balance y por ende no podrían ser mostradas en el balance al cierre del ejercicio, impidiéndose el control tributario. 


\subsection{Regulación pertinente de la Superintendencia de Banca y Seguros}

El artículo $2^{\circ}$ de la Resolución Ministerial $N^{\circ}$ 625-2004-EF-10 $\left({ }^{34}\right)$ dispone que las provisiones que cumplen conjuntamente los requisitos señalados por el inciso h) del artículo $37^{\circ}$ de la LIR, reglamentado por el inciso e) del artículo $21^{\circ}$ del Reglamento de la LIR, son las que se señalan a continuación:

a) Resolución SBS No 808-2003, modificada por la Resolución SBS N ${ }^{\circ}$ 1343$2003\left({ }^{35}\right)$ : Aprueban Reglamento para la Evaluación y Clasificación del Deudor y la Exigencia de Provisiones.

b) Resolución SBS No 1114-99, modificada por la Resolución SBS N ${ }^{\circ} 1227$ 2002 $\left({ }^{36}\right)$ : Aprueban Reglamento de transferencia y adquisición de cartera crediticia.

Así pues, de acuerdo con el Numeral 1 del Capítulo II del Reglamento para la Evaluación y Clasificación del Deudor y la Exigencia de Provisiones el deudor, aprobado por la Resolución SBS N 11356-2008 (antes Resolución SBS N 808-2003), y normas modificatorias, se establece las categorías de clasificación crediticia del deudor de la cartera de crédito de acuerdo a las siguientes categorías:

- Categoría Normal (0)

- Categoría con Problemas Potenciales (1)

- Categoría Deficiente (2)

- Categoría Dudoso (3)

- Categoría Pérdida (4)

Por su parte, el numeral 6 del Capítulo IV del citado Reglamento señala que "el Directorio debe proceder al castigo de un crédito clasificado como Pérdida, íntegramente provisionado, cuando exista evidencia real y comprobable de su

34 Norma que precisan provisiones que cumplen requisitos señalados por el inciso h) del artículo $37^{\circ}$ de la Ley del Impuesto a la Renta (2004).

35 Cabe precisar que de conformidad con el Artículo 3 de la Resolución Ministerial № 693-2010-EF-15, publicada el 30 diciembre 2010, la referencia a la Resolución SBS No 808-2003, modificada por la Resolución SBS No 1343-2003, contenida en la presente Resolución Ministerial, debe entenderse que corresponde a la Resolución SBS N 11356-2008, modificada por la Resolución SBS Nº 14353-2009, respecto a las mismas provisiones contempladas en el presente inciso.

${ }^{36}$ Resolución dejada sin efecto por la Resolución SBS N ${ }^{\circ}$ 1308-2013, norma que aprueban el nuevo Reglamento de Transferencia y Adquisición de Cartera Crediticia. 
irrecuperabilidad o cuando el monto del crédito no justifique iniciar acción judicial o arbitral"' $\left({ }^{37}\right)$.

En el referido Reglamento se añade que "la empresa deberá fijar dentro de sus políticas de control interno, los procedimientos y medidas necesarias para llevar a cabo el castigo de sus cuentas incobrables, quedando evidenciados en las actas respectivas del Directorio u órgano equivalente".

A su vez indica que "los créditos castigados deben ser reportados por las empresas en el Anexo No 6 "Reporte Crediticio de Deudores - RCD" y serán mantenidos en la Central de Riesgos hasta que sean transferidas, condonadas o se hayan

$37 \mathrm{Al}$ respecto, se tienen que los criterios generales a tener en cuenta para la clasificación crediticia del deudor son:

a) La clasificación crediticia del deudor está determinada principalmente por la capacidad de pago del deudor, a través de su flujo de caja y el grado de cumplimiento de sus obligaciones. Asimismo, deben tomarse en consideración su solvencia, las clasificaciones crediticias asignadas por otras empresas del sistema financiero, así como su historial crediticio, entre otros elementos prudenciales.

b) Sólo se considerará el cumplimiento de las obligaciones del deudor como parámetro válido cuando los fondos utilizados para tal fin sean generados por el propio deudor y no sean flujos financiados directa o indirectamente por terceros. Tampoco se considerarán tales cumplimientos como parámetros válidos cuando constituyan una simple instrumentación contable, sin que medien ingresos reales. Estos criterios serán de aplicación general, incluso en los casos de operaciones objeto de alguna refinanciación o reestructuración, así como de aquellos arrendamientos financieros que tuvieron su origen en otros créditos.

c) En caso que el deudor tenga varios créditos en la misma empresa, su clasificación será la correspondiente a la categoría de mayor riesgo, a menos que el saldo en dichos créditos sea menor a S/. 100.00 (Cien Nuevos Soles) o al uno por ciento (1\%) del total de la deuda con la empresa (con un tope máximo de tres (3) Unidades Impositivas Tributarias (UIT)), el que resulte mayor. La empresa primero consolidará la clasificación correspondiente al deudor por modalidad de crédito aplicando el criterio señalado anteriormente; luego consolidará las distintas modalidades por tipo de crédito, aplicando el mismo criterio.

d) En caso el deudor tenga créditos en dos o más empresas del sistema financiero o, en general, en cualquier patrimonio que deba reportar el Anexo No 6 "Reporte Crediticio de Deudores-RCD", el deudor será clasificado a la categoría de mayor riesgo que le haya sido asignada por cualquiera de las entidades cuyas acreencias representen un mínimo del veinte por ciento $(20 \%)$ en el sistema. La revisión de la clasificación así efectuada se designará en los párrafos subsiguientes, como "alineamiento". Sólo se permitirá un nivel de discrepancia con respecto a esta categoría.

e) La entidad deberá efectuar el procedimiento del alineamiento en forma mensual, considerando la clasificación del deudor en base a la última información disponible remitida por esta Superintendencia a través del "Reporte Crediticio Consolidado - RCC". La entidad deberá reportar igualmente la clasificación sin alineamiento en el campo asignado en el "Reporte Crediticio de Deudores - RCD".

f) Para fines de los literales c) y d) se considerará a los créditos directos y a los créditos indirectos, excepto los créditos no desembolsados y las líneas no utilizadas.

g) Para efecto del alineamiento se deberá considerar a:

i. Las carteras de créditos mantenidas por empresas del sistema financiero, incluidas las carteras castigadas que mantengan las empresas del sistema financiero y las carteras de créditos de las empresas del sistema financiero en liquidación;

ii. Las carteras de créditos que hayan sido transferidas mediante fideicomiso u otro contrato similar, siempre que conforme con el Reglamento del Fideicomiso y de las Empresas de Servicios Fiduciarios, exista obligación de seguir reportando en el RCD."

iii. Las carteras de créditos transferidas que conforme el Reglamento de transferencia y adquisición de cartera se encuentren obligados a seguir reportando en el RCD. 
superado los motivos que dieron lugar a su castigo, de acuerdo a lo informado por la empresa correspondiente".

A continuación presentamos la dinámica contable que establece sobre este tema el Capítulo V del Manual de Contabilidad $\left({ }^{38}\right.$ ) para las Empresas del Sistema Financiero:

Cuenta 8103: Cuentas Incobrables Castigadas.- En esta cuenta se registran los derechos de la empresa que han sido castigados, independientemente del castigo tributario que se realice conforme las normas vigentes. Dichas deudas castigadas deben permanecer registradas en esta cuenta hasta que sean transferidas, condonadas o sean superados los motivos que dieron lugar a su castigo. El procedimiento de castigo deberá ser fijado dentro de las políticas de control interno de la empresa.

Añade el Manual que el saldo del capital de los créditos que se castigan según lo establecido en el Reglamento para la Evaluación y Clasificación del Deudor y la Exigencia de Provisiones, debe registrarse en la subcuenta 8103.02; mientras que los intereses y comisiones de dichos créditos castigados deben registrarse en la cuenta analítica 8103.04.02 y la cuenta analítica 8103.05.02, respectivamente.

Por otra parte, en caso los deudores de créditos castigados sean refinanciados o reestructurados, según los criterios del Reglamento para la Evaluación y Clasificación del Deudor y la Exigencia de Provisiones, dicha operación refinanciada o reestructurada deberá registrarse en las cuentas correspondientes de créditos refinanciados o reestructurados, con abono a las cuentas respectivas de ingresos diferidos de operaciones refinanciadas y reestructuradas. Simultáneamente el monto de la deuda que se refinancia o reestructura (capital e intereses) deberá extornarse de la cuenta 8103. Por lo tanto, un crédito vencido o en cobranza judicial que habiendo sido castigado, posteriormente sea reestructurado o refinanciado, deberá ser activado (cuentas 1403 ó 1404) con el consecuente efecto en la clasificación y requerimiento de provisiones.

Aquellos créditos castigados donde no medie algún acuerdo de refinanciación o reestructuración, pero que vengan siendo amortizados, serán reclasificados a la subcuenta 8109.25 “Créditos castigados que vienen siendo amortizados", debiendo ceñirse a los criterios de clasificación establecidos en el Reglamento para la Evaluación y Clasificación del Deudor y la Exigencia de Provisiones.

En ese sentido la dinámica contable es:

38 http://www.sbs.gob.pe/principal/categoria/bancos-financieras-y-otros/117/c-117 


$\begin{array}{ll}\text { Débitos (se carga) - } & \text { Por el importe de los derechos castigados. } \\ \text { Créditos (se abona) - } & \text { Por la cancelación, refinanciación, reestructuración, } \\ & \text { transferencia, condonación o cualquier otra modalidad } \\ & \text { de extinción de los derechos castigados }\end{array}$

Sobre el particular, en la Resolución del Tribunal Fiscal N 15081-1-2013 dentro de los argumentos que la recurrente menciona que para el caso de las empresas del sistema financiero, los castigos no corresponden realmente a castigos conforme al concepto contable tradicional y tampoco al concepto tributario de castigo de cuentas incobrables, pues estos implican la eliminación de las cuentas por cobrar y de sus respectivas provisiones, lo que no ocurre en estos casos, por lo tanto, al no haberse eliminado las cuentas por cobrar y sus respectivas provisiones sino que simplemente se reclasifican a una cuenta de orden, no se encuentra dentro de lo descrito en el inciso i) del artículo $37^{\circ}$ del TUO de la LIR.

Agrega la recurrente, que mantiene una clara identificación tanto contable como operativa respecto de los créditos considerados como castigados desde el punto de vista de la Ley del Impuesto a la Renta y su Reglamento, que controla en subcuentas separadas aquellos créditos que si deben ser considerados como castigados y aquellos que solamente corresponden a un mero traslado de cuentas sin efectos tributarios y que la diferencia es que los créditos castigados tributariamente son, entre otros, aquellos respecto de los cuales se han agotado las acciones de cobranza, mientras que los no castigados tributariamente y que han sido reclasificados de acuerdo a los criterios de la SBS, son aquellos respecto de los cuales se siguen las acciones de cobranza.

Finalmente, toca un tema importante que lo hemos desarrollado anteriormente, que no existe ninguna disposición en la Ley del Impuesto a la Renta o en su Reglamento que establezca que la consecuencia de que el castigo de un crédito no sea aceptado tributariamente sea la no deducibilidad de la provisión de cobranza dudosa que pudiera haberse registrado previamente.

Al respecto, el Tribunal Fiscal después de analizado el tema señala que, la provisión por deudas incobrables en empresas del sistema financiero, constituye una de las provisiones admitidas por la Ley del Impuesto a la Renta, estando sujeta su deducción al cumplimiento de ciertos requisitos; y a su vez, para que proceda el castigo por deudas incobrables, estas deudas, entre otros requisitos, tienen que haber sido 
previamente provisionadas y que los respectivos deudores estén clasificados en categoría pérdida.

Agrega, si bien la cuenta contable 8103 permite un control interno para la entidad financiera de las cuentas incobrables castigadas y de acuerdo con el importe de la variación referenciado, dicho monto podría abarcar el registro de castigos de deudas incobrables de diferentes ejercicios económicos, y no solamente del periodo materia de acotación o diferir del monto realmente castigado en las cuentas del Balance; por ello correspondía que la Administración Tributaria analizará el castigo de las cuentas incobrables, en una cuenta del balance como sería la cuenta 1409 - Provisión para créditos; situación que no realizó en el presente caso, por lo que no se encuentra sustentado fehacientemente que los montos consignados en la cuenta 8103 que sirvieron de base inicial a la Administración para efectuar el reparo de las provisiones deducidas, coincidieran con los importes castigados en las cuentas contables colocaciones de cuentas por cobrar del Balance General respecto al ejercicio acotado.

Por otro lado, indica que no se aprecia que la Administración hubiese verificado que las cuentas provisionadas, que son materia de reparo, correspondieran efectivamente a las cuentas que considera indebidamente castigadas en dicho ejercicio; a efectos de desconocer el gasto por la provisión de incobrables, pues no se ha efectuado el detalle de las deudas y montos que supuestamente fueron materia de provisión y posterior castigo en dicho ejercicio. Nótese que fluye del caso, que se realizó la provisión y el castigo en el mismo ejercicio, con lo cual, el Tribunal Fiscal exhorta a la Administración que realice previamente el detalle de las cuentas que fueron materia de provisión y deducción, de tal manera que el reparo se encuentre debidamente sustentado.

Con esta posición el Tribunal Fiscal al parecer estaría confirmando implícitamente la teoría de que el castigo tiene efecto en la determinación de la renta neta imponible, y su incumplimiento tendría consecuencias tributarias, esto es, adicionar el gasto de la provisión por no contar con la Constancia de Irrecuperabilidad de Créditos emitida por la SBS, tanto es así que la Administración Tributaria procedió a reparar el importe de las provisiones realizadas por la incobrabilidad de créditos y cuentas por cobrar. 
Es importante destacar que dentro de los argumentos de la Administración Tributaria, se encuentra la norma reglamentaria y lo señala de manera expresa en el Resultado de su Requerimiento, al indicar que “ (...) el contribuyente al contabilizar el retiro de colocaciones y de cuentas por cobrar del Balance General y transferirlas a cuentas de orden; financieramente y tributariamente realizó el castigo de las mismas y al no contar con la constancia de irrecuperabilidad de créditos, las provisiones realizadas durante el ejercicio 2004 de colocaciones y cuentas por cobrar no eran aceptables tributariamente, de conformidad con lo dispuesto en el último párrafo del numeral 1 del inciso g) del artículo $21^{\circ}$ del Reglamento de la LIR”. No obstante a ello, el Tribunal Fiscal no se pronuncia al respecto, incluso siendo uno de los puntos tocados por la recurrente en su recurso de Apelación.

En línea con lo anterior, vale la pena indicar que en la Resolución del Tribunal Fiscal $N^{\circ}$ 6911-3-2010 se ha establecido que de las normas del impuesto a la renta para que sea deducible la provisión de deudas de cobranza dudosa es obligatorio que la provisión figure al cierre del ejercicio en el Libro de Inventarios y Balances, por lo que no resulta posible que en un mismo ejercicio gravable se realice la provisión y el castigo, dado que mediante este último las cuentas de cobranza dudosa desaparecen del balance y por ende no podrían ser mostradas en el balance al cierre de cada ejercicio impidiéndose el control tributario, por lo que resulta procedente el reparo formulado por la Administración.

En tal sentido, de cara a estas Resoluciones se puede concluir que en opinión del Tribunal Fiscal los requisitos del castigo, que se encuentran en el Reglamento de la LIR, deben ser cumplidos a efectos de confirmar la provisión de créditos realizados anteriormente, por lo que su incumplimiento conllevaría a un adición en la determinación del impuesto a la renta, equivalente al importe de su provisión. No obstante a ello, lo criticable de estas resoluciones es que el Tribunal Fiscal no hace un análisis de legalidad respecto del inciso i) del artículo $37^{\circ}$ de la LIR puesto que al reconocerse la posibilidad de deducir provisiones y castigos no podría luego, vía reglamento, desconocerse esta posibilidad limitando sólo la deducción a las provisiones.

El argumento del control fiscal por el que previo a todo castigo siempre debe existir una provisión y que esta figure al cierre del balance del año respectivo no puede llevar a desconocer que el castigo per se es un concepto legalmente deducible. En todo caso, si el requisito fuera el control fiscal el reglamentador podría implementar otros 
medios para hacerlo y no el requerimiento de una provisión previa al castigo porque al haberlo hecho ha restringido las posibilidades de deducciones que la Ley reconoce.

\subsection{Diferencia entre el tratamiento contable y tributario}

Como se ha visto en el punto anterior, la SBS contiene normas claras y puntuales que regulan los castigos de créditos por las empresas del sistema financiero, diferentes a las establecidas por las normas tributarias.

Al respecto, en el Oficio $\mathbf{N}^{\circ}$ 41041-2014-SBS de fecha 06.11.2014, la SBS emite opinión respecto a la procedencia de efectuar el castigo de cuentas incobrables y créditos para fines contables y financieros, y señala que el Reglamento para la Evaluación y Clasificación del Deudor y la Exigencia de Provisiones, contenía disposiciones para realizar el castigo contable y financiero de créditos incobrables. Agrega que, estas normas no dictan un tratamiento para el castigo de créditos incobrables con fines tributarios, por ser prácticas con objetivos distintos (el subrayado es nuestro). Por lo tanto, la SBS no encuentra inconveniente en proceder con un castigo de créditos incobrables para fines contables y financieros, cuando se cumpla lo señalado con el Reglamento para la Evaluación y Clasificación del Deudor y la Exigencia de Provisiones, aun cuando no se cuente con la Constancia de Irrecuperabilidad que se menciona en el Reglamento de la LIR.

Por otro lado, señala que en el Reglamento para la Evaluación y Clasificación del Deudor y la exigencia de provisiones se indica que los créditos castigados deben ser controlados contablemente en las cuentas respectivas destinadas para su registro. Para este fin, en el Manual de Contabilidad para las empresas del sistema financiero, en las cuentas de orden o control, se incluye la cuenta 8103 "Cuentas Incobrables Castigadas"; en tal sentido, mediante el registro de esta cuenta, se contabiliza el monto de los créditos y cuentas por cobrar que han sido materia del castigo $\left({ }^{39}\right)$.

Ahora bien, la legislación del Impuesto a la Renta no ha definido lo que debe entenderse por "castigo", siendo éste un concepto contable resulta pertinente recurrir a la definición establecida por la SBS en su glosario de términos e indicadores

39 Cabe señalar, como lo hemos visto anteriormente el procedimiento de castigo debe ser fijado dentro de las políticas de control interno establecidas por la empresa. 
financieros, el mismo que señala que los créditos castigados son aquellos clasificados como pérdida, íntegramente provisionados, que han sido retirados de los balances de las empresas.

A decir de Bouroncle Maldonado (2010):

No existe en la normatividad una definición que establezca lo que es un castigo, lo cual no nos impide de poder ensayar una a riesgo, por cierto, de que sea insuficiente y que encierre posibles errores u omisiones. Pues bien, el castigo es un mecanismo por el cual una empresa reconoce la imposibilidad de la cobranza de una o varias acreencias previamente provisionadas, lo que conlleva a que no sean consideradas como activos de la empresa, pero que sin embargo, y en lo que se refiere a las empresas supervisadas por la SBS, deban ser controladas contablemente en los registros correspondientes (mediante cuentas de orden).

Agrega el autor que, el retiro de una o varias acreencias del activo de una empresa del sistema financiero por haber sido castigadas, supone una eventual ventaja para ésta en términos de una disminución de la morosidad de su cartera de cobros, lo cual abona en una mejora de su rentabilidad al no tener que realizar provisiones por deudas morosas que deban ser deducidas de su renta. (p 903)

En efecto, al efectuar el castigo de un activo financiero en la dinámica contable intervienen: un cargo a la cuenta de activo por la estimación que originó el deterioro y un abono al activo financiero original por el mismo importe, que al netearse generan la desaparición del activo del Balance General. Nótese de lo expuesto, que el castigo no es una operación que afecte los resultados del ejercicio que originen una disminución en la renta neta de tercera categoría, salvo que se realice un "castigo directo" que no es el caso.

Queda claro entonces que, para efectos tributarios, la norma al exigir el cumplimiento de ciertos requisitos, lo que busca con el castigo es que no se pierda el control tributario de las cuentas que lo originan, de tal manera que si en un futuro se procediera con su recuperación se pueda establecer la correlación entre los conceptos que formaron su provisión.

Así por ejemplo, en el supuesto que el contribuyente castigue deudas cuya provisión de incobrabilidad no fue aceptada tributariamente y en ejercicios posteriores se genera un ingreso por su recuperación, resultaría lógico que se deduzca de la renta neta imponible del impuesto a la renta el importe contabilizado como ingreso, y con 
ello evitar tributar doblemente por el mismo concepto, situación distinta si la provisión fuera aceptada tributariamente dicho ingreso sería materia de tributación. Criterio recogido en las Resoluciones del Tribunal Fiscal $N^{\circ}$ 7454-2-2004, 1164-2-2004 y 10569-3-2012.

Ahora bien, bajo el supuesto que el incumplimiento de las disposiciones para que el castigo de créditos y cuentas por cobrar tengan efecto tributario, de ello no se podría afirmar que el activo financiero vuelva a tener contenido económico, pues es indiscutible que la disminución de su valor se originó al momento de la provisión y no en un momento posterior como es el castigo.

Más allá de la técnica legislativa, que como se ha indicado, es que la norma lo trata como un gasto -aun cuando no tiene esa naturaleza contablemente-, resultaría errado perder el derecho a la deducción de un gasto por no contar con un requisito formal y más si es ajeno a la voluntad del contribuyente, por lo que creemos que no se debería generar ningún efecto tributario en la base imponible del impuesto a la renta por efectuar el castigo sin contar con la Constancia de Irrecuperabilidad cuando el gasto de la provisión haya sido deducida correctamente.

Finalmente, como hemos visto en la evolución histórica desde 1934 hasta la actualidad, siempre se ha regulado en un apartado distinto las deducciones por incobrables para las empresas del sistema financiero siendo que en el texto vigente de la Ley del Impuesto a la Renta el legislador ha dispuesto que resultan deducibles las provisiones específicas que cumplan los requisitos establecidos por Ley. Nótese que a diferencia de lo establecido para otras deudas de cobranza dudosa, el legislador no ha dispuesto en la Ley la deducción de castigos para el caso de empresas del sistema financiero.

En ese sentido, en cualquier escenario, sea que se adopte la tesis que los castigos son irrelevantes en el impuesto a la renta o que implican un doble filtro para el control tributario, resultaría ilegal la incorporación vía reglamento del cumplimiento de los requisitos del castigo para el caso de las provisiones especificas vinculadas a operaciones de crédito de las empresas del sistema financiero, recogidas actualmente en el inciso h) del artículo $37^{\circ}$ del TUO de la Ley del Impuesto a la Renta. 


\subsection{Tratamiento en la legislación comparada}

De lo revisado en la Legislación Comparada en materia de incobrables se observa lo siguiente:

Todas las legislaciones revisadas contienen normas expresas que, con mayor o menor detalle, regulan las deducciones por deudas incobrables.

Algunas legislaciones como es el caso de Colombia, Argentina, Ecuador y Chile hacen referencia expresa a la deducción de provisiones y/o castigos. En los otros casos se habla de la deducción por créditos incobrables, malos créditos o pérdida de valor por deterioro de créditos.

En los países donde se hace referencia expresa a la deducción de provisiones y/o castigos se tiene lo siguiente:

- La deducción de provisiones se encuentra prohibida o en todo caso, si se acepta, se encuentra limitada porcentualmente.

- La deducción de castigos se encuentra sometida al cumplimiento de requisitos y a la verificación de indicios de incobrabilidad como son la cesación de pagos del deudor, su declaración en quiebra, el inicio de acciones judiciales, etc. Estas causales de incobrabilidad son similares a los supuestos que deben verificarse para admitir como deducible las provisiones por cobranza dudosa en la legislación peruana.

Algunos países como el caso de Chile y México al regular las deducciones por incobrables hacen diferenciaciones en función de los montos de las deudas vencidas siendo que a mayores montos de deuda las exigencias para la deducibilidad son mayores.

En los casos de Colombia, Argentina y Bolivia se acepta la deducción de castigos directos entendidos como una afectación directa a la cuenta de resultados, previo cumplimiento de los requisitos y la verificación de los indicios de incobrabilidad que sus respectivas legislaciones requieren.

De lo anterior se puede concluir que las legislaciones de todos los países, independientemente del nombre atribuido a la perdida por deterioro del valor de los activos financieros, se han preocupado por uniformizar los criterios que se tomaran en cuenta para la deducción del incobrable a efectos del impuesto a la renta evitando así la 
discrecionalidad o subjetividad de los contribuyentes en relación a su evaluación. Estas normas se dirigen a:

- Justificar la incobrabilidad fijando la causal que los produce.

- Tener un control tributario de los incobrables deducidos.

- Vincular su deducción con las operaciones del negocio (causalidad).

Ahora bien en el caso peruano para la deducción de incobrables se ha optado por utilizar la terminología contable: provisiones y castigos. Como vimos en la parte del análisis de castigos y provisiones, en un inicio eran deducibles solamente las reservas para incobrables, luego fueron deducibles los castigos y las previsiones y finalmente se recogió en la legislación vigente hasta ahora la deducción de provisiones y castigos. Con el transcurso del tiempo estos términos fueron dotados de contenido tributario siendo que actualmente la provisión de cobranza dudosa regulada en la ley y el reglamento del impuesto a la renta coincide con lo que en otras legislaciones son los requisitos para el castigo de las deudas incobrables.

Asimismo en la legislación comparada también se permite la deducción de créditos respecto de los cuales se ha confirmado la imposibilidad de cobro lo que en buena cuenta podría identificarse con el agotamiento de las acciones judiciales que exige nuestra legislación para el castigo de créditos.

Cabe precisar que en ninguna legislación revisada se establece un doble control sobre la deducción de incobrables, esto es primero como provisión y luego como castigo.

Finalmente cabe resaltar que además del Perú todos países de la Alianza del Pacífico (Chile, Colombia y México) tienen normas que regulan la deducción de incobrables para el caso de instituciones financieras con diferentes matices:

- Colombia admite una deducción amplia en lo que se refiere a deterioro por pérdida de valor de los créditos siendo que se admite como deducibles la provisión de cartera de créditos y la provisión de coeficiente de riesgo así como las provisiones realizadas durante el respectivo año gravable sobre bienes recibidos en dación en pago y sobre contratos de leasing.

- México por el contrario es muy riguroso en el tratamiento de incobrables para el caso de instituciones de crédito admitiendo solo la deducción de castigos de 
conformidad con las disposiciones establecidas por la Comisión Nacional Bancaria y de Valores, esto es que exista evidencia de que se han agotado las gestiones formales de cobro o determinado la imposibilidad práctica de recuperación del crédito.

- Chile concibe como gasto deducible a toda provisión que efectúen los bancos e instituciones financieras en base a instrucciones dictadas conjuntamente por la Superintendencia de Bancos y la Administración Tributaria (Servicio de Impuestos Internos).

- Las provisiones que son reconocidas como deducibles son aquellas que están relacionadas, por regla general y casi única, con operaciones de crédito.

A mayor abundamiento cabe citar que, inclusive en la legislación comparada, las provisiones constituidas para operaciones de crédito deben cumplir ciertos requisitos que permitan inferir su riesgo de incobrabilidad. La legislación chilena sólo considera como provisiones deducibles aquellas relacionadas a créditos clasificados en las últimas dos categorías de riesgo (a diferencia del Perú donde el crédito puede estar clasificado en cuatro categorías de cinco en total); y, además exige un plazo de permanencia en el tiempo de tal calificación para que proceda la deducción tributaria.

De ello se colige que la legislación extranjera otorga un tratamiento más restrictivo y cuidadoso a la deducibilidad como gasto tributario de la provisión para créditos.

Las provisiones aceptadas como gasto tributario son aquellas relacionadas con operaciones que tienen una alta tendencia la incobrabilidad o las que carecen de garantías o colateral.

Veamos a continuación el siguiente cuadro comparativo: 
Tabla 2.1: Cuadro de legislación comparada en materia de deducción por deudas incobrables

\begin{tabular}{|c|c|c|c|c|c|c|c|}
\hline CHILE & COLOMBIA & MEXICO & ARGENTINA & BOLIVIA & DOR & AY & \\
\hline \begin{tabular}{l}
\multicolumn{2}{l}{ DECRETO } \\
LEY N ${ }^{\circ} 824$ \\
LEY SOBRE \\
IMPUESTO A \\
LA RENTA
\end{tabular} & $\begin{array}{l}\text { ESTATUTO } \\
\text { TRIBUTARIO }\end{array}$ & $\begin{array}{lr}\text { LEY } & \text { DEL } \\
\text { IMPUESTO } & \text { SOBRE } \\
\text { LA RENTA } & \end{array}$ & $\begin{array}{l}\text { LEY } \mathbf{N}^{\circ} \quad 20628, \\
\text { IMPUESTO A } \\
\text { LAS } \\
\text { GANANCIAS }\end{array}$ & $\begin{array}{l}\text { TEXTO } \\
\text { ORDENADO } \\
\text { DE LA LEY } \\
\text { DE } \\
\text { REFORMA } \\
\text { TRIBUTARIA } \\
\quad \text { Ley } \\
843 \quad\end{array}$ & $\begin{array}{l}\text { CODIFICACIÓ } \\
\text { N 2004-026 } \\
\text { CODIFI } \\
\text { CACIÓN DE LA } \\
\text { LEY DE } \\
\text { RÉGIMEN } \\
\text { TRIBUTARIO } \\
\text { INTERNO }\end{array}$ & $\begin{array}{l}\text { NUEVO } \\
\text { SISTEMA } \\
\text { TRIBUTARIO } \\
\text { Ley } \mathbf{N}^{\circ} \mathbf{1 8 . 0 8 3}\end{array}$ & $\begin{array}{lrr}\text { LEY } \quad 27 / 2014 & \text { DEL } \\
\text { IMPUESTO } & \text { SOBRE } \\
\text { SOCIEDADES } & \end{array}$ \\
\hline $\begin{array}{l}{\text { Artículo } 31^{\circ}}^{(. .)} \\
\text {Especialmente } \\
\text { procederá la } \\
\text { deducción de los } \\
\text { siguientes } \\
\text { gastos, en cuanto } \\
\text { se relacionen con } \\
\text { el giro del } \\
\text { negocio: } \\
4^{\circ} \text {.- Los créditos } \\
\text { incobrables } \\
\text { castigados }\end{array}$ & $\begin{array}{lr}\text { Artículo } & \mathbf{1 4 5}^{\circ} . \\
\text { Deducción } & \text { de } \\
\text { deudas } & \text { de } \\
\text { dudoso o difícil } \\
\text { cobro. } \\
\text { Los contribuyentes } \\
\text { obligados a llevar } \\
\text { contabilidad, } \\
\text { podrán deducir las } \\
\text { cantidades } \\
\text { razonables que } \\
\text { fije el reglamento } \\
\text { como deterioro de }\end{array}$ & $\begin{array}{l}\text { Artículo } \mathbf{2 7}^{\circ} \text { Las } \\
\text { deducciones } \\
\text { autorizadas en este } \\
\text { Título deberán reunir } \\
\text { los siguientes } \\
\text { requisitos: } \\
(\ldots) \text { XV. Que en el } \\
\text { caso de pérdidas por } \\
\text { créditos incobrables, } \\
\text { éstas se consideren } \\
\text { realizadas en el mes en } \\
\text { el que se consuma el } \\
\text { plazo de prescripción, }\end{array}$ & $\begin{array}{l}\text { Artículo } 87^{\circ} \text { - De } \\
\text { las ganancias de la } \\
\text { tercera categoría y } \\
\text { con las } \\
\text { limitaciones de } \\
\text { esta ley también } \\
\text { se podrá deducir: } \\
\text { (...) } \\
\text { b) Los castigos y } \\
\text { previsiones contra } \\
\text { los malos créditos } \\
\text { en cantidades } \\
\text { justificables de }\end{array}$ & $\begin{array}{l}\text { Artículo } 47^{\circ} \\
(\ldots) \text { Para la } \\
\text { determinación } \\
\text { de la utilidad } \\
\text { neta imponible } \\
\text { se tomará como } \\
\text { base la utilidad } \\
\text { resultante de los } \\
\text { estados } \\
\text { financieros de } \\
\text { cada gestión } \\
\text { anual, } \\
\text { elaborados de }\end{array}$ & $\begin{array}{l}\text { Artículo } \mathbf{1 0}^{\circ} \text {.- } \\
\text { Deducciones } \\
\text { (...) En particular } \\
\text { se aplicarán las } \\
\text { siguientes } \\
\text { deducciones: } \\
(\ldots) \quad \text { Las } \\
\text { provisiones para } \\
\text { créditos } \\
\text { incobrables } \\
\begin{array}{l}\text { originados } \\
\text { operaciones del } \\
\text { giro ordinario del }\end{array}\end{array}$ & $\begin{array}{l}\text { Artículo } \mathbf{2 1}^{\mathbf{0}} \text {.- } \\
\text { Otras pérdidas } \\
\text { admitidas.- } \\
\mathrm{Se} \mathrm{admitirá,} \\
\text { asimismo, } \\
\text { deducir de la } \\
\text { renta bruta, en } \\
\text { cuanto } \\
\text { correspondan al } \\
\text { ejercicio } \\
\text { económico: } \\
\text { (...) } \\
\text { c) Los créditos }\end{array}$ & $\begin{array}{l}\text { Artículo } \mathbf{1 3}^{\circ} \text {. Correcciones } \\
\text { de valor: pérdida por } \\
\text { deterioro del valor de los } \\
\text { elementos patrimoniales. } \\
\text { 1. Serán deducibles las } \\
\text { pérdidas por deterioro de los } \\
\text { créditos derivadas de las } \\
\text { posibles insolvencias de los } \\
\text { deudores, cuando en el } \\
\text { momento del devengo del } \\
\text { Impuesto concurra alguna de } \\
\text { las siguientes circunstancias: } \\
\text { a) Que haya transcurrido el }\end{array}$ \\
\hline
\end{tabular}




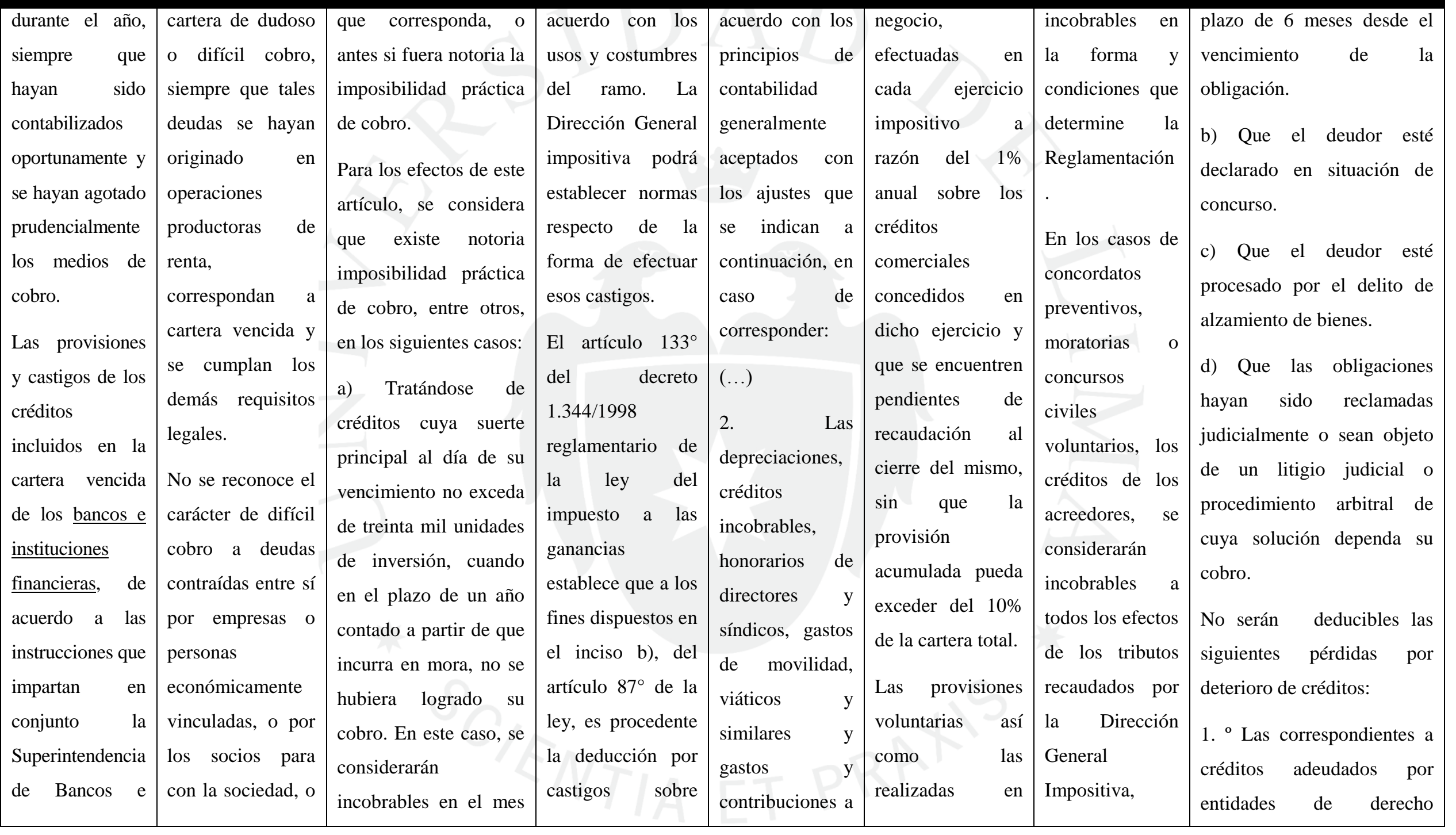




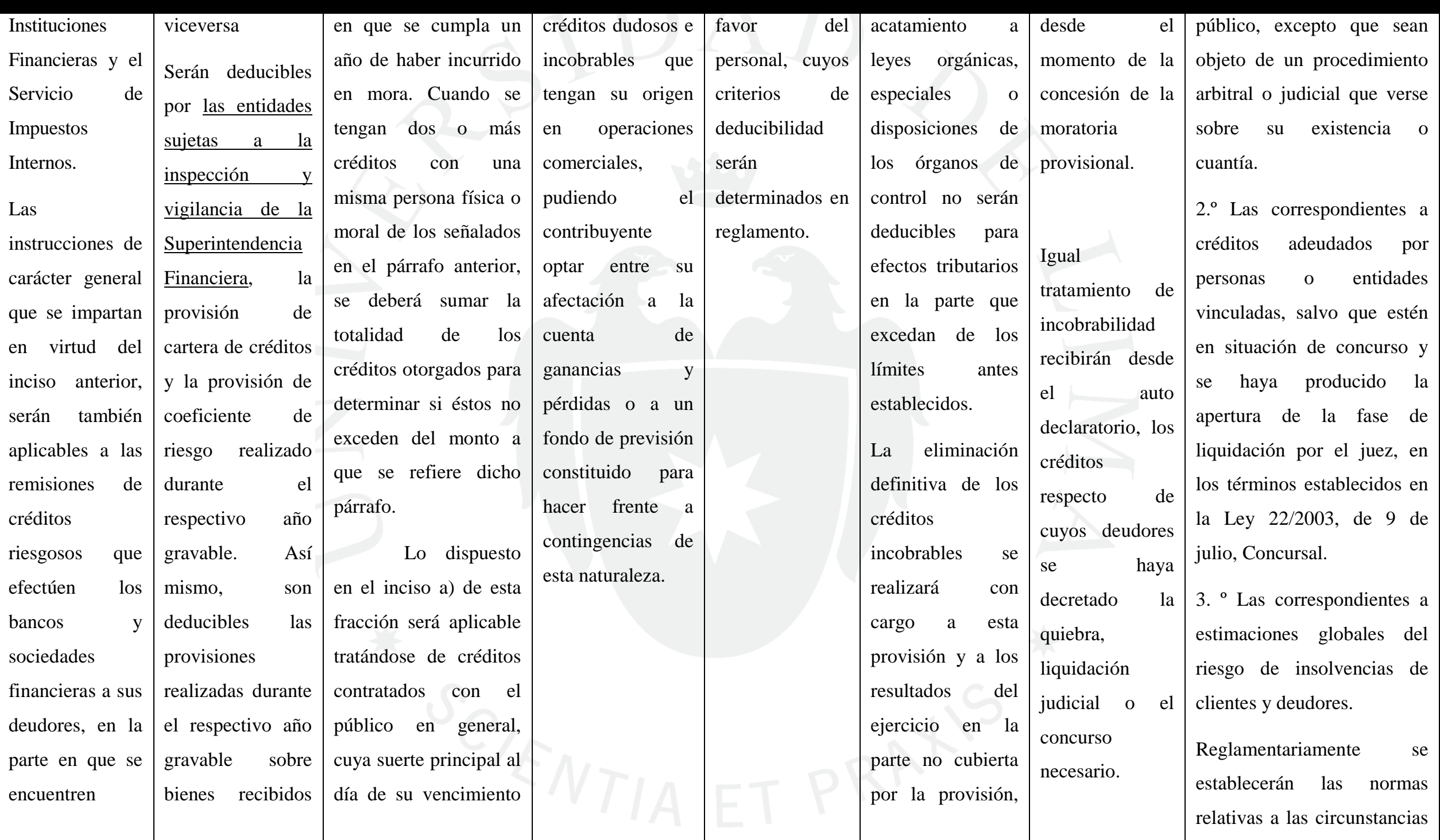




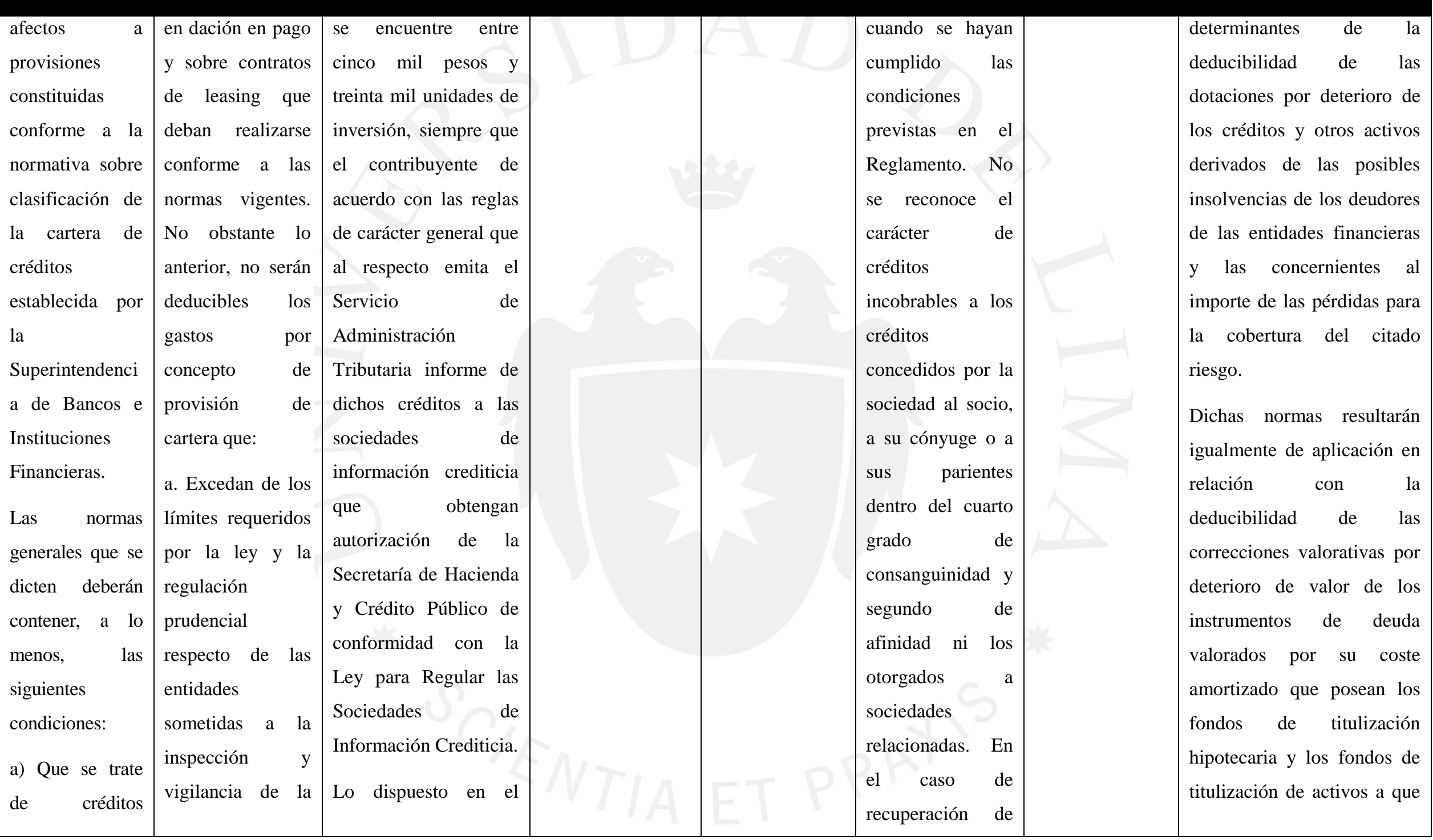




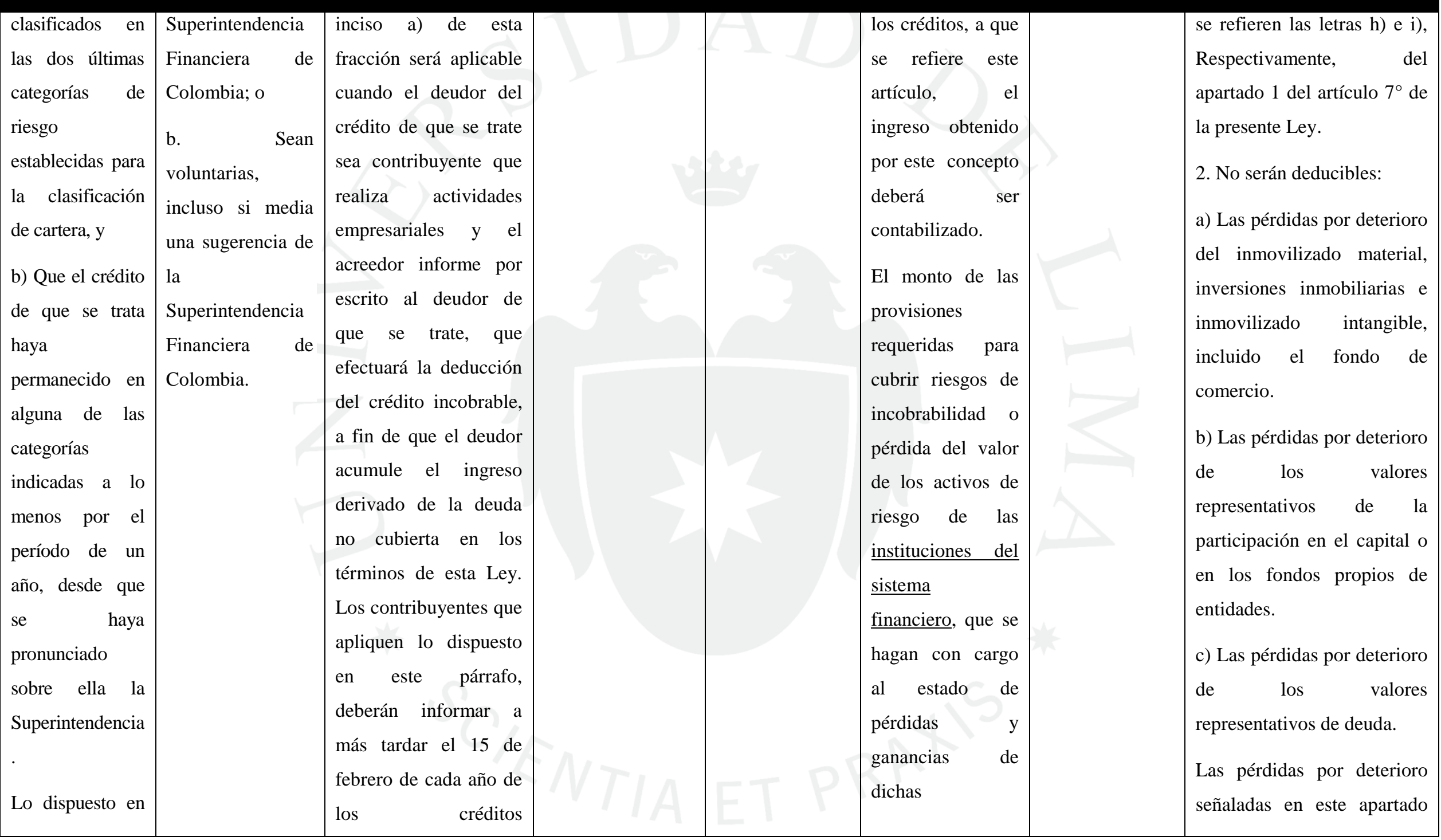




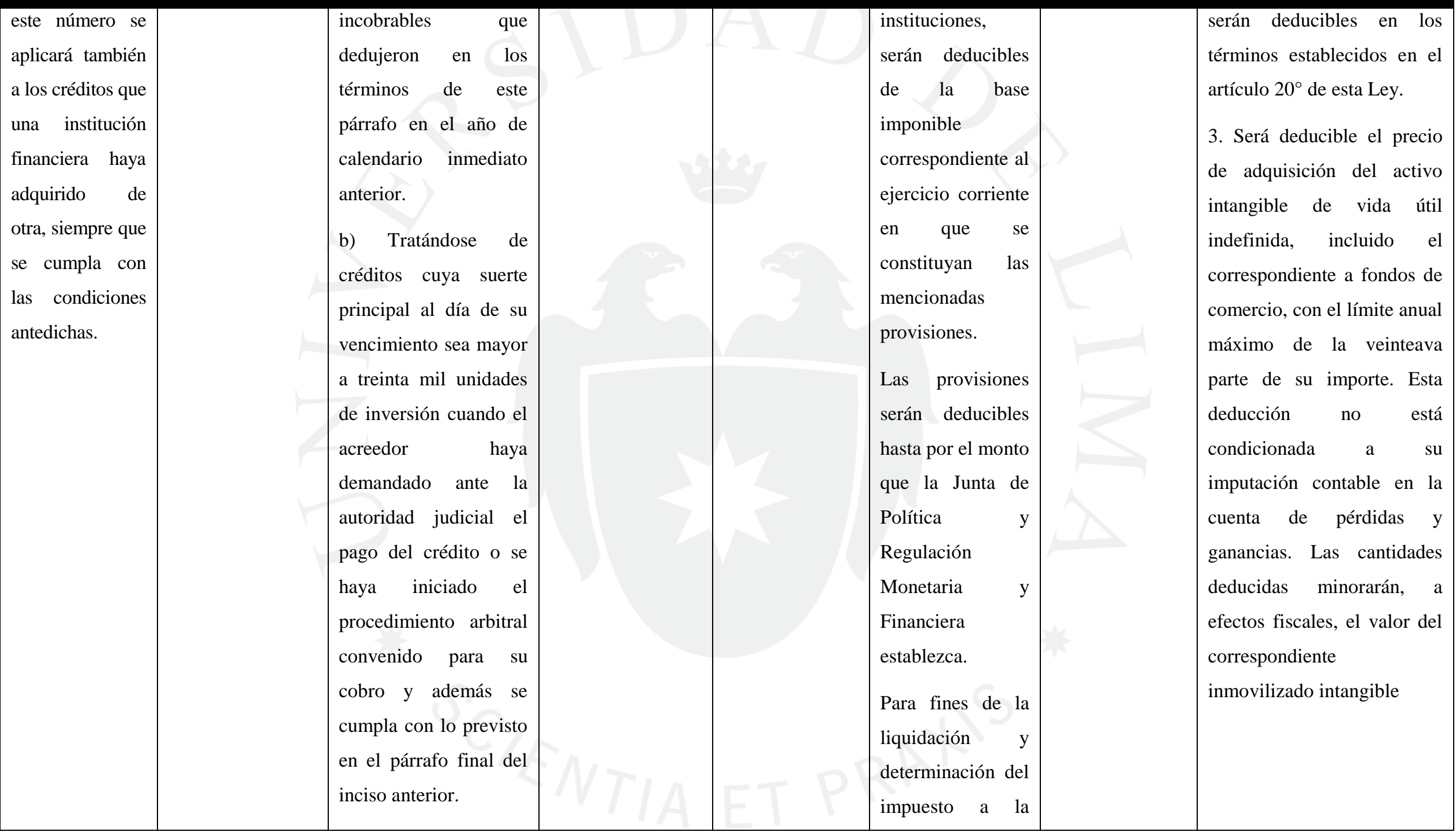




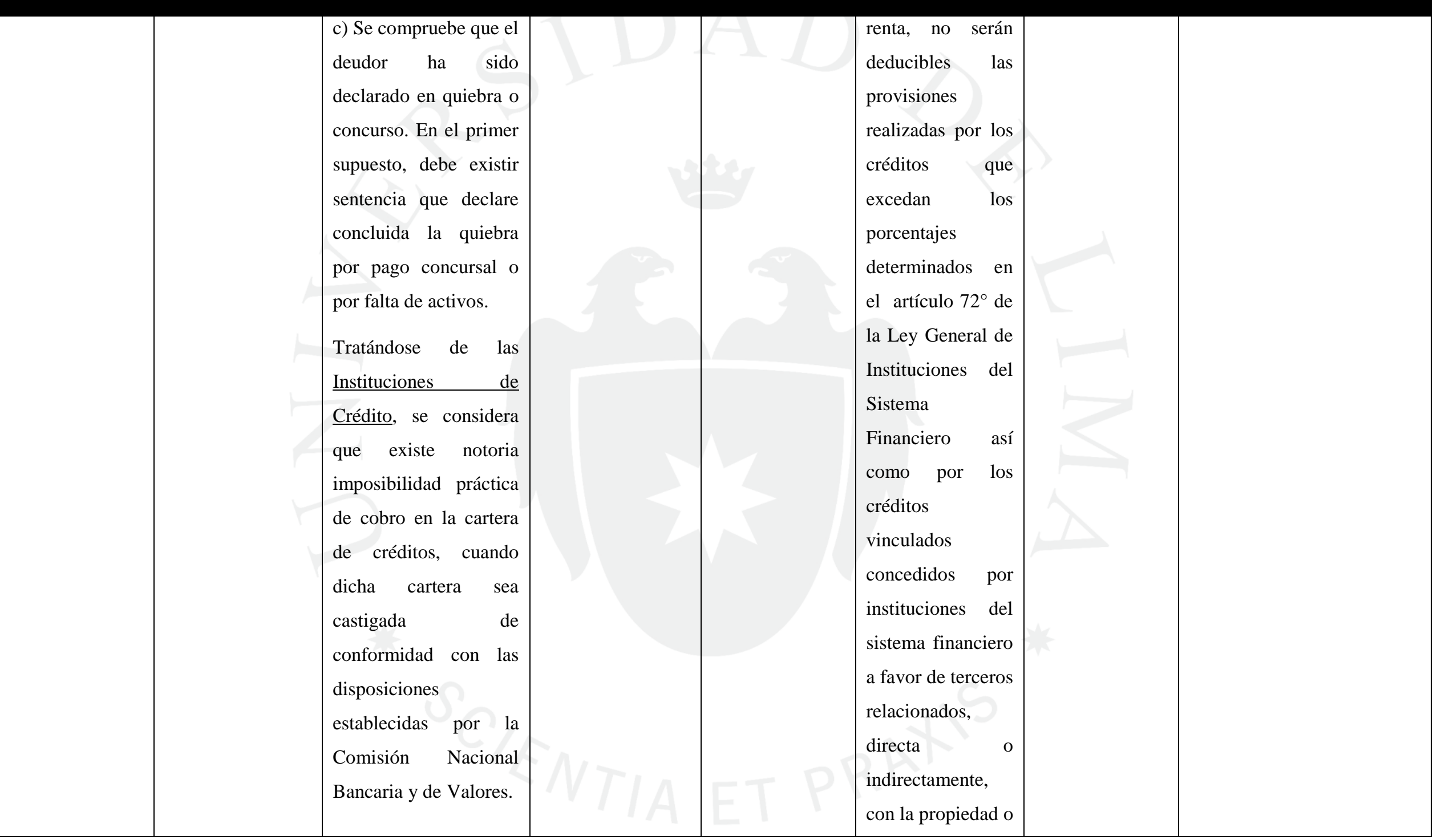




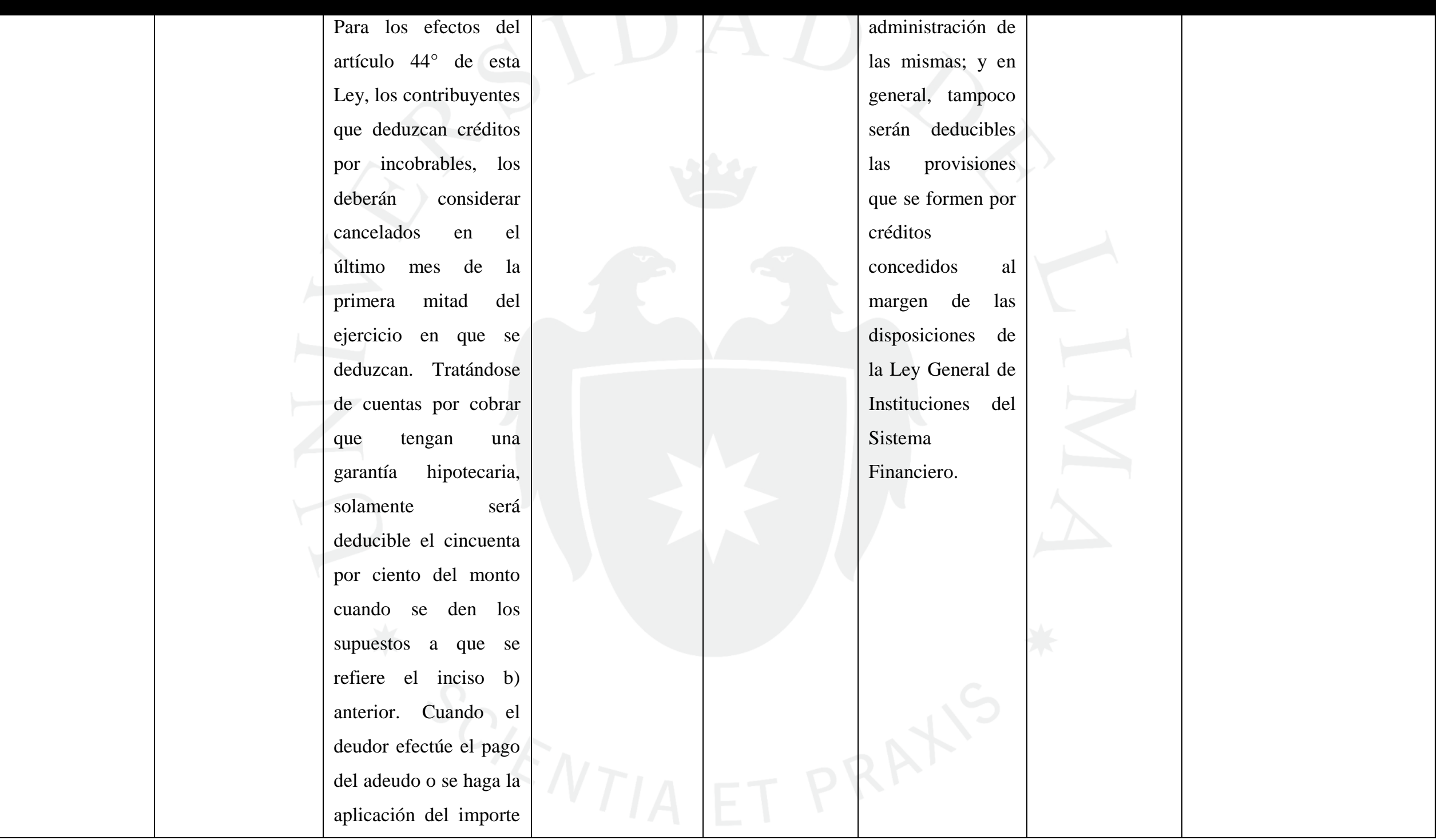


\begin{tabular}{|l|l|l|}
\hline & del remate a cubrir el
\end{tabular} adeudo, se hará la deducción del saldo de la cuenta por cobrar o en su caso la acumulación del importe recuperado.

Fuente: Elaboración propia 


\subsection{Posibles interpretaciones sobre el rol de los castigos}

En este punto analizaremos las posibles interpretaciones de la función de los castigos en el ámbito tributario tomando como referencia lo revisado en la evolución histórica, del desarrollo jurisprudencial, la doctrina y la legislación comparada:

\section{- Interpretación 1:}

Los castigos no tienen incidencia en la determinación del impuesto a la renta toda vez que la operación que afectó dicha determinación es la constitución de provisiones por deudas incobrables. En ese sentido tributariamente resulta irrelevante el cumplimiento de los requisitos del castigo. Esta afirmación, se sustenta en la dinámica contable que ya hemos visto en los capítulos anteriores, donde se ha explicado que es la provisión la que disminuye la renta neta imponible y el castigo implica la eliminación de la cuenta por cobrar devaluada.

Esta lectura encuentra su primer escollo en que la Ley del Impuesto a la Renta ha reconocido expresamente a los castigos como un hecho relevante para la determinación del impuesto. A mayor abundamiento el Reglamento del Impuesto a la Renta se ha preocupado en regular los requisitos del castigo. Asimismo la jurisprudencia del Tribunal Fiscal hasta la fecha se ha seguido pronunciando sobre los castigos y su relevancia en el impuesto a la renta (RTF $N^{\circ} 15081-1-2013$, entre otras).

\section{- Interpretación 2:}

Tanto las provisiones como los castigos son deducibles en la determinación del impuesto a la renta. En esta lectura existen hasta tres posibilidades de interpretación:

\section{○ Interpretación 2.1:}

Ambos conceptos son deducibles sobre el mismo incobrable y sobre el mismo importe, resultando de la lectura literal de la norma un posible beneficio autorizado por el fisco a modo de incentivo tributario.

Para calificar el tratamiento de un determinado concepto como un beneficio dentro del sistema tributario en principio se debe determinar el sistema base respecto del cual el concepto resultaría excepcional. Asimismo se debe determinar la finalidad del legislador para otorgar el referido beneficio, es decir 
la conducta que el legislador buscaría incentivar con su otorgamiento. En ese sentido, teniendo en cuenta que tanto los créditos provisionados como los créditos castigados son incobrables y en consecuencia ambos resultan parte del sistema base determinación del impuesto, no podría concluirse que estamos frente a un tratamiento excepcional; solo que como regla general una cuenta por cobrar primero deberá ser provisionada y luego castigada; con lo cual, la cuenta por cobrar castigada ya no debería ser deducible. No obstante, de no ser por la condición que introduce el Reglamento del Impuesto a la Renta, nada impediría que se efectúe un "castigo directo", sin provisión con lo cual cobraría sentido su deducción dentro del sistema base.

De lo expuesto, frente a una posible interpretación de la doble deducción de un incobrable, tampoco se desprende razonablemente ninguna conducta que el legislador haya querido incentivar. Por estos motivos se descarta que la deducción de provisiones y castigos se trate de un beneficio.

\section{○ Interpretación 2.2:}

Cuando la Ley regulaba la deducción de incobrables, se está refiriendo a provisiones y castigos directos -en los que no exista una previa provisión-, en ambos casos la disminución de la utilidad radicaba en el cargo a resultados de un gasto.

Como desarrollamos en el punto anterior tanto provisiones y castigos se refieren a deudas incobrables cuya deducción forma parte del sistema base del impuesto a la renta siendo que la diferencia entre ambos conceptos es cronológica, es decir, primero se provisiona y luego se castiga. Normalmente una deuda de cobranza dudosa pasa a ser provisionada dentro de la contabilidad y con ello afecta a los resultados del ejercicio. No obstante, salvo por el requisito del Reglamento del Impuesto a la Renta, tributariamente nada impediría que una cuenta por cobrar sea castigada directamente y con ello afecte también los resultados del ejercicio.

Esta lectura resulta coherente con lo regulado en la Ley del Impuesto a la Renta, con su evolución jurisprudencial, con la doctrina y con lo regulado en la legislación comparada; no obstante resulta difícil encontrar un ejemplo de una deuda que no requiera ser provisionada previo castigo. En efecto, agotar los 
medios judiciales para la recuperación de la deuda (requisito del castigo) resulta materialmente imposible que se haga en menos de un año con lo cual la deuda siempre deberá ser provisionada por lo menos por la causal de los doce meses, deducirse como provisión y posteriormente ser castigada.

De lo expuesto, el legislador frente a un mismo resultado, esto es, la deducción de incobrables, busco un tratamiento igualitario, sin embargo, qué duda cabe que para efectos de control tributario, el hecho de contar con una provisión previa al castigo siempre resultará más beneficioso que la desaparición de la cuenta por cobrar que origina el castigo directo.

\section{○ Interpretación 2.3:}

En principio deben deducirse las provisiones que cumplan los requisitos de la Ley del Impuesto a la Renta y su Reglamento. En caso de no cumplir con dichos requisitos, las provisiones no serán deducibles; sin embargo, sólo en dicha situación, serían deducibles los castigos de incobrables siempre que cumplan los requisitos legales, con lo cual no se pierde el derecho al gasto.

Este supuesto parte de la premisa que, contablemente, siempre debe realizarse una provisión de los créditos, pero al no cumplirse con los requisitos tributarios genera una adición en la determinación de la renta neta imponible, la misma que al pasar los filtros de los requisitos del castigo, extorna su efecto, originando la deducción del gasto original.

Nótese que de esta lectura a diferencia de la anterior, se condiciona la deducción del castigo a su previa provisión contable lo cual dejaría sin amparo a los castigos directos que como hemos visto han tenido un desarrollo jurisprudencial, doctrinario y que es aceptado a nivel de legislación comparada.

\section{- Interpretación 3:}

Como hemos visto, cuando la norma exige el cumplimiento de ciertos requisitos para el castigo, lo que podría estar buscando es que, a manera de doble filtro, no se pierda el control tributario de las cuentas que lo originan, de tal manera que si en un 
futuro se procediera con su recuperación se pueda establecer la correlación entre los conceptos que formaron su provisión $\left({ }^{40}\right)$.

Si bien, de una lectura literal del Reglamento de Renta, esta interpretación también es posible, sin embargo tiene muchos puntos débiles. En principio el requisito que mayor coherencia le da a esta interpretación, el de requerir la provisión previa al castigo, fue introducido por el legislador en un contexto en el que no se había reglamentado las provisiones como conceptos deducibles del impuesto (año 1978). Posteriormente, al regularse las provisiones como un concepto deducible no tiene mucho sentido exigir que el castigo también requiera su provisión previa, salvo la interpretación de que el castigo sea un doble filtro.

Otro punto débil, es que a nivel de legislación comparada ningún País requiere un doble filtro respecto de la deducción de incobrables, a pesar de tener requisitos muy similares a los que actualmente se requieren para la provisión en el caso peruano.

Finalmente debe tenerse en cuenta que un doble filtro para la deducción de incobrables, puede llevar al absurdo de reintegrar provisiones correctamente deducidas, incluso por el sólo hecho de no contar con la Constancia de Irrecuperabilidad dentro del plazo establecido, esto es, hasta la presentación de la declaración jurada anual, cuando el único hecho que debería originar este efecto es el cobro efectivo de la acreencia impaga; lo cual vulnera el principio de no confiscación y capacidad contributiva.

De lo revisado hasta este punto creemos que la interpretación más acorde con el contexto histórico y doctrinario es la que se refiere a la posibilidad de deducción de provisiones y castigos cuando estos castigos son directos (Interpretación 2.2).

No obstante, dado que actualmente siempre se podrán cumplir los requisitos de la provisión previa al castigo en la práctica resulta que el castigo directo, como un concepto deducible del impuesto, ha quedado desfasado siendo que debe ser la provisión y no el castigo lo que resulte deducible.

40 Supuesto que no puede conllevar a afirmar que se deba adicionar un gasto, ya que como se explicó, no existe tal provisión en dicho ejercicio, y menos aún que el activo financiero vuelva a tener contenido económico, pues es indiscutible que la disminución de su valor se dio al momento de la provisión y no en un momento posterior como es el castigo. 
En todo caso de lege ferenda convendría que el legislador establezca una regulación que prescinda de los términos contables de provisión y castigo a la hora de regular la deducción de incobrables limitándose a establecer las causales y los requisitos para su procedencia como concepto deducible del impuesto. En este contexto el contribuyente evaluaría si cumplió dichos requisitos y procedería a la deducción del incobrable independientemente si contablemente la deuda se encuentra en estado de provisionada o castigada.

Finalmente, toda vez que la deducción de incobrables está justificada en el mantenimiento de la fuente productora de renta resulta, justo que también se acepte como deducibles los castigos de deudas previamente provisionadas que en el momento de la provisión no cumplieron los requisitos tributarios pero que al momento del castigo se ha comprobado efectivamente su incobrabilidad por haberse agotado los medios judiciales para su recupero.

La deducción de estos castigos no puede estar condicionada a su previa provisión con efecto tributario. En todo caso, si se requiere contar con un control tributario, este debe ser coherente con lo establecido en la Ley que establece que el castigo es un concepto deducible per se. En todo caso, debe tenerse presente que el control tributario tiene que ver con un tema de prueba que en el caso de los créditos castigados lo cumple la sentencia judicial donde se determina su irrecuperabilidad o, en el caso de los bancos, la constancia de irrecuperabilidad emitida por la SBS, si el Fisco así lo considera conveniente. 


\section{CAPÍTULO III: TRANSFERENCIA DE LA CARTERA CASTIGADA}

\subsection{Créditos en el derecho civil y en la doctrina}

Económicamente los créditos o cuentas por cobrar pueden ser objeto de comercio. Así por ejemplo si A (deudor) le debe a B (acreedor) una determinada cantidad de dinero como consecuencia de un préstamo, una indemnización u otro título, B podría transferir ese crédito a $\mathrm{C}$ (tercero) y así lograr que $\mathrm{C}$ sea quien finalmente cobre esa cantidad de dinero. La transferencia del crédito de $\mathrm{B}$ a $\mathrm{C}$ puede originarse por diferentes motivos: la necesidad de efectivo que tiene $\mathrm{B}$, un acto de liberalidad (donación) de $\mathrm{B}$ a $\mathrm{C}$, entre otros. Jurídicamente existen diversas formas en las que se puede lograr ese efecto, es decir que sea finalmente $\mathrm{C}$ quien cobre la acreencia, ya sea mediante una cesión de créditos, un contrato de descuento, un contrato de factoring, entre otros.

A decir de Castillo Freyre (2008):

La cesión de créditos no es sino una especie dentro un género más amplio constituido por la cesión de derechos. Explica este autor que los derechos no solo son los créditos sino toda clase de derechos patrimoniales transferibles. En ese sentido la transferencia de estos derechos se hacen mediante un contrato de cesión de derechos, siempre que no tengan por ley un mecanismo de transmisión distinto. Agrega que mediante la cesión se transmiten los derechos que han sido adquiridos o transferidos en virtud de título distinto, ya sea contractual, por ejemplo una compraventa; o extracontractual, por ejemplo la herencia o cuando una disposición legal así lo ordena. (p. 1)

De otro lado Barchi Velaochaga (2004) señala que

La titularidad de un crédito puede ser objeto de transferencia, como lo puede ser cualquier situación jurídica, salvo que las partes, la naturaleza de la obligación o la ley lo impidan. En otras palabras, el crédito, como la propiedad, es un bien y, por tanto, puede ser objeto de transferencia”. (p. 353)

Añade el citado autor, que la cesión de créditos a título oneroso no es otra cosa que una hipótesis calificada de compraventa, es decir, aquel contrato que vale como "tipo" de negocio traslativo oneroso. En consecuencia, el régimen de la cesión onerosa debe 
regirse, salvo excepciones expresamente señaladas, por las reglas de la compraventa. (p. 359)

De lo anterior se tiene que jurídicamente en el derecho civil se presentan dos teorías sobre la cesión de créditos: una que lo identifica como una especie del género cesión de derechos mediante el cual se transmiten derechos que nacen de otras relaciones jurídicas (contratos de préstamo, responsabilidad civil, entre otros) y otra que lo califica como una compraventa en si misma que recae sobre créditos.

En el aspecto civil, el artículo $1206^{\circ}$ del Código Civil establece que la cesión es el acto de disposición en virtud del cual el cedente trasmite al cesionario el derecho a exigir la prestación a cargo de su deudor, que se ha obligado a transferir por un título distinto. Añade, que la cesión puede hacerse aun sin el asentimiento del deudor.

De la lectura de esta norma se puede inferir que se está regulando solamente la cesión del derecho a exigir el cumplimiento de créditos y no así la cesión de derechos en general.

Ahora bien, en toda operación de crédito intervienen un acreedor y un deudor frente a cuyo débito se manifiesta el correspondiente crédito, es decir, el derecho del acreedor a una contraprestación futura. El crédito mercantil propiamente dicho, necesariamente debe provenir de una precedente operación de crédito y tener el respaldo de una actividad productiva y por ende de una riqueza creada; según esto, una vez que el crédito propiamente dicho adquiere tal naturaleza cobra vida autónoma, pudiendo inclusive constituirse en objeto de nuevas operaciones de crédito, o sea que puede ser transferido sucesivamente ( Rivas Gomez, 1988, p. 122).

De otro lado los contratos de descuento y de factoring pueden ser definidos como subespecies de la cesión de créditos. A decir de la doctrina el contrato de descuento consiste en la entrega de una suma de dinero por parte del banco (descontante) a su cliente (descontado) a cambio que este último le transfiera un crédito no vencido a cargo de un tercero. El monto de la entrega realizada por el banco está determinado por el valor del crédito transferido menos el interés equivalente al plazo pendiente entre la fecha del descuento y la del vencimiento del título. Agrega la doctrina que la transferencia del crédito por parte del descontado no es liberatoria de su obligación de lo que resulta que la responsabilidad final de pago recae de manera solidaria en el descontado. 
Los contratos de factoring se definen como aquellos en los cuales una persona (factor) adquiere de otra (denominada cliente) derechos de crédito que tiene a su favor y que se encuentran sustentados en documento de contenido crediticio, prestando en algunos casos servicios adicionales. A diferencia del descuento, el factoring otorga al cedente la posibilidad de transferir una cuenta por cobrar, sin asumir responsabilidad final sobre el pago de la misma.

Si bien es cierto civilmente las transferencias de créditos pueden efectuarse bajo distintas formas (cesión de créditos, factoring, descuento, entre otros) lo cierto es que en otras ramos del derecho se puede prescindir de dichas formas para darle un tratamiento acorde con el fenómeno económico que ocurre, cuestión que analizaremos más adelante.

\subsection{Regulación pertinente de la Superintendencia de Banca y Seguros}

El numeral 26 del artículo $221^{\circ}$ de la Ley General del Sistema Financiero señala que las empresas del sistema financiero pueden celebrar contratos de compra o de venta de cartera. Siendo así en el marco de esta normativa, mediante Resolución SBS No 1308 2013, se aprobó el Reglamento de transferencia y adquisición de cartera crediticia, con lo cual, las empresas que hayan sido autorizadas por la SBS a realizar las operaciones de compra o venta de cartera deberán observar lo dispuesto en el citado Reglamento, en lo que resulte pertinente.

En dicha Resolución se señala que la cartera crediticia, es aquella conformada por los créditos directos, créditos indirectos, créditos castigados y otras operaciones de naturaleza similar; o por los derechos vinculados a ellos, incluyendo, pero no limitándose, a los flujos de caja.

A su vez, el artículo $4^{\circ}$ establece que las empresas podrán transferir su cartera crediticia mediante venta, cesión de derechos, cesión de posición contractual u otras modalidades contractuales. Las transferencias a personas vinculadas deberán efectuarse al valor razonable, determinado de acuerdo a un estudio técnico donde se indique la metodología utilizada para determinar dicho valor. Este estudio técnico deberá estar a disposición de la SBS.

Por su parte, el artículo $7^{\circ}$ señala que las empresas deben solicitar autorización previa a la SBS, por las operaciones de transferencia de cartera crediticia al contado con 
pacto de recompra u opción de compra debidamente autorizadas por la SBS, así como por otras transferencias que requieran autorización previa de la misma, las empresas presentarán una solicitud adjuntando, por lo menos, la información y documentación que se señala en el Anexo A del citado Reglamento. Estas transferencias sólo surtirán efecto una vez que se cuente con autorización de la SBS.

Para el caso de transferencias a personas vinculadas, las empresas deben solicitar autorización previa a la SBS cuando la cartera crediticia sea transferida a personas vinculadas a la empresa transferente, independientemente de si la operación se realiza al contado o de manera financiada, excepto en los casos de transferencias realizadas al contado que se detallan a continuación:

a) Se trate de transferencias de cartera crediticia castigada; $o$,

b) Se trate de transferencias de cartera crediticia no castigada, siempre y cuando los créditos se encuentren clasificados como pérdida y provisionados cien por ciento $(100 \%)$.

Para el caso de transferencias a personas no vinculadas, las empresas deben solicitar autorización previa a la SBS cuando la cartera crediticia sea transferida a personas no vinculadas a la empresa transferente, excepto en cualquiera de los siguientes casos:

a) Se trate de transferencias de cartera crediticia castigada (contado o financiada);

b) Se trate de transferencias de cartera crediticia no castigada, siempre y cuando los créditos se encuentren clasificados como pérdida y provisionados cien por ciento $(100 \%)$ (contado o financiada); o,

c) Se trate de transferencias al contado mediante pagos dinerarios, siempre y cuando se haya efectuado al menos al valor en libros neto de provisiones específicas requeridas.

Nótese, de las normas glosadas que existe una regulación expresa por parte de la SBS para que las empresas del sistema financiero, que decidan transferir su cartera castigada a un tercero vinculado o no, lo haga dentro del referido marco normativo. No obstante a lo anterior, como hemos visto las normas de la SBS y las normas tributarias tienen objetivos distintos; por poner un ejemplo, para efectos de la SBS el transferente deberá comunicar a ésta las transferencias; sin embargo, su incumplimiento no generaría ninguna contingencia tributaria. 


\subsubsection{De los aspectos contables e información complementaria}

El registro contable de las operaciones de transferencia y adquisición de cartera crediticia, se realizará teniendo en cuenta las disposiciones establecidas en el Manual de Contabilidad.

Al respecto, de acuerdo a las disposiciones contenidas en el Manual de Contabilidad para las empresas del sistema financiero $\left({ }^{41}\right)$ una entidad contabilizará la transferencia de cartera de créditos, como una baja de dicha cartera, conforme con los lineamientos establecidos en las Normas Internacionales de Información Financiera, siguiendo adicionalmente las siguientes pautas:

- La empresa transferente deberá registrar la disminución de créditos directos, créditos indirectos y cuentas de orden (en caso de cartera castigada) al momento de la transferencia de la cartera crediticia.

- Las ganancias originadas por la transferencia de la cartera crediticia se reconocerán como ingreso. En los casos de transferencias mediante permuta o financiadas, dichas ganancias se reconocerán como un ingreso diferido, el cual se irá devengando en función a los ingresos dinerarios que se obtengan por la realización de los bienes recibidos en permuta, o proporcionalmente a la percepción del pago de la adquirente de la cartera crediticia transferida, respectivamente.

- Las pérdidas originadas por la transferencia de cartera crediticia se reconocerán al momento de la transferencia.

Nótese que, para efectos contables, la eliminación efectiva de la cuenta castigada se da con la transferencia de créditos siendo esta operación la que determina su disminución o eliminación dentro de la contabilidad del transferente.

41 http://www.sbs.gob.pe/principal/categoria/bancos-financieras-y-otros/117/c-117. 


\subsection{Regulación tributaria de las transferencias de créditos}

Como vimos anteriormente respecto de las transferencias de crédito civilmente existen dos teorías en cuanto a su naturaleza: (i) ya sea como una especie del género cesión de derechos o (ii) como una compraventa especial o calificada.

Tributariamente, lo que interesa en estas operaciones es gravar la manifestación de riqueza creada a través de las mismas y que se expresa ya sea en la forma de renta, consumo o patrimonio. Para dicho objetivo el legislador, dentro de la autonomía reconocida al derecho tributario, puede optar por considerar las operaciones como una operación de servicios o como una enajenación de bienes de conformidad con su esencia económica. Nótese que en ambos casos se gravará la riqueza creada pero dependiendo de si se considera como un servicio o como una enajenación, las implicancias tributarias en cuanto a reglas de fuente, nacimiento de la obligación tributaria y demás, serán diferentes.

En línea con lo anterior, por ejemplo para efectos del IGV el artículo $75^{\circ}$ del TUO de la Ley del IGV e ISC $\left({ }^{42}\right)$, incorporado mediante Ley $N^{\circ} 27039$ (1998), dispone que las transferencias de créditos en las que el adquirente asume el riesgo crediticio del deudor no constituye venta de bienes ni prestación de servicios siendo una operación inafecta del impuesto. Asimismo, se señala que en las transferencias de créditos en las que el adquirente no asume el riesgo crediticio del deudor se considera que existe la prestación de un servicio de financiamiento que solo se gravará con el impuesto cuando dicho adquirente devuelva los créditos al transferente o este los recomprara. De lo expuesto, las normas del IGV prescinden de la calificación civil otorgada a las trasferencias de crédito (cesión de derechos, factoring, etc) y en vez de ello regula sus implicancias tributarias.

Por otro lado, para efectos del impuesto a la renta, la Segunda Disposición Complementaria Final del Decreto Supremo $N^{\circ}$ 219-2007-EF, establece que las transferencias de crédito realizadas a través de operaciones de factoring, descuento $\mathrm{u}$ otras operaciones reguladas por el Código Civil, por las cuales el factor, descontante o adquirente adquiere a título oneroso, de una persona, empresa o entidad, (cliente o transferente), instrumentos de contenido crediticio, tienen las siguientes implicancias:

42 Aprobado por Decreto Supremo Nº55-99-EF, publicada el 15 de abril de 1999. 
2. En las transferencias de créditos en las que el adquirente asume el riesgo crediticio del deudor:

2.1 Para el factor o adquirente del crédito: La diferencia entre el valor nominal del crédito y el valor de transferencia constituye un ingreso por servicios, gravable con el impuesto a la renta.

2.2 Para el cliente o transferente del crédito: La transferencia del crédito le genera un gasto deducible, determinado por la diferencia entre el valor nominal del crédito y el valor de transferencia.

3. En las transferencias de créditos en las que el adquirente no asume el riesgo crediticio del deudor:

3.1 Para el descontante o adquirente del crédito: La diferencia entre el valor nominal del crédito y el valor de transferencia constituirá interés por el servicio de financiamiento.

3.2 Para el cliente o transferente del crédito: La diferencia entre el valor nominal del crédito y el valor de transferencia constituirá gasto deducible por concepto de intereses por el servicio de financiamiento.

Agrega la norma, que para efectos del impuesto a la renta las transferencias de créditos se sustentarán con el contrato correspondiente $\left({ }^{43}\right)\left({ }^{44}\right)$.

43 Si bien la norma fue publicado el 31.12.2007 vigente a partir del 1.1.2008, cabe indicar que en la Exposición de Motivos del Reglamento en mención se señala que "Actualmente, por vía de interpretación puede llegarse a la conclusión de que corresponde aplicar el tratamiento señalado en la propuesta, sin embargo, en la medida que es fruto de la interpretación no existe la seguridad jurídica que los contribuyentes desean como respaldo de sus operaciones".

44 Al respecto debe tenerse en cuenta que mediante primera disposición complementaria modificatoria de la Ley $\mathrm{N}^{\circ} 30532$, Ley que promueve el desarrollo del Mercado de Capitales, se incorporó un inciso g) al artículo 10 del TUO de la LIR el mismo que dispuso que son rentas de fuente peruana:

"Las obtenidas por las transferencias de créditos realizadas a través de operaciones de factoring u otras operaciones reguladas por el Código Civil en las que el factor o adquirente del crédito asume el riesgo crediticio del deudor, cuando el cliente o transferente del crédito sea un sujeto domiciliado en el país, de no ser así, cuando el deudor cedido sea domiciliado en el país.

Se incluye dentro del concepto de deudor cedido o cliente o transferente del crédito a la Sociedad Administradora de un Fondo de Inversión o Fondo Mutuo de Inversión en Valores, a la Sociedad Titulizadora de un Patrimonio Fideicometido y al fiduciario del Fideicomiso Bancario.

En el caso de que el deudor cedido sea una persona natural, sucesión indivisa o sociedad conyugal que optó por tributar como tal, se presume que tiene la condición de domiciliado si está inscrito en el Registro Único del Contribuyente o comunica dicha situación al factor o adquirente del crédito, salvo prueba en contrario"

Según la exposición de motivos del proyecto de ley la intención del legislador habría sido señalar un criterio de vinculación específico para las operaciones de transferencia de créditos en las que el 
En opinión de R. Ramírez-Gastón y A. Ramírez-Gastón (2008):

La norma reglamentaria pretende modificar la naturaleza jurídica de una operación de cesión de derechos de crédito, pues para ellos, en las cesiones de crédito donde se transfiere el riesgo crediticio del deudor lo que se produce es una enajenación del derecho de crédito, un acto de disposición, es decir, la transferencia de un crédito de una persona a otra. En consecuencia, a decir de los autores, no se entiende como en virtud de una simple norma reglamentaria se puede establecer que la cesión de un derecho de crédito, que es equivalente a un contrato de compraventa de un derecho de crédito, también pueda calificar como un contrato de locación de servicios (p. 212).

Lo cierto es que, como ya habíamos anticipado, dentro de la autonomía del derecho tributario, la legislación tributaria puede despojar una operación de sus formas civiles para reconocer su esencia económica y de conformidad con ella darle un tratamiento adecuado para efectos tributarios. En el caso de transferencias de crédito en las que el adquirente asume el riesgo crediticio del deudor, lo criticable de la regulación en el caso del impuesto a la renta, además del rango de norma utilizado $\left({ }^{45}\right)$, es que económicamente no se explica cuál es el servicio que estaría prestando el adquirente de los créditos al transferente de los mismos.

A mayor abundamiento en las RTF No 04964-4-2002 y 01719-1-2003 se llega a la conclusión que la cesión de créditos en la que el adquirente asume el riesgo crediticio del deudor no constituye una prestación de servicios. Si bien las Resoluciones se refieren al Impuesto General a las Ventas el análisis que efectúa el Tribunal Fiscal es aplicable a las transferencias de crédito sin responsabilidad en general. Lo mismo ocurre con el Informe $\mathrm{N}^{\circ}$ 082-2005-SUNAT/2B0000 en el que para efectos distintos al IGV la SUNAT concluye que en este tipo de transferencias existe obligación de emitir

adquirente asume el riesgo crediticio del deudor toda vez que con anterioridad habría estado comprendida en el criterio genérico comprendido en el literal e) del artículo 9 del TUO de la LIR. No obstante, toda vez que el tema objeto del presente trabajo versa sobre lo que ocurre en cabeza del transferente de los créditos castigados más que del análisis que corresponde al adquirente de los referidos créditos, la incorporación dispuesta mediante primera disposición complementaria modificatoria de la Ley $\mathrm{N}^{\circ} 30532$ no será objeto de mayor análisis.

45 Si se pretende otorgar una determinada naturaleza a una operación esta debe hacerse respetando el principio de legalidad. Recordemos que en el caso del IGV el tratamiento de las transferencias de crédito fue dispuesto por Ley y no por Reglamento. 
comprobante de pago por la causal de transferencia de bienes (y no la de prestación de servicios) $\left({ }^{46}\right)$.

Derivado de lo anterior también resulta criticable que el reglamentador haya considerado que la diferencia entre el valor nominal del crédito y el valor de transferencia constituye un gasto deducible para el transferente porque si bien dicha diferencia constituye un concepto deducible en principio su naturaleza no corresponde a un gasto toda vez que en este tipo de operaciones el valor nominal del crédito constituye un costo y cualquier diferencia negativa respecto de su valor de transferencia debería ser considerado como una pérdida.

En todo caso la transferencia de créditos donde se transfiere el riesgo crediticio del deudor, que es la que estamos analizando, es una especie de enajenación a que se refiere el artículo $5^{\circ}$ de la LIR y en consecuencia resulta ser una operación gravada con el impuesto a la renta, siendo que a efecto de determinar la renta bruta corresponde determinar la diferencia entre el ingreso y el costo computable del bien transferido.

\subsection{Determinación del valor nominal en la transferencia de crédito}

La determinación del impuesto parte del concepto de "ingresos", el cual es entendido como la totalidad de los ingresos afectos al impuesto a la renta precisando que "cuando tales ingresos provengan de la enajenación de bienes, la renta bruta será la diferencia existente entre el ingreso total proveniente de dichas operaciones y el costo computable de los bienes enajenados" (Artículo 20 de la LIR).

Como hemos referido para los efectos de la LIR, "se entiende por enajenación la venta, permuta, cesión definitiva, expropiación, aporte a sociedades y, en general, todo acto de disposición por el que se transmita el dominio a título oneroso" (Artículo 5 de la LIR).

Ahora bien, los derechos de crédito califican como bienes de conformidad con el artículo $886^{\circ}$ del Código Civil $\left({ }^{47}\right)$, por otro lado, el artículo $923^{\circ}$ del citado Código

${ }^{46}$ Cabe precisar que de acuerdo con el artículo $1^{\circ}$ del Reglamento de Comprobantes de Pago, el comprobante de pago es un documento que acredita la transferencia de bienes, la entrega en uso, o la prestación de servicios.

47 El numeral 5 del Artículo $886^{\circ}$ del Código Civil, señala que son bienes muebles, los títulos valores de cualquier clase o los instrumentos donde conste la adquisición de créditos o de derechos personales. 
señala que la propiedad es el poder jurídico que permite usar, disfrutar, disponer y reivindicar un bien.

Con relación al "costo computable", el artículo $20^{\circ}$ de la LIR dispone que la renta bruta está constituida por el conjunto de ingresos afectos al impuesto que se obtengan en el ejercicio gravable y que en la enajenación de bienes, la renta bruta estará dada por la diferencia existente entre el ingreso neto total proveniente de dichas operaciones y el costo computable de los bienes enajenados, siendo el costo computable el costo de adquisición, producción o construcción, o en su caso, el valor de ingreso al patrimonio o valor en el último inventario determinado conforme a Ley, ajustados de acuerdo a las normas de ajustes por inflación con incidencia tributaria, según corresponda.

De la norma glosada, se puede inferir que el costo computable puede referirse a un "costo de adquisición", entendido como la contraprestación pagada por un bien adquirido, a un "costo de producción" entendido como el monto incurrido en la producción o construcción del bien, o un "'valor de ingreso al patrimonio" entendido como el valor de mercado de los bienes obtenidos, siendo que tales disposiciones se orientan a permitir que el enajenante de un bien pueda reconocer como costo del mismo lo que hubiese desembolsado en adquirirlo, crearlo u obtenerlo.

De lo expuesto, se entiende que la cesión de créditos castigados por las empresas del sistema financiero es un concepto que se encuentra dentro del ámbito de aplicación del impuesto a la renta $\left({ }^{48}\right)$; y que en las transferencias de crédito, la renta gravada o pérdida deducible, se obtiene de la diferencia entre el ingreso originado por el valor de transferencia y su costo computable.

Así pues, siendo que al no tener una referencia expresa a cuál sería el costo computable dentro del marco del artículo $20^{\circ}$ de la LIR, el reglamentador ha señalado que éste correspondería al valor nominal; sin embargo, no ha definido que se entiende por dicho concepto por lo que podría generar incertidumbre.

Ahora bien, cabe advertir que como se concluyó en los capítulos anteriores, al tratarse de bienes íntegramente provisionados, el costo computable de los créditos correspondiente a colocaciones y cuentas por cobrar se extinguió al momento de la provisión, siendo su valor nominal equivalente a cero en dicha oportunidad.

${ }^{48}$ Bajo la teoría de Flujo de Riqueza, desarrollado en el capítulo I del presente trabajo. 
En esa línea, bajo el supuesto que el contribuyente dedujo íntegramente el valor nominal de los créditos (colocaciones y/o cuentas por cobrar) cuando registró la provisión de incobrabilidad no resultaría razonable que nuevamente se reconozca el valor nominal del activo financiero al momento en que realice su transferencia, puesto que ello implicaría deducir doblemente el mismo concepto.

Por lo expuesto, las implicancias tributarias de la transferencia de créditos cuando éstos se encuentren en estado de "castigo", serían los siguientes:

Figura 3.1: Implicancias de la Transferencia de Créditos

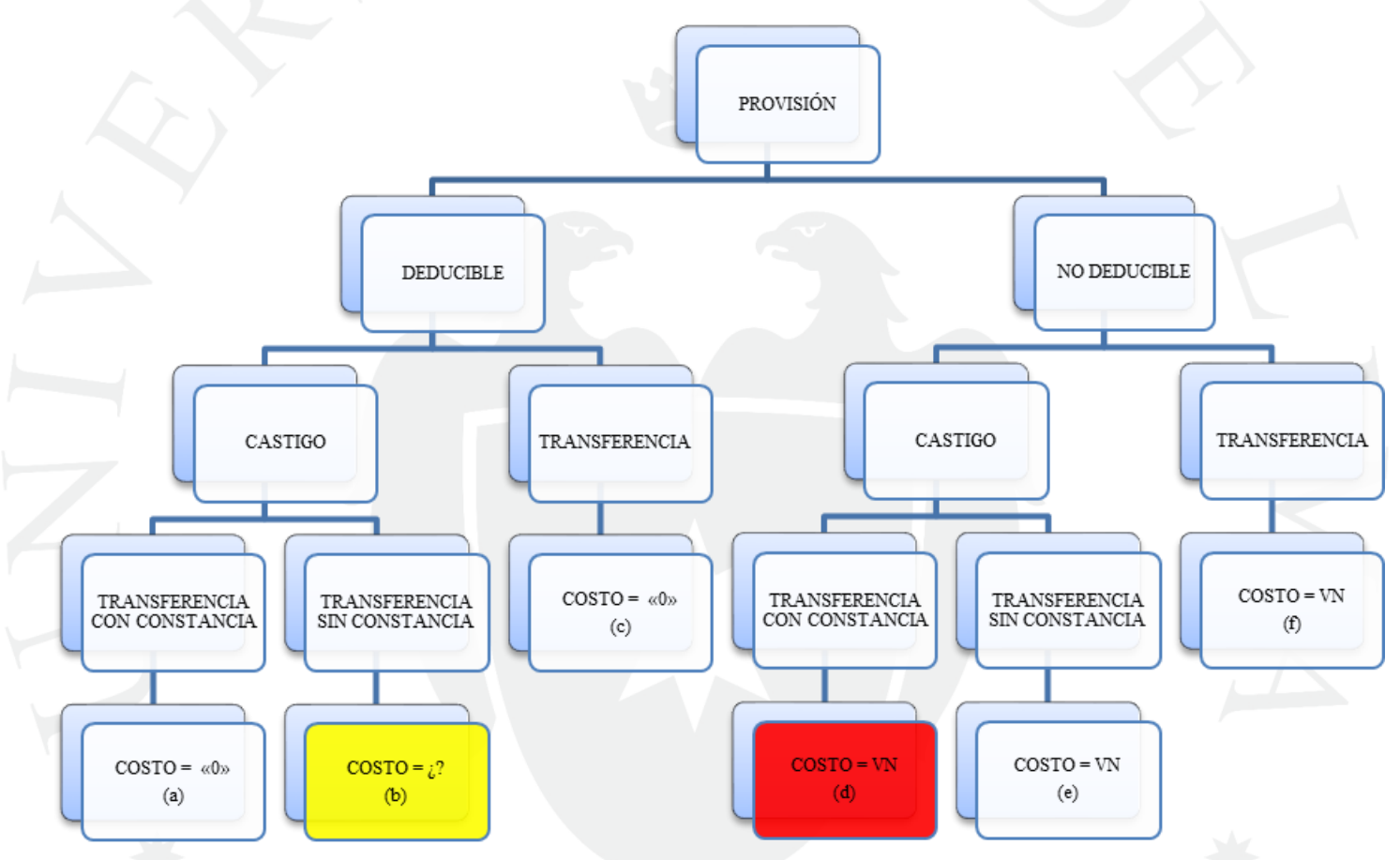

Fuente: Elaboración propia

\section{Supuestos:}

a) Si se cumplieron los requisitos tributarios para la deducción de la provisión de cobranza dudosa, cumpliéndose también los requisitos del castigo, qué duda cabe que el costo tributario del crédito transferido sería igual a cero.

b) En el caso que se cumplan con los requisitos tributarios de la provisión, pero no los requisitos del castigo, nace la discusión si el costo tributario del crédito transferido sería igual a cero o a su valor nominal. Este es el tema que motivo esta investigación cuyas conclusiones daremos más adelante. 
c) En el supuesto que, se cumplieron los requisitos tributarios para la deducción de la provisión de cobranza dudosa y se efectúa su transferencia en lugar del castigo, el costo tributario del crédito transferido sería igual a cero.

d) Si no se cumplieron los requisitos tributarios de la provisión, pero se cumplió con obtener la constancia de irrecuperabilidad; el costo tributario del crédito en su posterior transferencia, sería el valor nominal que le corresponde al mismo. No obstante a lo anterior, en una teoría de la causalidad que le asiste a los créditos incobrables qué duda cabe que el gasto debería deducirse al momento de efectuar el castigo sin necesidad de su venta, pero nunca el doble beneficio, esto es, si el gasto se dedujera en el castigo, en la transferencia el valor nominal del crédito sería igual a cero.

e) Si no se cumplieron los requisitos tributarios de la provisión ni tampoco los requisitos del castigo, entonces el costo tributario del crédito en su posterior transferencia es el valor nominal que le corresponde al mismo. Nos preguntamos en este escenario cuál sería la contingencia tributaria de no contar con la Constancia de Irrecuperabilidad, queda claro que la respuesta sería ninguna.

f) Finalmente, en el supuesto que no se cumplieron los requisitos tributarios para la deducción de la provisión de cobranza dudosa, y se efectúo la transferencia del crédito previo a su castigo, el costo tributario del crédito en su posterior transferencia es el valor nominal que le corresponde al mismo.

Ahora bien, en el supuesto planteado en el literal b), esto es, que se cumplan con los requisitos tributarios de la provisión, pero no los requisitos del castigo; nos preguntamos ¿cuál sería el valor nominal del crédito transferido? En este punto, podemos tener 2 interpretaciones: (i) que el valor nominal como costo tributario del crédito en su transferencia sea igual a cero; o (ii) que el valor nominal sea el que le corresponda al mismo.

A continuación desarrollaremos cada una de estas interpretaciones:

\section{$1^{\circ}$ Que el valor nominal sea igual a cero}

Vale la pena indicar que en el Capítulo II referente a los castigos tributarios, se acogió la interpretación que señala que cuando la Ley regulaba la deducción de incobrables, se estuvo refiriendo a provisiones y castigos directos -en los que no exista una previa 
provisión-. En ambos casos la disminución de la utilidad radicaba en el cargo a resultados de un gasto.

En esta línea de interpretación, el requisito de la provisión previa al castigo introducido por el Reglamento del Impuesto a la Renta, cobra sentido, sólo cuando la provisión no fue aceptada tributariamente y es con el castigo que se permitiría su deducción, toda vez, que con la acción judicial o la constancia de incobrabilidad quedaría demostrada la imposibilidad del recupero no demostrada en la provisión.

En tal sentido, bajo el supuesto que el contribuyente dedujo íntegramente el valor nominal de los créditos (colocaciones y/o cuentas por cobrar) cuando registró la provisión de incobrabilidad, sin necesidad de cumplir con los requisitos del castigo, no resultaría razonable que nuevamente se reconozca el valor nominal del activo financiero al momento en que realice su transferencia, puesto que ello implicaría deducir doblemente el mismo concepto, por lo tanto, el valor nominal sería equivalente a cero.

\section{$2^{\circ}$ Que el valor nominal sea el que le corresponde al mismo.}

No obstante lo anterior, queda claro que cuando el reglamento exige el cumplimiento de ciertos requisitos para el castigo, lo que podría estar buscando es que, a manera de doble filtro, no se pierda el control tributario de las cuentas que lo originan, de tal manera que si en un futuro se procediera con su recuperación se pueda establecer la correlación entre los conceptos que formaron su provisión, esto es, implicaría que el primer filtro sería el que le asiste por su propia naturaleza como provisión del gasto, y el segundo filtro implicaría cumplir con los requisitos del castigo; por ello, su incumplimiento generaría una adición en la declaración jurada por el importe del gasto registrado en un ejercicio anterior. Si posterior a ello, se efectuase la transferencia del crédito castigado el costo tributario del crédito sería el valor nominal que le asiste, el mismo que debería disminuir el ingreso originado por la transferencia.

Considerando el principio de jerarquía de la Ley, la primera posición debería prevalecer, toda vez, que el castigo no sería un requisito de convalidación de la deducción realizada con la provisión de incobrabilidad; no obstante no podemos dejar de lado, que siempre existió la intención de controlar la eliminación de los créditos incobrables a través de los castigos, posición que ha sido validada por el Tribunal Fiscal

y las posteriores modificaciones al Reglamento ( tanto es así que el año 1999, cuando se modificó el Reglamento de la Ley del Impuesto a la Renta, sólo se amplió el plazo para 
la emisión de la Constancia de Irrecuperabilidad para las empresas del sistema financiero).

Por lo expuesto, queda claro que la Administración Tributaria no podría hacer un control de legalidad, inaplicando el Reglamento de Renta al momento de sus fiscalizaciones.

Adicionalmente, debe tenerse en cuenta que la insubsanabilidad de contar con la Constancia de Irrecuperalidad, posterior a la fecha de presentación de la declaración jurada, motiva a un gran sector del sistema financiero a seguir con la política de transferencia de créditos castigados para la recuperación de su valor nominal.

Finalmente, cabe decir que, en nuesta opinión, no se puede interpretar que el incumplimiento de los requisitos de la provisión o del castigo hace que el costo tributario que tendrían las cuentas por cobrar se extinga, ya que esto devendría en una vulneración del principio de capacidad contributiva, por que la norma tributaria no puede desconocer los costos reales incurridos.

Por otro lado, en casos referidos en el literal d), esto es, si no se cumplieron los requisitos tributarios de la provisión, pero se cumplió con obtener la constancia de irrecuperabilidad; el costo tributario del crédito en su posterior transferencia es el valor nominal que le corresponde al mismo. A esta conclusión arribamos ya que a nivel de la LIR no se ha regulado la deducción de castigos para el caso de los supuestos contemplados en el literal h) del artículo $37^{\circ}$ y en consecuencia la obtención de la constancia de irrecuperabilidad no volvería deducible el incobrable así castigado.

En efecto respecto a un activo financiero pueden generarse deducciones tributarias ya sea como gasto o costo. Será un gasto cuando el deterioro por su pérdida de valor hace que se requiera reducir una parte de los ingresos a efectos de mantener la fuente. Si el activo se transfiere lo que se habrá generado es un costo por el valor nominal del mismo neto de las deducciones tributarias que haya experimentado con lo cual se observa el correcto cumplimiento del principio de capacidad contributiva.

En el caso de la empresas del sistema financiero en las que el legislador solo ha contemplado la deducción de provisiones, debe tenerse en cuenta que por el principio general de mantenimiento de la fuente también debería permitirse la deducción de deudas castigadas cuando se ha comprobado efectivamente la imposibilidad de su recupero por haberse agotado los medios judiciales para tal fin. En ese sentido, las 
consecuencias tributarias de las transferencias de créditos castigados serían las mismas que en el caso de deudas de cobranza dudosa.

En todo caso de lege ferenda convendría que el legislador establezca una regulación expresa sobre el efecto de los castigos en el valor nominal de los créditos transferidos, toda vez que, no se tiene claro el papel que ocupa dentro de la regulación del impuesto a la renta, ni las consecuencias directas de su incumplimiento. 


\section{CONCLUSIONES}

- Un activo financiero tal como un crédito y otras cuentas por cobrar constituyen una fuente productora de renta bajo la teoría de renta producto acogida en nuestra legislación. Por lo tanto, las pérdidas por la irrecuperabilidad de los créditos se admiten como gasto pues se acepta que parte de los beneficios que obtiene una empresa se destinen al mantenimiento de la fuente (el capital) que de otra forma se extinguiría irremediablemente.

- Cuando se transfieren activos financieros, el rendimiento obtenido de dicha operación constituye renta imponible bajo la teoría del flujo de riqueza. En este tipo de operaciones es necesario deducir el costo computable de tales activos a efectos de respetar el correcto cumplimiento del principio de capacidad contributiva, esto es tributar por el beneficio neto obtenido.

- El TUO de la Ley del Impuesto a la Renta (en adelante la LIR), establece una regulación expresa para que las empresas del sistema financiero puedan deducir, para efectos tributarios, el gasto originado por el deterioro de sus activos financieros (créditos y cuentas por cobrar) a través de provisiones bancarias y de cobranza dudosa, siempre y cuando cumplan con los requisitos especificados en los incisos h) e i) del artículo $37^{\circ}$ de la LIR respectivamente. Por lo tanto, la provisión de deudas incobrables por créditos constituye una de las provisiones admitidas por la LIR, estando sujeta su deducción tributaria al cumplimiento de los requisitos establecidos en la norma.

- La provisión de créditos y de cobranza dudosa origina que, tanto para efectos contables como tributarios, lo que se generó es un gasto que reduce la renta neta imponible y un descuento al valor nominal de dichos créditos, con lo cual, en el caso de activos íntegramente provisionados que cumplan con los requisitos establecidos en el inciso h) e i) del artículo $37^{\circ}$ de la LIR, el costo del activo financiero equivaldría a cero en el ejercicio en que se realiza la provisión.

- El TUO de la LIR en la determinación del referido impuesto también permite como concepto deducible la deducción de los castigos por deudas de cobranza dudosa 
(literal i. del artículo 37 del TUO de la LIR). No obstante de acuerdo a lo regulado en el Reglamento del Impuesto a la Renta el castigo no sería un concepto deducible per se sino más bien un mecanismo de control fiscal de las cuentas por cobrar previamente provisionadas que ya fueron objeto de deducción en ejercicios pasados, a manera de un segundo filtro de la deducción del incobrable (el primer filtro se habría dado al momento de la provisión). El incumplimiento de los requisitos del castigo tendría como consecuencia una adición en la declaración jurada anual del impuesto a la renta. El efecto antes referido también se ha extendido vía reglamento a las provisiones por créditos bancarios regulados en el inciso h) del TUO de la LIR.

- Ahora bien debe tenerse en cuenta que en materia de incobrables inicialmente se regulaba la deducción de una reserva para malas deudas (inciso d. del artículo $20^{\circ}$ de la Ley $\mathrm{N}^{\mathrm{o}}$ 7904) siendo que jurisprudencialmente se aceptó también la deducción de castigos directos sin que previamente se haya efectuado una reserva (RTF $\mathrm{N}^{\circ}$ 521-1964 y 3677-1968). Posteriormente la nueva Ley del Impuesto a la Renta de 1968, aprobada mediante D.S. N 378-1968-EF reguló expresamente la deducción de castigos siendo en esta época que surge reglamentariamente la provisión como requisito previo al castigo. Jurisprudencialmente en esta época también se aceptó la deducción de provisiones por equipararlas al término "previsiones" (RTF N ${ }^{\circ} 10950$ 1975, 15777-1980 y 23304-1990). Finalmente con el Decreto Legislativo $\mathrm{N}^{\circ} 200$ de 1982 y su reglamento, en una regulación que a groso modo nos acompaña hasta hoy, se reguló expresamente la deducción de provisiones y castigos. De ello podemos inferir que la deducción de castigos para efectos del impuesto a la renta tuvo como origen la aceptación jurisprudencial de los "castigos directos" como deducibles.

- Ello dió lugar a que el legislador introduzca el término "castigos" dentro de la Ley del Impuesto a la Renta. No obstante el reglamentador, a fin de no perder el control tributario de estas deducciones, introduce la provisión detallada como requisito previo de la deducción de castigos. Posteriormente se regula expresamente la deducción de las provisiones pero al hacerlo el reglamentador no modifica la regulación en torno a los castigos que continúan teniendo como requisito previo a su deducibilidad la constitución de provisiones y que conlleva a las múltiples lecturas que se puede dar en torno al rol de los castigos en la actualidad. 
- En la actualidad existen dos problemáticas, (i) la mala o desfasada técnica legislativa que recoge la Ley del Impuesto a la Renta, que califica a los castigos por créditos incobrables como gastos susceptibles de ser deducidos para efectos de la determinación de la renta neta imponible, en la medida, claro está, que se cumplan con los requisitos exigidos en la norma; y, (ii) la teoría de que los gastos por provisiones de crédito y de cobranza dudosa tendrían que pasar por un doble filtro para efectos de su deducción, el primero que le asiste por su propia naturaleza como provisión del gasto, y el segundo que implica cumplir con los requisitos del castigo.

- En relación a la primera problemática, la interpretación más acorde con el contexto histórico y doctrinario es la que se refiere a la posibilidad de deducción de provisiones y castigos cuando estos castigos son directos. No obstante, dado que actualmente siempre se podrán cumplir los requisitos de la provisión previa al castigo en la práctica resulta que el castigo directo, como un concepto deducible del impuesto, ha quedado desfasado siendo que debe ser la provisión y no el castigo lo que resulte deducible.

- Sobre la segunda problemática se tiene que, si una empresa cumpliera con todos los requisitos exigidos en la Ley y Reglamento de Renta para la deducción de la provisión del gasto -el llamado primer filtro-, pero, a su vez no lograra cumplir con los requisitos exigidos para el castigo -el llamado segundo filtro-, la consecuencia tributaria sería, la adición vía declaración jurada anual, del importe correspondiente al gasto por concepto de provisiones para créditos y cobranza dudosa, el mismo que fue deducido legalmente en un ejercicio previo. Si posterior a ello, se efectuará la transferencia del crédito castigado el costo tributario del referido crédito sería el valor nominal que le corresponde al mismo, el cual debería disminuir el valor de su transferencia.

- Bajo el supuesto que el contribuyente dedujo íntegramente el valor nominal de los créditos (colocaciones y/o cuentas por cobrar) cuando registró la provisión de incobrabilidad, sin necesidad de cumplir con los requisitos del castigo, no resultaría razonable que nuevamente se reconozca el valor nominal del activo financiero al momento en que realice su transferencia, puesto que ello implicaría deducir doblemente el mismo concepto, por lo tanto, el valor nominal sería equivalente a cero. 
- En todo caso de lege ferenda convendría que el legislador establezca, una regulación que prescinda de los términos contables de provisión y castigo a la hora de regular la deducción de incobrables limitándose a establecer las causales y los requisitos para su procedencia como concepto deducible del impuesto. En este contexto el contribuyente evaluaría si cumplió dichos requisitos y procedería a la deducción del incobrable con independencia de si contablemente la deuda se encuentra en estado de provisionada o castigada. De mantenerse el uso de los términos de provisión y castigo, se requiere una regulación expresa a nivel de ley sobre el efecto del castigo en el valor nominal de los créditos transferidos, toda vez que, no se tiene claro el papel que ocupa dentro de la regulación del impuesto a la renta, ni las consecuencias directas de su incumplimiento. 


\section{REFERENCIAS}

Abanto Bromley, M., Castillo Chihuan, J., Bobadilla la Madrid, M., Agapito

Custodio, R., Romero Araníbar, C., Paredes Espinoza, B.(2012) Diccionario

Aplicativo para Contadores ( $1^{a}$ ed.). Lima - Perú: Editorial Gaceta Jurídica.

Actualidad Empresarial (2013). Provisión de Cobranza Dudosa. Recuperado de http://aempresarial.com/web/libros_virtuales/lv2013_cobranza_dudosa/lv20 13_cobranza_dudosa.pdf

Bouroncle Maldonado, L. (2010). Castigos del Sistema Financiero. Libro Homenaje a Luis Hernandez Berenguel,. Lima: Instituto Peruano de DerechoTributario.

Bravo Cucci, J. (2002) Tema II: Implicancia de las NICs en la aplicación del Impuesto a la Renta. VII Jornadas Nacionales de Tributación. Recuperado de http://www.ifaperu.org/uploads/articles/8_03_CT28_JABC.pdf

Capuñay, M. (1963). Actualización y concordancia de la Ley 7904 y reglamentos. Lima Perú: Editorial Guion.Cabanellas, G. (1989) Diccionario Enciclopédico de Derecho Usual. Tomo II (21 a ed.). Buenos Aires Argentina: Editorial Heliasta S.R:L.

García Mullín, R. (1980) Manual del Impuesto sobre la Renta. Santo Domingo: Centro Interamericano de Estudios Tributarios.

García Belsunce, H. (1967) El concepto de rédito en la doctrina y en el derecho tributario. Buenos Aires, Argentina: Editorial De Palma.

Ramírez-Gastón, R. y Ramírez-Gastón, A. (2008) X Jornadas Nacionales de Derecho Tributario: Implicancias Tributarias en el Impuesto a la Renta de la Cesión de un Crédito a favor de un Sujeto No Domiciliado. Lima, Perú: Insttituto Peruano de Derecho Tributario.

Reig, J.(1972). Impuesto a los réditos (6 ${ }^{a}$ ed.). Buenos Aires- Argentina: Ediciones Contabilidad Moderna.Picón Gonzales, J. (2004) Deducciones del Impuesto a la Renta Empresarial ¿Quién se llevó mi gasto? La Ley, la Sunat o lo perdí yo, Código 55 SAC.

Rubio Guerrero, J.(2001) Los principios básicos de la fiscalidad internacional y la doble imposición internacional. Manual de Fiscalidad Internacional. Instituto de Estudios Fiscales.

Rubio Correa, M. (2009) El sistema Jurídico Introducción al Derecho (10 ${ }^{a}$ ed). Lima - Perú: Fondo Editorial de la PUCP. 


\section{BIBLIOGRAFÍA}

Avila, H. B., \& Criado, S. L. (2012). Teoría de la seguridad jurídica. Madrid: Marcial Pons.

Barchi, L. (2000-2001), Revista del Magister en Derecho Civil. Volumen 4-5. PUCP.

Elías Laroza, E. (1999), Derecho societario peruano: la Ley General de Sociedades. Lima: Normas Legales.

Colín, A. y Capitán, H. (1923). Curso Elemental del Derecho Civil. Tomo Segundo, Volumen II. Madrid, Reus.

García Mullín, R. (1980) Impuesto sobre la Renta. Santo Domingo: Centro Interamericano de Estudios Tributarios, 1980.

García Novoa, C. (2000) El principio de seguridad jurídica en materia tributaria. Madrid : Marcial Pons.

Giuliani Fonrouge, C. M. y Navarrine, S. (1980) Impuesto a las Ganancias. Análisis de Doctrina y Jurisprudencia. Ediciones Depalma. Buenos Aires.

Jarach, D. (1980). Impuesto a las Ganancias. Editorial Cangallo. S.A.C.I. Argentina.

Jarach, D. (1983) Finanzas Públicas y Derecho Tributario. Buenos Aires: Abeledo Perrot.

Lafaille Hector (1984) Tratado de los Derechos Reales, Volumen I. Buenos Aires, 1984.

Libro Homenaje a Hernandez Berenguel, L (2010). Lima. Instituto Peruano de DerechoTributario.

Martin Queralt, J., Lozano Serrano, C., Tejerizo López, J. y Casado Ollero, G. (2013). Curso de Derecho Financiero y Tributario. Madrid: Editorial Tecnos. $24^{\mathrm{a}}$ edición.

Osterling Parodi, F. y Castillo Freyre, M. (1994) Tratado de las Obligaciones. Tomo III. Lima: Fondo Editorial de la Pontificia Universidad Católica del Perú.

Parra Escobar, A. (2007). Planeación tributaria y organización empresarial: Estrategias y objetivos. Bogotá: Legis Editores.

Pérez de Ayala, J. L. (2005). Explicación Técnica de los Impuestos. Editorial de Derechos Financieros. $3^{\circ}$ Edición.

Pérez de Ayala, J. L. (1970) Las ficciones en el Derecho Tributario. Madrid: Editorial del Derecho Financiero. 
Reig, J. (1972) Impuesto a los réditos. Buenos Aires : Ediciones Contabilidad Moderna. 6ta.cd. 1972. Cap. I.

Rubio Correa, M. (2009). El sistema jurídico: Introducción al Derecho. Lima : PUCP. Fondo Editorial

Saavedra, O. J. J., Serrano, A. A., \& Carnero, P. D. (2011). Operaciones mercantiles y productos de inversión en los mercados financieros. Barcelona: Bosch.

Vásquez Ríos, A. (1994). Los derechos Reales - La propiedad. Lima: Jus. Editores.

V. Alle Sanchez, V. (1970). El Impuesto sobre la renta de sociedades. Madrid, 1970.

Villanueva Gutierrez, W. (2014). Tratado del IGV, Regímenes General y Especiales. Lima, Perú. Instituto Pacífico S.A.C.

Villegas, Hector (2002). Curso de finanzas, derecho financiero y tributario. Buenos Aires: Editorial Astrea. $4^{\mathrm{a}}$ edición. 